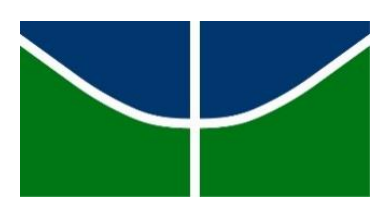

UNIVERSIDADE DE BRASÍLIA - UNB

INSTITUTO DE CIÊNCIAS SOCIAIS - ICS

DEPARTAMENTO DE ANTROPOLOGIA - DAN

PROGRAMA DE PÓS-GRADUAÇÃO EM ANTROPOLOGIA SOCIAL -PPGAS

BÁRBARA DUARTE DE SOUZA

NA CASA E NO MERCADO

TROCAS E MORALIDADES NA REPRODUÇÃO

DA COLÔNIA PALESTINA EM MANAUS

BRASÍLIA

2015 


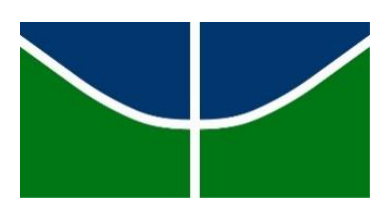

UNIVERSIDADE DE BRASÍLIA - UNB

INSTITUTO DE CIÊNCIAS SOCIAIS - ICS

DEPARTAMENTO DE ANTROPOLOGIA - DAN

PROGRAMA DE PÓS-GRADUAÇÃO EM ANTROPOLOGIA SOCIAL -PPGAS

BÁRBARA DUARTE DE SOUZA

NA CASA E NO MERCADO

TROCAS E MORALIDADES NA REPRODUÇÃO

DA COLÔNIA PALESTINA EM MANAUS

Dissertação de mestrado apresentada ao Programa de Pós-Graduação em Antropologia Social do Departamento de Antropologia da Universidade de Brasília, como requisito para obtenção do título de Mestre em Antropologia Social.

Orientador: Dr ${ }^{\mathrm{a}}$ Kelly Cristiane da Silva

BRASÍLIA 


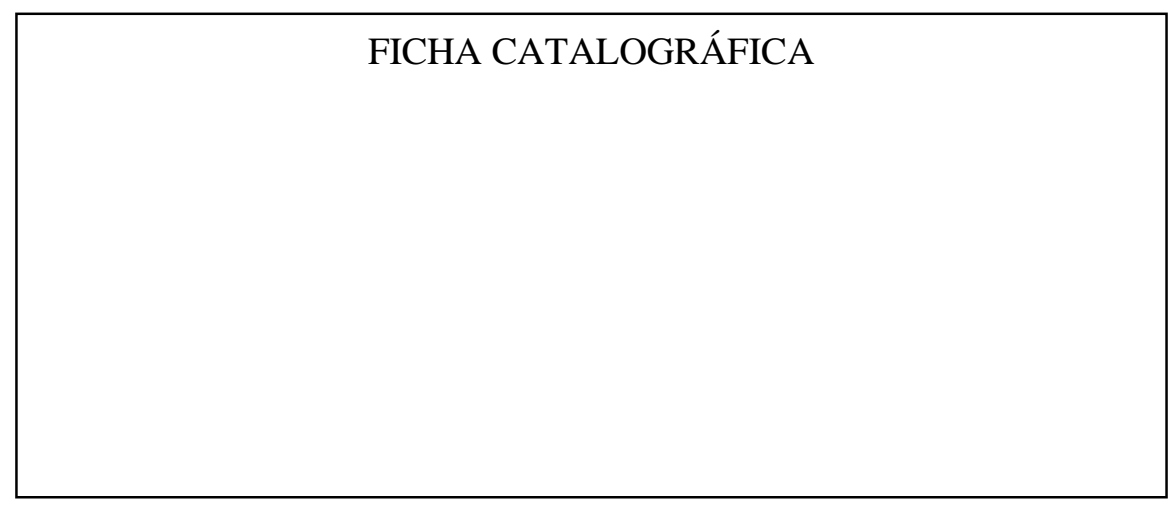




\section{NA CASA E NO MERCADO \\ TROCAS E MORALIDADES NA REPRODUÇÃO \\ DA COLÔNIA PALESTINA EM MANAUS}

Dissertação de mestrado apresentada ao Programa de Pós-Graduação em Antropologia Social do Departamento de Antropologia da Universidade de Brasília, como requisito para obtenção do título de Mestre em Antropologia Social.:

\section{Data de aprovação:}

\section{Conceito:}

\section{Banca Examinadora:}

Dra. Kelly Cristiane da Silva (orientadora) - DAN/UnB

Dra. Denise Fagundes Jardim - PPGAS/UFRGS

Dra. Kelly Cristiane da Silva (orientadora) - DAN/UnB

Dra. Sonia Cristina Hamid - IFB 
À mamãe e papai. Graças aos seus dias de suor, de renúncia e de emoções contidas. Ofereço-lhes este resultado como tributo de uma dívida incalculável, que não pode e nem quer ser paga.

$$
\text { [...] }
$$

Para Samir, com o reconhecimento profundo do amor cristalino feito cajuína.

$$
\text { [...] }
$$

Em memória à casa que repousa no íntimo de cada um. 


\section{AGRADECIMENTOS}

Em verdade, essa dissertação é resultado de muitas coisas, coisas que nem eu consigo compreender ou sentir. Só consigo entender que o trabalho de minha mente, das minhas mãos, e de todo o meu corpo envolvido nesta empreitada, se deve indiscutivelmente e primeiramente à minha família. Minha mãe, meu pai e minha irmã, que moram na casa que repousa dentro de mim! Agradeço também aos meus primos e primas, tios e tias, avôs e avós, que me possibilitam uma vida plena de afetos e amor!

Também devo à oportunidade de ingresso no Programa de Pós-Graduação em Antropologia Social da UnB, é claro! E especialmente às pessoas que direta ou indiretamente possibilitaram a continuidade de minha formação: à Cris, ao Jorge, à Rosa, à Branca, sempre tão solícitos. Ao CNPq pelo apoio material tão indispensável.

Ao corpo docente do Departamento de Antropologia, especialmente aos professores Daniel Simião, Marcela Coelho e Antonádia Borges pelas aulas preciosas, que me ajudaram a expandir muitas possibilidades por mim desconhecidas. Ao professor Albert Farré pelas horas de aprendizados importantíssimos para a conformação do pensamento registrado nestas páginas!

Aproveito para agradecer ao professor Marcelo Carvalho da Universidade Federal do Amazonas, pela estímulo e contribuição para que esse projeto tivesse êxito. E aos professores Romero Ximenes e Francrosy, muito obrigada pela orientação no pontapé inicial. Essa culminância também se deve a vocês.

Devo muito também à minha orientadora Kelly Silva, pela leitura percuciente de meus rascunhos vacilantes e imprecisos. Muito obrigada pela paciência, pelo interesse e por insistir no melhor que eu pudesse dar, me conduzindo na minha primeira experimentação adulta na antropologia.

E como não falar das pessoas a quem mais devo? Definitivamente, eu nunca poderia inventar sujeitos tão especiais e particulares como os que conheci em Manaus! O meu muito obrigada acompanhado de pedidos de desculpas, como as desculpas de quem sai da casa do anfitrião por achar ter incomodado. Muito obrigada pela paciência, pelo acolhimento, pela irreverência e pelo muito que aprendi! 
Aproveito para lembrar da minha turma de mestrado, cuja composição rendeu riquíssimas discussões e debates construtivos. Muito obrigada pelos momentos de descontração, pela disposição em ouvir e em estar. Valeu Jú Miras e Jú Arcanjo, Jana, Raoni, Mari, João, Bel Ibiapina, Ariel, Bruno, Edson, Natália e Kris pelo conforto das horas complicadas com um tipo Lévi-Strauss!

Aproveito para lembrar do espaço katacumbeiro, do acolhimento e simpatias revigorantes da Leidi, da Jú Sakamoto, do Brunner, da Chirley, Sandro, do Jose e do Alê! Muito obrigada por existirem e serem tão loucos aspirantes a antropólogo!

E como não lembrar da simpatia da Sônia, da sua serenidade diante das preocupações hodiernas da vida dos pesquisadores profissionais. Muito obrigada pela disposição para compartilhar, para dividir saberes, experiências, pensamentos e impressões que muitos só dão a preço de ouro! Para estas trocas também devo à Chirley e à Jú Miras, a quem envio especiais agradecimentos.

Não posso encerrar estes agradecimentos sem lembrar dos amigos que construí nos lugares que habitei em Brasília e em Manaus: Samille, Mariana, Luiz, Vitória e Kamille! Muito obrigada por não me fazerem esquecer que eu sempre posso voltar pra casa.

Agradeço às amigas de sempre e que também são para sempre: Vanessa, Alexandra, Maria Augusta, Ana Carolina e Roberta. Muito obrigada por encarnarem o sentido da fraternidade e do espírito que eu reconheço neste mundo!

Mamãe, papai e Samir, muito obrigada pelas portas escancaradas com que vocês me recebem sempre! E por me ensinarem que devo graças a Deus! 


\section{RESUMO}

Esta dissertação é um esforço etnográfico para identificar os fenômenos elementares geradores da colônia palestina de Manaus. A argumentação que se segue é resultado de uma postura metodológica que pôs em suspensão a noção de colônia, que compõe os discursos dos imigrantes palestinos de Manaus para se referirem ao conjunto de famílias palestinas que vivem naquela cidade. Demonstro que esta colônia não é apenas um conjunto de pessoas que possuem interesses e identificações políticas em comum: ela é um lugar entre o Amazonas e a Palestina, produzido e reproduzido pelos laços persistentes e complementares de sua conformação. A colônia palestina de Manaus é um conjunto de relações que se produzem através de disposições alimentadas sobre moralidades e trocas de recursos materiais, afetivos e simbólicos. A colônia, nesta dissertação, é o efeito de modelos geradores que distribuo espacialmente entre a "casa" e o "mercado", responsáveis por provocar a característica de insularidade destas famílias, que existem num campo social único e dependente do chão de Manaus e do céu da Palestina.

Palavras-chave: Colônia. Imigrantes Palestinos. Dádiva. Manaus. 


\begin{abstract}
This dissertation is an ethnographic effort to identify the elementary phenomena generators of the Palestinian colony of Manaus. The argument that follows is the result of a methodological approach which it has suspended the colony notion, which make up the discourse of Palestinian immigrants from Manaus to refer to the set of Palestinian families who live in that city. This shows that this colony is not just a collection of people who have interests and political identifications in common: it is a place between the Amazonas and Palestine, produced and reproduced by persistent and complementary ties of its conformation. The Palestinian colony of Manaus is a set of relations which are produced through provisions powered about morals and exchange of material resources, affective and symbolic. The colony, of this dissertation, is the effect of generating models that distribute spatially between "home" and the "market", responsible for causing insularity characteristic of these families, which exist only one social field and dependent on the floor of Manaus and the Palestine sky.
\end{abstract}

Keywords: Colony. Palestinian immigrants. Gift. Manaus. 


\section{LISTA DE ILUSTRAÇÕES}

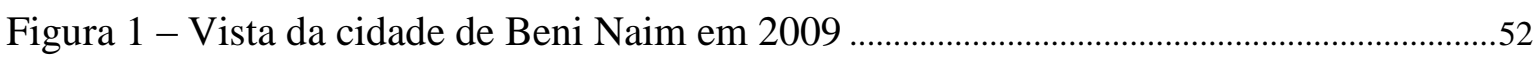

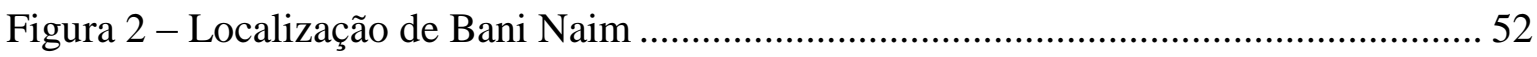

Figura 3 - Plantação e criação de animais em Beni Naim, 2009 ......................................... 53

Figura 4 - Representação hierárquica do sistema de "ajuda"............................................ 84

Figura 5 - Localização da Avenida Marquês de Santa Cruz............................................... 93 


\section{LISTA DE TABELAS}

Tabela 1 - Algumas empresas e pessoas que integram o quadro da Associação Comercial do Amazonas em 1971 46 


\section{LISTA DE ABREVIATURAS E SIGLAS}

$\begin{array}{ll}\text { ANP } & \text { Autoridade Nacional Palestina (ANP) } \\ \text { CONARE } & \text { Comitê Nacional para os Refugiados } \\ \text { DEM } & \text { Democratas } \\ \text { FIEAM } & \text { Federação das Indústrias do Estado do Amazonas } \\ \text { MOPAT } & \text { Movimento Palestina para Tod@ s } \\ \text { OLP } & \text { Organização pela Libertação da Palestina } \\ \text { ONU } & \text { Organização das Nações Unidas } \\ \text { PEC } & \text { Proposta de Emenda à Constituição } \\ \text { PMD } & \text { Partido do Movimento Democrático o Brasil } \\ \text { PSD } & \text { Partido Social Democrático } \\ \text { PSDB } & \text { Partido da Social Democracia Brasileira } \\ \text { PT } & \text { Partido dos Trabalhadores } \\ \text { SUFRAMA } & \text { Superintendência da Zona Franca de Manaus } \\ \text { ZFM } & \text { Zona Franca de Manaus }\end{array}$




\section{SUMÁRIO}

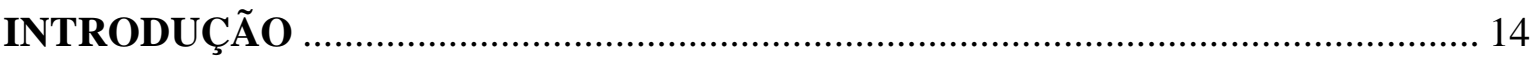

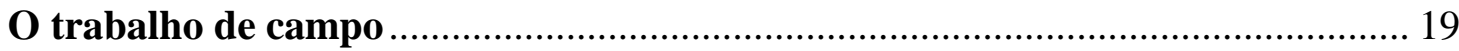

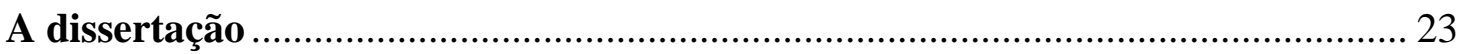

\section{CAPÍTULO 1 - A FORMAÇÃO DE UMA "COLÔNIA PALESTINA"} EM MANAUS: PERFORMANCES LABORAIS E CONDICIONANTES HISTÓRICOS

1.1 Panorama dos estudos sobre palestinos no Brasil: contextos e escolhas interpretativas ........................................................... 26

1.2 Ensaio sobre a imigração árabe no Brasil:

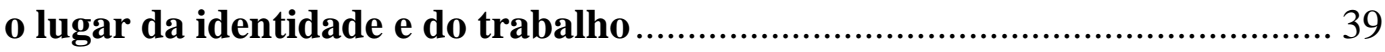

$1.3 \mathrm{O}$ ciclo econômico em Manaus na época dos mascates palestinos ……........... 43

1.4 A que se deve o sucesso? Questões em torno das narrativas de acomodação e da produção da "colônia"

1.5 Por que mascatear? A família bilocal é uma rede com efeitos de reprodução do mascate e da colônia

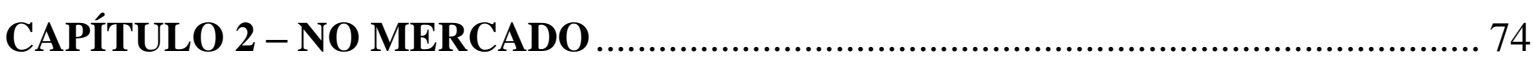

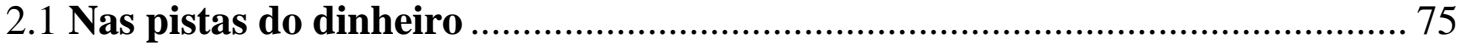

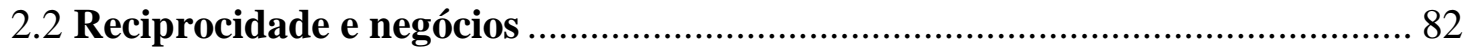

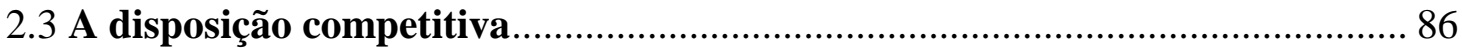

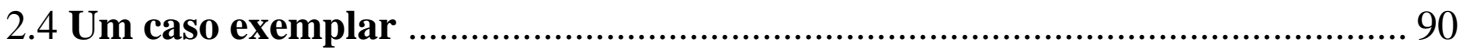

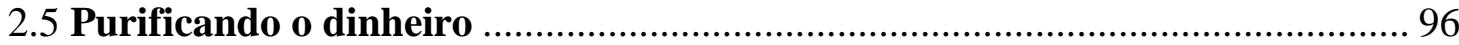

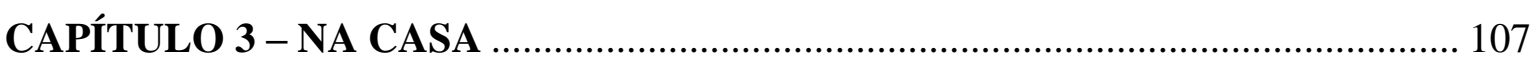

3.1 Algumas considerações sobre honra .............................................................. 108

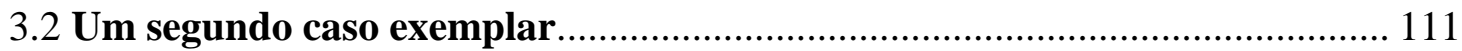

3.3 Com quem interessa casar. O que interessa ser ........................................ 125

3.4 Evidências da família bilocal .................................................................... 133

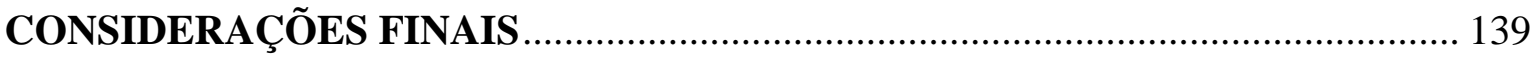

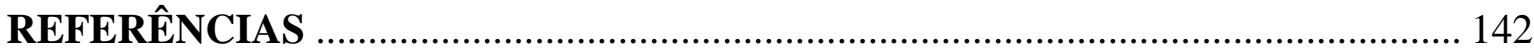




\section{INTRODUÇÃO}

"Uma cidade não é a mesma cidade se vista de longe, da água: não é sequer cidade: falta-lhe perspectiva, profundidade, traçado, e sobretudo presença humana, o espaço vivo da cidade. Talvez seja um plano, uma rampa, ou vários planos e rampas que formam ângulos imprecisos com a superfície aquática"

Hatoum, Milton. 2008. Relato de um certo oriente.

No espaço público manauara, a representação da colônia palestina que habita a localidade tem sido atribuída à instituição denominada "Sociedade Árabe-Palestina", fundada na década de 1970. A Sociedade foi criada para reunir os chefes das famílias em assuntos que diziam respeito à Palestina, momentos em que ordinariamente eram discutidos os meios e os recursos para atender às necessidades de infraestrutura e auxílio para a reconstrução das regiões em conflito. Mas o termo "colônia” já era utilizado, e parecia remeter à convivialidade cotidiana e intensa dos palestinos de então, cuja maioria era proveniente da cidade de Beni Naim, um vilarejo próximo à província de Hebron, na Cisjordânia.

No início, a "colônia" para mim expressava um ideal abstrato de organização destas pessoas, como uma entidade ou marca periodicamente acionada nos casos em que importava afirmar-se enquanto palestinos. Para marcar este sentido, que de fato observo quando meus interlocutores refletem ou fazem uso desta denominação para construir diferenças, eu opto pela utilização das aspas. Mas como o meu movimento foi o de investigar os sentidos desta denominação, assumindo que ela é efeito de relações e de trocas, considero que a colônia pode ser captada ou observada. Nestes casos eu não uso aspas para indicar que ela tem repercussão nas ações que problematizo, que ela é a relação dos sujeitos representados nesta pesquisa.

A opção por fazer da colônia o objeto desta dissertação poderia não ter durado caso eu constatasse que atualmente o único conteúdo amalgamador destas pessoas dissesse respeito aos interesses políticos ligados à sustentação da ideia de um "povo palestino". Tais interesses evocam um senso de responsabilidade para com a manutenção de condições de sobrevivência dos palestinos que ainda vivem naquele território, bem como a uma ideologia nacional que os vinculam àquele lugar. Se a única afinidade destas pessoas fosse esta, a participação de 
eventos de ativação cultural e de deliberação de interesses coletivos, possivelmente eu não conseguiria escrever mais de cem páginas sobre a colônia.

Se os sujeitos com quem cruzei, os meus interlocutores voluntários e involuntários, só tivessem essa afinidade em comum, eles pareceriam comigo e com milhares de outras pessoas. Logo que eu cheguei em campo eu pensava mais ou menos assim, só que percebi a tempo que isso não poderia render um argumento convincente para uma dissertação em antropologia. $\mathrm{O}$ meu olhar sobre o campo estava orientado pelas leituras prévias sobre os palestinos no Brasil e alguns trabalhos sobre os palestinos no mundo, sobre parte da literatura sobre imigrantes e, principalmente, pelo segmento clássico da antropologia interessado em questões de grupo.

Estava eu, portanto, à procura de um grupo, com um modo de vida específico, práticas, comportamentos e metas igualmente específicos e delineáveis do ponto de vista da etnicidade. Mas essa visão foi se dissolvendo a medida em que conhecia as pessoas e construía relações com meus interlocutores. O espaço do contraste, da diferença, ficava mais obscuro e profundo, em níveis que demorei um pouco para alcançar. Se os alcancei foi porque aprendi a construir as diferenças sobre outras bases, à maneira da produção de fatos etnográficos, tal como abordada por autores como Malinowski (1978) e Evans-Pritchard (1978), por exemplo. Entre outras coisas, ambos nos alertam para a necessidade de explicitação do processo de construção de um objeto de pesquisa, indicando que a origem primeira de tal fenômeno encontra-se dentro do antropólogo (PEIRANO, 2008).

Com o crescimento da consciência das condições formativa, psicológica e emocional em que eu investigava, pude perceber melhor qual caminho adotar e quais caminhos abandonar para elaborar o meu objeto e a sua interpretação, o meu problema e sua solução. Creio que meu encanto pelos palestinos que lutam em uníssono pelo justo reconhecimento de suas terras já havia sido parcialmente quebrado por um ensaio etnográfico que realizei junto a universitários palestinos na Itália entre os anos de 2010 e 2011. Naquela ocasião quis avaliar as interações desses estudantes e suas consequências para o mundo moral e representacional que evocavam como sendo genuinamente "palestino". Os palestinos de "carne e osso" e a realidade perceptível em Manaus também contribuíram para uma relação mais crua com os universos que estes sujeitos me permitiam entrever.

Por estas razões acreditei poder cumprir com as exigências que uma produção em Antropologia Social requer, ao me esforçar em procurar as causas para as relações analisadas nas prefigurações que estes sujeitos escolhem e se associam, e não em ideias abstratas como "cultura", "sociedade" e "religião". Para o campo dos "palestinos no Brasil” me julguei apta, 
embora minha inserção não estivesse ainda bem resolvida. O que mais me incomodava era o fato de não possuir amizades que me levassem "naturalmente" (se é que a intenção de pesquisa possibilita incursões desinteressadas) aos meus interlocutores, em circunstâncias livres de constrangimentos, medos ou receios.

Quanto à inserção mal resolvida, acho que consegui lidar com seus efeitos pois, por mais estranha que eu me pareça com relação ao objeto de análise, uma fala sobre o outro nunca deve pretender o controle científico e mesmo político no estabelecimento de relações. Assim sendo, se a validação e produção de consenso sobre o que suponho corresponder ao comportamento ou evento observado fossem os objetivos desta dissertação, a identificação com o objeto estudado certamente não seria um desses critérios. Com isto, me apoio nas metarreflexões sobre a crise de representação na escrita etnográfica, que tem como preocupação analítica central os tons discursivos e as estratégias utilizadas para descrever as relações com outras pessoas, que é comprometida com uma doutrina da parcialidade e fluxo e que até as situações individuais são instáveis (RABINOW, 2002).

Agora que o problema da "inserção" em campo foi esclarecido, passo para as indagações acerca do que referi como sendo as "prefigurações que estes sujeitos escolhem e se associam". As metas de "grupo" pareciam bem claras desde o início, aquelas metas organizadas em nome da "colônia" e que produziam efeitos públicos e políticos. Mas qual o valor dessas metas? Quais os sentidos que estas práticas evocam entre seus pares e para os não palestinos? A partir das evidências contadas pelos próprios interlocutores de que são pessoas distintas da sociedade envolvente (no nível de afirmação da palestinidade e de arabização), o meu interesse não era o de marcar efeitos de globalização na vida destas pessoas como para explicar compartilhamentos e transformações do self, mas o de entender como é possível sua reprodução enquanto palestinos e quais os sentidos disso.

A busca pelos sentidos de certas práticas me revelava construções acerca do modo de existir, e estas construções repetidas ou normativas me davam um certo critério de afinidade, de pertencimento, um chão. Deste modo, observei critérios de pertencimento, embora bastante moldáveis e aparentemente contraditórios que me conferiam certo alívio ao pretender discutir sobre "palestinos". Depois de achar ter resolvido a definição do objeto, a "colônia", eu descobri que primeiramente eu deveria entender que definição era esta. O fato é que a "colônia" existia desde a chegada dos primeiros imigrantes, na década de 1960, e continuava a existir em 2014, mas em quais condições? As mais de cem páginas que constituem esta 
dissertação são um esforço de apreender e compreender algumas das dinâmicas de produção e reprodução da colônia palestina de Manaus.

Para tanto, faço uso dos enquadramentos sugeridos pela bibliografia especializada e das informações produzidas em campo. Como primeira medida epistemológica neste exercício, coloco em suspensão a ideia de "colônia", para capturar os mecanismos elementares pelos quais a colônia emerge enquanto tal. Sou fortemente inspirada pelas considerações de Wolfe (1978), quando constrói uma espécie de genealogia da abordagem das redes sociais. Este autor identifica que a metáfora da "rede" na abordagem antropológica é produto de um processo de tendências que já figuravam em alguns estudos, como o fato de se priorizar as relações ao invés das coisas, os processos ao invés das formas, os fenômenos elementares ao invés de instituições e a construção de modelos geradores ao invés de modelos funcionais.

Inspirada por esta perspectiva, busco apreender as disposições elementares de produção da colônia, ou, em outras palavras, as condições embrionárias de sua produção. Esforço-me para demonstrar que elas se encontram nas transações e ativações de fluxos, discursos, narrativas, compromissos, dívidas etc. Os fatos elementares são os mecanismos de troca e, neste sentido, recorro a preceitos analíticos da antropologia econômica, como os regimes de troca, a fim de compreender o que eles produzem. A existência de trocas, orientadas por regimes específicos a depender do contexto, permite a produção e reprodução da colônia palestina. Neste quadro, o casamento emerge como forma de troca fundamental.

Destaco também que os mecanismos de troca são produzidos no que denomino como espaço doméstico e espaço público, e suas modelagens se dão a partir de elementos transversais relativos aos fatores de notoriedade, ao sentimento de vergonha, à honra, à respeitabilidade, e aos papéis de gênero. Identifico basicamente dois grandes mecanismos para a produção e reprodução da colônia: o modelo de empresa familiar mantido pelas práticas de recrutamento dos funcionários dentro da própria família, e as estratégias matrimoniais e de conformação das subjetividades das mulheres.

Uso a distinção entre "espaço doméstico" e "espaço público" para demonstrar que as dinâmicas de reprodução da família atende a um ideal compartilhado de "família árabe", cujas dinâmicas são exclusivas e fundamentais para a geração e reprodução da colônia. Feito isto, passo ao exercício de dissolver os limites entre a ideia de produção, reprodução, espaço doméstico e espaço público, na medida em que a colônia é produzida por fenômenos que ocorrem em ambos os espaços, muitas vezes difíceis de delimitar. 
Para marcar a diferença entre o âmbito do mercado e o âmbito da casa, eu construo uma distinção que concebe as "ações comerciais" como aquelas que acontecem no âmbito do mercado ou espaço público, e "ações domésticas" como as que acontecem no âmbito da casa. A proposta de separação é um esforço de análise que objetiva caracterizar duas dimensões vitais de meus interlocutores. A distinção entre "casa" e "mercado" é construída por Gregory (1997), que as entende como formas distintas de consciência na produção de valores sobre coisas, pessoas e relações. Tais ações são, como se verá, muito difíceis de serem circunscritas, uma vez que seus sentidos são combinados por valores das duas esferas. Dito isto, reconheço que as ações comerciais podem carregar sentidos pertinentes à lógica de "mercado", mas o que destaco são os momentos em que ela corresponde a uma lógica de "casa", quando também passa a ser uma ação doméstica, só que realizada através da atividade comercial.

Por "regimes de troca", tenho em mente a definição sintetizada por Silva (2015b). Para a autora, um regime de troca é uma categoria analítica que tenciona abranger as regras, expectativas e efeitos que qualificam as formas de transações entre pessoas. Silva (2015b), inspirando-se em Appadurai (1986), indica a existência de pelo menos três regimes de troca típicos-ideais: o escambo, o mercado e a dádiva. Cada um destes regimes produz um tipo de relação, sendo que o regime da dádiva é o único a produzir relações duráveis entre pessoas, por meio da permuta de coisas ou mesmo de pessoas, em que a importância recai, sobretudo, na relação entre as partes da troca que, pelas circunstâncias da dádiva, é muitas vezes assimétrica.

A definição de "mercado" e "casa" pode servir tanto para qualificar o espaço onde a troca ocorre como o regime de troca em pauta. No espaço do "mercado" ao qual me refiro como o centro comercial de Manaus ou a Rua Marechal Deodoro, que concentra a maioria de meus interlocutores, predomina a lógica do regime de "escambo" e de "mercado", em que a troca é impessoal, livre das relações entre as pessoas e que pode ser instável e diminuída pela importância que se dá nas coisas trocadas. Mas é importante destacar que os regimes de troca coexistem na dinâmica social, de modo que a presença do dinheiro, por exemplo, não pode por si só indicar qual o regime de troca em pauta. Como explica Silva (2015b): "some transactions may begin as commodity-like operations and be turned into gift exchanges [...] Moreover, one must observe that one single object may circulate through different regimes of exchange throughout its social life" (SILVA, 2015b).

Apesar de reconhecer que tanto no "mercado" como na "casa" o regime da dádiva se faz expressivo, opto pela utilização desta oposição para marcar em quais circunstâncias isto ocorre. Isto é fundamental para a compreensão das ações comerciais que, por se realizarem no 
âmbito do regime de mercado, não quer dizer que sempre apresentam a lógica do mesmo. São "ações comerciais" porque pretendo sublinhar que meus interlocutores estão em ato na atividade comercial propriamente dita, estão trabalhando, agenciando mercadorias e se relacionando com diferentes pessoas. Mas no bojo destas ações comerciais, encontram-se muitas vezes, a meu ver, ações que manifestam uma economia da dádiva.

\section{O trabalho de campo}

A minha própria relação com meus interlocutores se construía basicamente em dois espaços: o do estabelecimento comercial e o das suas residências. Por isso é importante estabelecer um breve perfil destes sujeitos e das circunstâncias de nossas conversas, uma vez que elas definem espacialmente alguns assuntos mais abordados com uns do que com outros. Logo que cheguei a Manaus, para o pré-campo que se deu entre os dias primeiro e quinze de novembro de 2013, me dirigia aos palestinos que trabalhavam na rua Marechal Deodoro, pois ali se concentravam muitas de suas empresas familiares, segundo me dissera o Sr. Omar, meu primeiro interlocutor ${ }^{1}$.

Ao tomar conhecimento do número significativo de palestinos no Amazonas, iniciei uma busca por algum contato que pudesse me levar a algum deles. Uma vez que seus nomes apareciam associados à economia e à política de Manaus nas reportagens veiculadas em jornais virtuais, telefonei para o gabinete do então governador do Amazonas, Omar Aziz ${ }^{2}$, que parecia manter alguma relação com os palestinos ali residentes. Consegui falar com a secretária do gabinete, lhe comuniquei meus interesses de pesquisa e recebi prontamente os dados do $\mathrm{Sr}$. Omar, que, segundo ela, fazia parte do círculo de relações pessoais do governador.

A partir de então comecei a trocar e-mails com o Sr. Omar, lhe comuniquei sobre a minha visita à cidade para dar início à pesquisa e sobre o meu interesse em conversar pessoalmente sobre estes assuntos. $\mathrm{O}$ meu principal interesse naquele momento era o de saber sobre a sua vinda e dos demais, e também o de esclarecer algumas dúvidas que eu tinha em relação à leitura prévia das notícias que circulam na internet a respeito deles, deixando claro que meus objetivos ainda eram indefinidos, pois aquela visita se tratava de uma pesquisa exploratória a ser continuada no próximo ano com uma estadia maior.

\footnotetext{
1 Todos os interlocutores citados receberam nomes fictícios, com a finalidade de preservá-los de quaisquer comprometimentos com os dados produzidos aqui.

2 Omar Aziz é de origem palestina. Nasceu no interior do estado de São Paulo e, posteriormente, migrou para Manaus acompanhando seus pais. Até a data de seu falecimento, o pai de Omar Aziz foi bastante atuante na Sociedade Palestina do Amazonas segundo contam meus interlocutores.
} 
Assim foi o início de meus contatos com estas pessoas que, para fins didáticos e de compreensão, organizo da seguinte forma: o primeiro bloco de interlocutores é o dos representantes ou ex-representantes da sociedade, dentre os quais destaco Farid e Cid, que se dispuseram mais vezes e por mais tempo a me receber, de modo que pude entender mais o lugar que eles ocupam. Ambos têm por volta de 70 anos de idade, chegaram em Manaus no final da década de 1960 e possuem um vasto patrimônio ramificado entre suas respectivas descendências e sócios. Definiria o Segundo bloco de interlocutores como os que estão entre 40 e 50 anos de idade, são filhos ou sobrinhos dos primeiros imigrantes e também usufruem de confortável situação econômica, principalmente Omar, seguramente o mais rico de todos, atrás apenas do sogro, Osmar.

Além de Omar, neste segundo bloco incluo Fauzi, Fuad, Jamal e Youssef, todos atuantes na Marechal Deodoro e compartes de uma imbrincada relação de parentesco. Importante notar que não pude ter contato com suas respectivas esposas, principalmente porque não havia ocasião para tal, uma vez que eu não as encontrava no comércio e não era convidada para visitá-las em suas casas. Algumas estavam na Palestina no meu período em campo, e mesmo frequentando as orações nas sextas-feiras, eu nunca presenciei as mulheres que estavam em Manaus naquele espaço, com exceção dos domingos do mês do Ramadã que se deu no meu último mês em campo, quando conheci a esposa de Fuad e uma cunhada de Youssef.

Já no terceiro bloco reúno as pessoas que conheci em um último momento de campo, depois de já haver tido conhecimento de parte das dinâmicas no espaço comercial da cidade. Este grupo de interlocutores foi formado com o meu início nas aulas de árabe, ministradas por Ranya para os nascidos no Brasil de pai ou mãe imigrantes palestinos ou muçulmanos brasileiros interessados na língua. $\mathrm{O}$ curso era aberto ao público, e foi indicado a mim por Farid como oportunidade para conhecer Ranya que, segundo ele, me facilitaria a compreensão para muitos assuntos relativos à "cultura palestina".

Este grupo é muito variado, mas possui uma qualidade em comum que é a de pertencer às classes medias. Além de Ranya que deve ter por volta de 35 anos, conheci as famílias das senhoras Graça e Carmem, brasileiras casadas com imigrantes palestinos. Estas senhoras têm entre 55 e 60 anos, e frequentavam as aulas com alguns de seus netos e noras. Por intermédio das duas, tive alguns contatos com seus filhos, que em geral não se sentiam à vontade para tratar de temas relativos ao comércio e à família, embora me vissem na companhia de suas mães. Apenas um dos filhos de Carmem ficou mais interessado pelas minhas questões, e 
mesmo seu pai, o Sr. Nasser, do qual consegui considerações preciosas, não queria comentar tais assuntos porque segundo ele, "não queria falar mal dos palestinos de Beni Naim".

Finalmente considerarei três outros interlocutores brasileiros: o senhor Sandro e as senhoras Fátima e Verônica que devem estar na faixa dos 40 a 60 anos. O primeiro é conhecedor do movimento comercial do centro da cidade, e possui relações próximas com os atuantes na Marechal Deodoro. Fátima foi o único caso encontrado por mim de alguém que tenha se divorciado de um palestino e, sabendo do meu interesse em pesquisar sobre a colônia, se prontificou a me conceder algumas horas para compartilhar suas impressões e experiências. E Verônica é a proprietária do apartamento que eu alugava, nascida e criada em Manaus, cujo ponto de vista sobre o comércio e os empresários palestinos me ajudaram a formular hipóteses importantes.

Com as mulheres eu conseguia mais liberdade inclusive para gravar as conversas e, embora eu evitasse esse recurso, o fato de eu estar fazendo pesquisa nunca era esquecido. Foi a própria Ranya quem deixou isto claro. Na ocasião em que ela contava sobre as obrigações esperadas por homens e mulheres no Ramadã, eu não pude deixar de puxar meu caderninho de anotações para registrar algumas coisas. Eram muitos detalhes que envolviam nomes árabes dos quais eu poderia esquecer. Enquanto eu anotava ela exclamou surpresa: “Ah, então você tem um caderninho. Eu sempre ficava me perguntando, mas como a Bárbara consegue lembrar de tudo depois?"

Definitivamente o mito da participação desinteressada caiu por terra. Era óbvio que Ranya e os demais controlavam seus discursos, temendo os efeitos que elas pudessem evocar, já que seriam registradas. Não obstante, Ranya sempre procurava ser gentil e agradável, e foi através dela que conheci suas amigas Manal e Sônia, e sua cunhada, todas nascidas na palestina. Os seus respectivos esposos também não se sentiam a vontade para conversar comigo, principalmente o irmão de seu marido que não disfarçava a desconfiança sobre minhas intenções. Nos primeiros encontros eu não podia deixar de notar esta desconfiança, que eu não conseguia atribuir a nada além do fato de eu ser uma estranha com uma vontade pouco comum de querer conhecer suas vidas.

Demorei um pouco para entender o porquê dos tratamentos às vezes tão ásperos. Com a observação de outros indícios pude concluir que as relações comerciais revelam muitos temas delicados, próprios da atividade e da relação dos palestinos entre si e com o dinheiro. Esta percepção foi sendo construída na medida da extensão de minhas relações com algumas mulheres, idosos e crianças, indivíduos que estão à margem das decisões e contratos 
financeiros, seja porque não tem esse papel, ou porque já o perderam, ou também porque não assumem um comprometimento moral com a manutenção de uma ideia simétrica e harmônica das relações entre si. O Sr. Farid por exemplo, apesar de aposentado, ainda é ativo nesse tipo de relação e isso determina o modo como constrói sua versão da colônia.

Alguns dos interlocutores declaram que a colônia possui 300 famílias. Para outros, esse é um dado inflacionado, pois o número não passa de 200. Embora não haja dados censitários desse perfil familiar, esta dissertação está longe de representar os sujeitos abrangidos pela colônia. Dito isto, retenho que a colônia se refere ao conjunto de práticas e discursos acionados pelos meus interlocutores que considero como sendo "mecanismos elementares". Estes mecanismos estão combinados à análise que me permite dar sentido a suas dinâmicas de produção e reprodução. Isto implica dizer que o termo é fruto da minha análise, e não uma representação que se pretende real em termos empíricos. O que pretendo demonstrar aqui é que as relações entre estes sujeitos expressam elementos verbais e não verbais que tem por efeito a produção do senso de colônia.

As articulações teóricas que apresento tentam dar conta das situações de campo, a saber: observações, conversas, escutas e outras percepções acontecidas em um total de cinco meses residindo em Manaus. A produção de dados empíricos contou com um período de quinze dias de pré-campo no mês de novembro de 2013, e de um campo mais direcionado entre os meses de março e julho de 2014. A minha incursão nas vidas desses sujeitos se deu de uma maneira forçada, de certa forma, pois eu não possuía nenhum vínculo anterior ao da iniciativa desta pesquisa. Comecei tentando contatos por e-mail e telefone com o que eu conseguia encontrar pela internet, e também através de uma família muçulmana residente em Belém, cidade onde possuo moradia.

Isto definiu o meu percurso em campo, pois pela investigação das informações sobre palestinos em Manaus na internet eu consegui entrar em contato com o Sr. Omar. Já que ele se mostrava como um sujeito representante dos interesses coletivos e um exemplo de sucesso empresarial, posso dizer que eu comecei pela ideia abstrata de "colônia" para chegar embaixo nas relações de troca. Como coloquei mais acima, na época do contato com Omar eu estava bastante orientada e a par de algumas expressões públicas de palestinos no Brasil. À medida que fui conhecendo mais pessoas, outras exigências analíticas se fizeram necessárias, e isto se reflete no modo como estruturei o meu raciocínio e elaborei minha escrita. 


\section{A dissertação}

Esta dissertação possui três capítulos ou três passos metodológicos pelos quais construo e interpreto meu objeto. No primeiro eu apresento uma síntese dos estudos sobre palestinos e árabes no Brasil que modularam meu olhar acerca das dinâmicas públicas de organização destes sujeitos. Alguns trabalhos discutem dimensões prosaicas da vida dos palestinos no Brasil, como o dia-a-dia dos sujeitos pesquisados, os casamentos, as memórias, as relações de gênero, o trabalho, o ritmo urbano, etc. Deles extraí hipóteses, categorias e conceitos para pensar o meu caso, dos quais destaco as noções de "rede social" e "família bilocal"3.

Ainda no primeiro capítulo desenvolvo as implicações do ambiente de inserção destes imigrantes para conjecturar sobre suas práticas e sobre seus pensamentos acerca delas, também para marcar como a retrospectiva do passado pode ter efeitos de produção da colônia. Nesse plano também amplio a questão do porquê mascatear para sinalizar que isso reflete um tipo bilocal de organização da família, e que a origem também é uma variável importante para as primeiras ações como colônia. A discussão da noção de rede social ajuda a pensar as relações mobilizadas por estes imigrantes na decisão de partir para o Brasil e de como e onde trabalhar, e também de como se constitui e se mantém a organização da família.

Nesta análise, aponto que o fundamento da noção de rede social é bastante próximo do princípio da antropologia econômica, pois ambos reconhecem que os elementos afetivos, materiais e simbólicos que passam no fluxo das relações são prescritos pelas regras existentes. Neste sentido, admito que as relações e as trocas são complementares, pois auxiliam na compreensão de um importante mecanismo de relações duráveis que considero como sendo expressão de um regime de dádiva. Por isso sugiro que determinadas relações produzem um sentido de grupo que aqui é chamado de colônia, e podem ser entendidas dentro da perspectiva de ordem transacional, no sentido empregado por Parry \& Bloch (1989). Na sequência, demonstro como algumas atitudes e trocas entre palestinos e parentes respondem à uma ordem transacional nos termos das prescrições e normas moralmente aceitas para a manutenção da colônia.

No segundo capítulo desenvolvo as implicações da economia da dádiva, para dar sentido a outros dados sobre os contratos no espaço do mercado. Assumo que os empréstimos de dinheiro e transmissão de outros bens dão vida a estas relações entre as partes contratuais,

\footnotetext{
${ }^{3}$ Para dimensionar de modo mais adequado os dados elaborados nesta dissertação, utilizo o conceito de "família bilocal" como uma articulação entre o padrão de residência bilocal (em Manaus e na Palestina) de uma mesma organização doméstica (patrilateral), com as implicações da família extensa ou transnacional discutidas por Portugal (2007) e Feldman-Bianco (1995; 1999).
} 
e que o "dinheiro" é um mecanismo de transferência que tem a qualidade de revelar algumas implicações das relações entre as partes contratuais por serem sujeitos morais. Argumento que o "dinheiro" pode adquirir um valor pessoal a depender do tipo de relação em que é utilizado. Além do dinheiro, identifico outras situações em que a qualidade do doador é valorizada, ocasião que indica disputas para alcançar bens incomensuráveis e compartilhados como valor pela colônia.

Por fim, destino o terceiro capítulo para demonstrar como outros valores ou sinais de prestígio competem com as performances culturais públicas, e emergem a partir de pessoas que não contribuem com dinheiro para as ações da colônia, mas se esforçam por manter outros caracteres de valor, como a "família árabe". Nesta parte faço um forte uso da ideia de sentimento de honra para dizer que não só o pagamento de uma dívida financeira faz equivaler doador e donatário (ainda que ela não cesse de modo terminante, como se verá) num reequilíbrio da moral, mas outras circunstâncias emergem em que a necessidade de preservação da honra é declarada. Para isto, argumento que a produção e reprodução da "palestinidade" na família é fundamental, processo em que ficam evidentes as estratégias de subjetivação da mulher, considerada essencial para a reprodução do costume.

Os três passos descritos acima amparam o eixo central desta dissertação: a de que a colônia enquanto conjunto de moralidades, relações e trocas, se constitui fundamentalmente por processos de separação entre os espaços da casa e do mercado, e pelos processos de transformação que isto implica. Estas são as arenas privilegiadas da minha descrição sobre como se produzem sujeitos morais palestinos em Manaus. Estes espaços destacam uma oposição entre o regime de troca marcado pela conduta individualista das ações comerciais, e o regime da dádiva que permeia a relação entre palestinos e fornece o repertório de sustentação de uma ordem transacional de longo-termo. Estes espaços são complementares e dependentes por disponibilizarem os elementos materiais, afetivos e simbólicos da produção da colônia. 


\section{CAPÍTULO 1 - A FORMAÇÃO DE UMA “COLÔNIA PALESTINA" EM MANAUS: PERFORMANCES LABORAIS E CONDICIONANTES HISTÓRICOS}

Neste capítulo começo por apresentar os principais interesses de estudos produzidos sobre palestinos no Brasil, por cuja leitura iniciei meus esforços de enquadramento analítico para o caso dos indivíduos que se reconhecem enquanto palestinos em Manaus. Nesta ocasião, aproveito para destacar e reconstituir a conformação de temas recorrentes nestas pesquisas, que também se encontram em muitas produções sobre a imigração sírio-libanesa, no intuito de marcar as proximidades e os distanciamentos na construção de meu problema de análise. Eventos como os tipos de inserção na vida social e econômica nas cidades brasileiras e as práticas matrimoniais têm implicações no processo de formação da "colônia palestina de Manaus", que é como os sujeitos pesquisados se referem ao coletivo do qual fazem parte.

$\mathrm{Na}$ terceira e quarta seções deste capítulo, abordo eventos que marcaram a conformação da colônia palestina em Manaus. Deste processo, identifico o que designo como um período de adaptação e acomodação de suas atividades econômicas no setor comercial da cidade, entendendo-o como um resultado de um conjunto de contingências que acionam um background migrante em articulação com as transformações macroeconômicas da época. Esta articulação garantiu a colimada "progressão de vida" para alguns, que funcionou como estímulo para o deslocamento dos demais. O "sucesso" é contado em versões reveladoras de conteúdos relacionados a um lugar diferente da atuação comercial, pois remetem à organização familiar e aos preceitos morais, que sugerem uma expressão da convergência de perspectivas alheias ao do espaço onde as ações comerciais acontecem.

Argumento que impressões do passado ou a reorganização da memória relativa ao trabalho, atendem tanto a um projeto individual de elaboração de um self capitalista ou empresarial, como também funcionam como marcadores de prestígio e autoridade na colônia, principalmente quando resultam de condutas "limpas" ou que observam preceitos religiosos. Sendo assim, as vozes constitutivas deste capítulo são sobretudo de homens mais velhos, responsáveis por dar as primeiras condições de reprodução do coletivo no comércio, e de parte de seus continuadores. Mas as outras vozes, como a de mulheres e de outros homens "mal-sucedidos" nos negócios, foram muito importantes para a construção do lugar que ocupam os discursos dos sujeitos masculinos e bem-sucedidos. 
Por fim, empreendo uma discussão em torno da noção de rede social como uma tentativa de evidenciar aspectos das relações entre os interlocutores desta primeira seção, principalmente no que concerne à inserção deles na vida econômica e social de Manaus. Nesta parte defendo a ideia de que, no caso dos palestinos de Manaus, a atividade de mascate propalada como o principal trabalho entre imigrantes árabes no Brasil, acontece pelas implicações da rede que estes imigrantes mobilizaram para sobreviver neste ambiente urbano. Com esta abrangência sobre os mecanismos de inserção no comércio, antecipo que as demais táticas de reprodução enquanto "palestinos" requerem uma reprodução da família que se dá tanto em Manaus como na Palestina, cujas relações definem os diversos elementos transacionados por estes sujeitos.

\subsection{Panorama dos estudos sobre palestinos no Brasil: contextos e escolhas interpretativas}

Existem atualmente cinco trabalhos acadêmicos, entre teses e dissertações, defendidos em programas de pós-graduação em Antropologia no Brasil que tem como foco os palestinos no Brasil, a saber, a tese de doutorado de Denise Jardim (2000); a dissertação e tese de Sonia Hamid, defendidas em 2007 e 2012 respectivamente; a dissertação de Daniele Prates (2012); e a dissertação de Roberta Peters (2006). Outro trabalho que inclui interlocutores palestinos é o de Claudia Espínola (2005), uma tese de doutorado também defendida num programa de pós-graduação em Antropologia Social, mas que versa sobre um coletivo árabe muçulmano mais amplo.

Nesta seção também dialogo com outros trabalhos em antropologia e demais ciências sociais e em história que apresentam discussões acerca das atividades laborais e da construção da identidade social de imigrantes árabes no Brasil. São os trabalhos de Nunes (1996), Osman (2008), Ribeiro (2011), Lesser (2001), Castro (2007), Montenegro (2002) e Silva (2008). As discussões selecionadas abordam aspectos interessantes da adaptação de estrangeiros nas atividades urbanas, bem como das dinâmicas de socialidade entre pessoas com experiência no trânsito internacional, que acionam a origem "árabe" e/ou outros elementos para dar sentido à experiência de coletividade no Brasil, como a religião e a ancestralidade comum. Diante de tal background, procuro comparar ou testar as ações, discursos e projetos dos meus interlocutores com as hipóteses e situações descritas na literatura especializada. 
A tese de Denise Fagundes Jardim, intitulada "Palestinos no extremo sul do Brasil: Identidade étnica e os mecanismos e produção da etnicidade. Chuí/RS”, defendida em dezembro de 2000, é a primeira tese cujo escopo envolve um coletivo de palestinos do Brasil. A tese cruza a temática da organização deste agrupamento no Brasil com a da situação de fronteira entre Estados-Nações, e propõe retornar à questão da gênese dos grupos sociais pela investigação das situações ou condições que geram uma "adesão" à determinada "invenção" de uma "comunidade" ou "grupo", com foco nos contrastes significativos através dos quais o idioma étnico opera e o impacto para a localidade do Chuí e para os agentes envolvidos.

Seu estudo demonstra que a vinda desses árabes-estrangeiros é viabilizada pelos laços familiares que mantêm na cidade, fato imprescindível para sua permanência no país, dado que também se apresenta nos demais trabalhos sobre esta categoria de imigrante bem como nos que versam sobre a imigração árabe em geral, como se verá posteriormente.

A autora entende que há uma rotinização de sentimentos coletivos, ou seja, uma preocupação em repetir expressões de uma moral que forja pessoas a partir de elementos comunitários, e que a etnicidade aparece como crença subjetiva, cujos laços originários são atualizados. A partir de uma descrição minuciosa conseguida por alguns anos vividos em companhia regular com os sujeitos pesquisados, a autora mostra que a inserção dos filhos dos imigrantes nascidos no Brasil na "causa palestina" é resultado também de investimentos internacionais para a "autodenominação" como palestino, como os da OLP (Organização para a Libertação da Palestina), que se articulam com demandas familiares e locais. Nesse e em outros casos, fica evidente que discursos "nacionalistas" se impõem como explicação da formação dos coletivos.

Reconheço que o coletivo de palestinos de Manaus é também objeto de discursos nacionalistas na sua conformação enquanto grupo para finalidades específicas. Além disso, contudo, demonstro que existem outros fatores no nível das práticas que sugerem um princípio de coletividade. Esta diferença pode derivar do fato de que os sujeitos pesquisados por mim provêm de um mesmo vilarejo, de modo que há uma possível continuidade de relações precedentes à migração. No Chuí, ao contrário, Jardim (2000) encontrou trajetórias díspares, com itinerários entre diferentes cidades brasileiras e por motivos diferentes, de modo que tais palestinos não fazem parte de uma única rede de relações anterior, tendo como única coisa em comum os fatores que levaram a emigração: a procura de trabalho que não se encontra no lugar de origem. 
Jardim (2000) percebeu uma "rede" de relações e informações em que há o reconhecimento de posições diferentes entre estabelecidos e recém-chegados, e que definem as inserções e os vínculos conquistados entre os locais. Para isso, Jardim (2000) considera a distribuição dos lugares sociais nas relações de poder, ou empiricamente, os eixos de poder pelos quais seus informantes operam suas relações sociais: os tipos de lojas e sua localização entre áreas privilegiadas ou marginais. Os relatos colhidos também evidenciam que a escolha de Chuí era guiada pela expectativa de ajuda para a inserção no mercado local pelos patrícios. O próprio estado brasileiro manejou a distribuição dos refugiados palestinos com base nessa expectativa, como se verá no trabalho de Hamid (2012).

A tese de Jardim também indica outro dado recorrente entre outros coletivos de imigrantes palestinos, inclusive no de Manaus: um intenso trânsito internacional, idas e vindas de parentes e novos empregados que chegam nas grandes lojas e que procuram instalar pequenos comércios, gerando, portanto, diferenças de idade, inserção e posição. No caso dos interlocutores de Jardim (2000), migrar foi um projeto individual, mas existem casos em que essa necessidade individual "explicita" uma rede familiar comprometida com a migração, e neste caso a família aparece como parte da viabilidade da chegada e constitui parte de sua estratégia, mas quando a rede de parentes inexiste, outras são tecidas no Brasil com base numa ideia de "comunidade de origem". Segundo a autora, a lógica que os faz andar pelo Brasil é a dos contatos pessoais com os patrícios, parentes e informantes que indicam lugares promissores para o comércio.

Em seu trabalho, Jardim (2000) traz à tona um assunto bastante comum nestes estudos, o da atividade de mascate, que na sua pesquisa se caracteriza como uma opção de trabalho que se realiza no intuito de ter autonomia em oposição à "tornar-se colono ou empregado". A autora justifica a atividade mobilizando o pelo fato de que além de não dominarem o português, essa opção foi provocada também por não possuírem condição para trabalhar na lavoura por estarem sozinhos, sem a família que lhe garantiria a inserção neste ramo da economia, como previa a política para imigrantes de outras nacionalidades. A atividade de mascate é garantida através de uma ideia de retorno rápido e necessário à sobrevivência, uma vez que estes chegavam com pouquíssimos recursos materiais. A atividade foi favorecida porque o panorama econômico que se apresentava no Chuí era o de uma fronteira de expansão para mascates.

Tal tendência pode ser verificada em toda presença árabe no país, uma vez que a expansão desta migração sempre acompanhou os grandes ciclos econômicos no Brasil, que serviam como forma de viabilizar o seu comércio. Neste sentido, a escolha do trabalho de 
mascate não tem a ver com um cálculo direto da possibilidade de viabilizar um retorno financeiro para voltar à terra de origem. Na pesquisa de Jardim (2000), o retorno é um projeto pensado a longo prazo, e depende, portanto, do ato de outras pessoas além da capacidade de ampliar o capital. A primeira geração de "estabelecidos", de mascates árabes no Chuí, faz parte de uma trajetória de interiorização e busca de novos mercados, onde a valorização do sofrimento, do trajeto e das dificuldades encontrados durante o percurso são estratégias que acabam respaldando a posição pleiteada de "mais antigo".

A existência de palestinos como segmento majoritário ante a diversidade de origens e nacionalidades no Chuí foi produzida através de iniciativas coletivas que tornaram pública a “questão palestina", da qual se traçou uma "origem comum", atributo de uma "coletividade". As diferenças em relação aos outros árabes da região referem-se a critérios de antiguidade e poder que conseguiram obter frente aos locais. Jardim (2000) se deparou com uma forte organização comunitária que busca representatividade frente à sociedade abrangente. As iniciativas coletivas, naquele caso, propiciam inserções na vida pública e profissional, interesses alimentados em parte por organismos internacionais de representação da "causa palestina" e das famílias em inseri-los na localidade do Chuí e em redes de sociabilidade de origem árabe.

A preocupação com a "ordem global" é fundamental na dissertação de mestrado da Daniele Abilas Prates (2012), intitulada "O fio de ariadne: deslocamento, heterotopia e memória entre refugiados palestinos em Mogi das Cruzes, Brasil e Burj al- Barajneh, Líbano". A autora prioriza as interconexões desenvolvidas por alguns dos refugiados palestinos que desembarcaram no Brasil em 2007, a partir da análise da reelaboração de espaços sociais nas dimensões nacional e transnacional. Trata-se de entender não apenas as causas da migração e a recepção na sociedade de acolhida, mas as comunidades de pertencimento criadas e o que a autora chama de "habitabilidades" por elas providas.

A autora sublinha uma diferença entre o seu trabalho e o de Denise Jardim, que parece se localizar na ideia e importância que o conceito de "transnacionalidade" tem para cada um deles. Jardim tem reservas a respeito desse conceito enquanto que Prates o toma como fonte fundamental para o entendimento das formas de ser palestino. Mas suponho que a diferença também reside evidentemente na diferença dos próprios sujeitos pesquisados, pois enquanto Jardim se ocupou da análise de um coletivo já acomodado, Daniele Prates lidou com a situação de refugiado. Isso marca basicamente duas categorias bem diferentes em termos de direito, pois, como afirma a própria autora, a categoria "refugiado" se ancora num sistema de pensamento que não o inclui na sua dinâmica presente, mantendo-o suspenso em uma condição de provisoriedade. 
O contraste entre as duas análises explicita o potencial que a discussão contemporânea sobre refugiados palestinos tem para pôr nova luz sobre o estudo da condição desses imigrantes. Isto porque a aquisição de uma condição estável e legal no país não implica numa ruptura ou cisão definitiva com as relações mantidas no e com o país de origem. A acomodação pode dar um outro sentido à vida desses sujeitos que abandonam uma condição de provisoriedade; mas isso não os retira definitivamente de uma condição anterior ao processo migratório, de modo que podem ainda ter como referência um repertório distinto do que é reconhecido como sendo próprio ao seu lugar social no Brasil.

A ausência de lugar social a que se remete a autora significa o não reconhecimento enquanto participante economicamente ativo da comunidade em que se encontra, ao fato de não ocuparem o "mesmo lugar" dos brasileiros, visto que não são cidadãos e, neste sentido, refúgio é um não-lugar. O conceito de não-lugar empregado pela autora tenta dar conta da multiplicidade de espaços de pertencimento que são estabelecidas pelos diversos deslocamentos aos quais seus interlocutores foram submetidos. Para a autora, "há um afastamento de si", visto que o refugiado deve reconstruir sua identidade e suas redes de pertencimento. A meu ver, a proposta expõe a tensão entre os sentimentos de pertença construídos pelo idioma da ordem categorial de Estado-Nação e aqueles mobilizados pelos próprios sujeitos.

Os interlocutores de Prates (2012) se defrontam com a falta de um lugar apropriado onde poderiam dar curso aos seus empreendimentos para a autossuficiência em termos materiais, e sofrem violências física e simbólica decorrente do momento de transição de status vivenciada no Brasil. Neste ponto, a autora pensa com as categorias de Van Gennep e Turner, a saber: liminaridade e communitas respectivamente, e também com as categorias de estabelecidos e outsiders, construídas por Norbert Elias, como esforço teórico para referendar que a carga semântica do termo "refugiado" quer dizer ao mesmo tempo "trânsito" e "acomodação".

Para ela, o refugiado é persona liminar, não reconhecido pelos critérios usuais da sociedade brasileira, e daí a ambiguidade, pois se localiza na fronteira de não-mais-classificada ou ainda-não-classificada. Sendo assim, "para os palestinos, o sentido é produzido a partir da ausência do lugar, como também na relação com um grupo de pertencimento diaspórico: os palestinos, em âmbito geral. Para as instituições, ele é construído a partir da alteridade - são os de fora que precisam de proteção" (Prates, 2012, p. 47). É nesse ponto também que surge o "novo mundo do exilado" que menciona Edward Said, ou a communitas apontada por Turner; 
um lugar em que o indivíduo se percebe como vitimizado, marginalizado por Estados-nações ou como indésirables, em que pesa espaços de comunicação e de sociabilidade a partir de conexões locais e transnacionais nos termos de Ulf Hannerz 4 .

O conceito de "heterotopia" de Michel Foucault, de coexistência de muitos mundos fragmentados, expressa bem para a autora a justaposição de espaços incompatíveis vivenciados pelos refugiados à medida que reconstroem as suas vidas. Entendo que a sua preocupação em identificar nos refugiados a série de marcadores de diferenciação que acaba por não os incluir na sociedade brasileira parece essencializar a própria ideia de "sociedade brasileira", uma vez que a "inclusão" focada aqui não é nas relações, uma vez que ocorrem pelo simples contato com os nacionais, mas a da falta dos direitos gozados pelos cidadãos. Sendo assim, o que a autora considera como "condição de refugiado" é pertinente a muitos outros brasileiros que vivem situações semelhantes das que conceitualiza como "invisibilidade" e "não-classificação".

Para a autora, o sujeito refugiado está em construção de si enquanto sujeito de direitos e enquanto "palestino". A autora se apoia também na noção de "eventos críticos" de Veena Das, da qual elabora a ideia de que para os casos dos refugiados palestinos, os eventos críticos foram os momentos em que os referenciais convencionais foram suspensos, alterando as categorias dentro das quais as pessoas operam, dando origem a novas formas de ser e estar no mundo. Para resolver a tensão entre as disposições estruturantes na construção dos sujeitos com a agência e dinâmicas contra-produtivas ou reativas que possuem, Prates (2012) lança mão do conceito de habitus de Bourdieu que assegura um conjunto dinâmico de relações sobrepostas que garantem a mutualidade entre o mundo e o agente individual.

Em campo também pude perceber a necessidade de expressar a mutualidade vivida pelos meus interlocutores, uma vez que vivem o cotidiano comercial de uma maneira particular, o que não quer dizer que esta situação seja exclusiva aos migrantes. Neste sentido, invisto na ideia de que é possível pensar em diferentes modos de dar sentido à atividade comercial, e ao próprio dinheiro quando este faz parte do contrato entre pares ou entre parentes. Sugiro que, não obstante tratarem-se de sujeitos acomodados ao solo brasileiro, economicamente ativos e que se consideram responsáveis pelo desenvolvimento da cidade de Manaus, determinadas ações e expectativas respondem a um sentimento cujas "raízes" não se encontram ali, ou pelo menos, não são reconhecidas desse modo, embora o sentimento de "grupo" se dê pelas circunstâncias da migração.

\footnotetext{
${ }^{4}$ Deste autor, Prates retém a compreensão de que o estudo da contemporaneidade deve considerar uma condição transnacional, em que pessoas, culturas e lugares são constituídos por meio de interações, relacionamentos e redes.
} 
Voltando à dissertação de Daniele Abilas Prates (2012), as situações em que ocorrem confrontos entre a moralidade dos refugiados com as enfrentadas no contexto de Mogi das Cruzes são resolvidas pela interlocução com a proposta de Fredrik Barth (2005), que trata de processos sociais específicos de controle, silenciamento e apagamento das novas experiências vividas. Estes processos instauram a referência ao passado e posicionam os indivíduos em relação à sociedade na qual estão inseridos, abordagem bastante explorada na dissertação de Sonia Hamid (2007), intitulada "Entre a Guerra e o Gênero: Memória e Identidade de Mulheres Palestinas em Brasília”. Neste trabalho a autora articula ao estudo das memórias de mulheres palestinas os grupos aos quais pertencem, como família, classe social, e seus mais distintos grupos de convívio, por entender que a memória individual seria um "ponto de vista" sobre a memória coletiva.

Neste sentido, Hamid (2007) afirma que um aspecto invariável e imutável das memórias estudadas é relativo à Guerra dos Seis Dias de 1967 e aos eventos de 1948 pois, segundo a autora, "a necessidade de manter e reforçar a identidade "palestina" está relacionada ao profundo interesse do grupo de reconstituição e criação de um Estado Palestino, se conformando também como uma identidade política assumida" (Hamid, 2007, p. 23). Para ela, a lembrança é estimulada por eventos ou pessoas do presente, que orientam para diferentes memórias ou interpretações do passado, que é reconstruído, portanto, a partir do presente. A autora dedica especial atenção à memória de gênero, no intuito de demonstrar como determinadas memórias estão ligadas às posições que os sujeitos ocupam nas estruturas de gênero.

As entrevistadas tendem a estabelecer uma identidade e uma diferenciação fortemente marcadas pelo modo como se dão as relações de gênero, que também é um dos principais símbolos que revelam uma "tradição" ou "cultura". Outros eventos promovidos pelas instituições muçulmana e palestinas, e outras performances, também são considerados processos de rememoração coletiva. Tudo parte de um enquadramento da memória resultante de uma socialização histórica que serve para "manter a identidade individual e do grupo ligada à existência passada e futura de um território" (HAMID, 2007, p. 88). Sônia se defrontou com a autoafirmação como "refugiadas" por algumas de suas entrevistadas, que se diferenciavam pelos fatores que definiram uma saída compulsória do território, o que também conferia particularidades no tecer de suas memórias. Mas é na tese de doutorado que a autora elege o tema do refúgio como central no seu argumento. 
Em “(Des)Integrando Refugiados: Os Processos do Reassentamento de Palestinos no Brasil”, defendido em Junho de 2012, Sonia reconstrói de modo minucioso os processos que envolveram os reassentamento dos refugiados palestinos no Brasil. O feito se deu através de um programa promovido pelo governo brasileiro iniciado em 2007, para reassentar pouco mais de 100 palestinos que tinham estado durante 5 anos em um campo de refugiados no Iraque, e que haviam recebido a negativa de outros países que selecionaram apenas os refugiados de outras nacionalidades.

Apesar das diversas trajetórias dos indivíduos pesquisados, a situação de refúgio tem seu marco na $A l-N a k b a$, os eventos que envolveram a criação do Estado Israelense com as sucessivas guerras e desapropriações dos palestinos. Mas a heterogeneidade da categoria "refugiado", marcada pela pluralidade de experiências e trajetórias, encontra no paradigma nacionalista sua estruturação pelas agências internacionais. Tal categoria diz respeito às práticas de categorização e administração que tinha o intuito de torná-los governáveis instituindo novas subjetividades: "os discursos humanitários tendem a classificar os refugiados como espacialmente e culturalmente liminares, ou como "bare life", necessitando de intervenção humanitária. Intervenções estas que instituem novas rotinas, práticas, categorias, diferenciações, hierarquias e sentimentos na vida dos sujeitos" (HAMID, 2012, p. 60).

Ainda no campo dos refugiados discutidos por Hamid, os que aqui chegaram viveram processos como o da educação secular oferecida nos campos, que engendraram profundas transformações nos sujeitos, reconfigurando as dimensões de gênero, classe e geração. Esse e outros exemplos demonstram que o problema dos refugiados palestinos tem sido construído pelos países árabes através de políticas de manutenção deste status ou pela aplicação de restrições de direitos. A resolução do Estado brasileiro pelo reassentamento destes refugiados envolveu cálculos variados de fatores humanitários e políticos.

Em solo brasileiro, o tratamento aos refugiados assumiu uma postura ambígua, considerado ora como questão de controle via segurança pública, um expediente utilizado pela Cáritas Brasileira (a instituição brasileira responsável pelos "refugiados reassentados"), ora como caso de proteção pelo discurso dos direitos humanos, que foi o argumento utilizado pelo Estado brasileiro, com sua base no Ministério da Justiça, para conceder o refúgio. Muitos discursos colhidos dos funcionários da Cáritas e do Conare (Comitê Nacional para Refugiados) das instituições responsáveis pelo acolhimento se amparam na expectativa de que o refugiado deve sentir-se agradecido, retribuindo à dádiva-refúgio a eles concedida, assumindo-se como completa vítima. 
Para a autora, o processo tencionava despolitizar os refugiados, através da dispersão territorial com que planejava o reassentamento. Segundo a autora, isto se deve ao efeito da retórica assimilacionista, como demonstra a forma com que os funcionários da Cáritas entendiam a questão. Seus discursos exibem preconceitos e constroem uma ideia de "cultura palestina", acionada de modo totalizante, como autoexplicativa das ações dos sujeitos, o que elucida o lugar da "diferença cultural" na narrativa nacionalista brasileira. A tese demonstra que não obstante as agências identificarem os refugiados como "integráveis" (base discursiva para a produção de sujeitos integrados), o tratamento formal e informal dispensado às pessoas com este status nos primeiros dias de permanência no Brasil provou que na prática o que se dava era o contrário.

Sonia também expõe que a "comunidade Palestina brasileira" não se viu responsabilizada pela integração dos refugiados, uma vez que viam o programa de reassentamento como uma solução "técnica/humanitária" e/ou "individual”. A alegação da Delegação Especial da Palestina no Brasil (DEPB) por exemplo, defendia que os reassentados deveriam ficar no Oriente Médio, onde possuíam proximidade linguística, cultural e redes de parentesco. Mas a posição contava com algumas contestações, principalmente aquelas organizadas pelo MOPAT, Movimento Palestinos para Tod@s.

Na tese de Claudia Espínola (2005), a noção de transnacionalidade tem importância central para a compreensão da organização de sua unidade de análise. A autora se ocupa em identificar o processo de intenso fluxo entre global e local na comunidade árabe-muçulmana de Florianópolis constituída marjoritariamente por palestinos. Nesse caso, Espínola (2005) aponta que o ataque às Torres Gêmeas, conhecido como o "11 de setembro", teve efeitos determinantes para estas pessoas. Trata-se de um exemplo de como os eventos internacionais podem influenciar de modo decisivo no sentimento étnico, situações possíveis dentro de uma lógica mundial de compressão de espaço-tempo com a consolidação de redes de lugares e dos lugares de rede, intensificação e diversificação dos deslocamentos populacionais que redefinem espaços internacionais.

A migração estudada é localizada no que considera ser uma "migração contemporânea", única pela extensão, tipo e rede, pois além da tradicional migração de trabalho, somam-se ainda as migrações clandestina e as de reagrupamento familiar. Neste tipo de migração os fluxos migratórios ampliam-se e diversificam-se em novas redes por conta do mundo globalizado econômica e culturalmente. Os deslocamentos atuais, portanto, combinam traslados definitivos e temporários, de turismo e viagens breves de trabalho e estudo, de modo que as identidades devem ser pensadas como fragmentadas, sincréticas e híbridas. 
Na corrente de autores como Portes (1996) e Sassen (1988), Espínola (2005) orienta a sua análise a partir da identificação da criação de um campo social entre dois lugares, o global e o local, em que circulam os "transmigrantes". O que se observa em seu estudo e naqueles que tratam da imigração árabe no Brasil é que na procura por sucesso econômico e mobilidade social, a família e as redes étnicas formais se constituem em suporte estrutural. Além dessas relações, Claudia aponta para uma outra rede fundamental, aquela que liga o grupo migrante com o país de origem e de acolhida, e que propicia a construção da nação de uma maneira desterritorializada através de todas as práticas transnacionais possíveis atualmente.

A imigração árabe no Brasil se caracteriza por uma imigração espontânea; não foi agenciada e nem teve empresas envolvidas, tendo sido apoiada, contudo, numa base familiar importante. Neste sentido, a trajetória da comunidade estudada por Espínola (2005) passou por basicamente três momentos, sendo o último aquele em que três eventos propiciam a formação de um novo ethos na comunidade: o ataque às Torres Gêmeas em 11 de setembro, a exibição da novela $\mathrm{O}$ Clone e a nova mesquita com a figura de uma liderança formal, uma configuração que tem na religião o recurso por excelência para a demarcação de uma identidade.

Para Florianópolis, migraram palestinos e alguns muçulmanos libaneses na sua maioria do sexo masculino que deixaram seus respectivos países à procura de melhores condições de vida e com a determinação do retorno. No Brasil passaram a trabalhar no comércio, um nicho que atraiu muitos imigrantes árabes, que satisfazia o anseio de não serem assalariados e com a esperança de acumularem bens em menor tempo. Mas o momento presenciado por Espínola (2005) foi o de efervescência da comunidade, uma situação sem precedentes:

\footnotetext{
O momento da consagração do espaço da mesquita, em edifício no centro da cidade, da construção do cemitério islâmico, da criação do comitê catarinense de apoio à causa palestina, da primeira passeata organizada pela comunidade árabe em prol dos palestinos, do momento onde as mulheres passaram a usar o véu, adotando o símbolo do Islã em todos os espaços públicos. Enfim estas novidades e acontecimentos recentes, todos de certa forma ainda em processo de elaboração pela comunidade, não por acaso se tornaram o foco de interesse desta coletividade. Manifestou-se claramente nas entrevistas e em todo o trabalho de campo, a efervescência deste momento tão pleno de significados (Espínola, 2005, p. 95).
}

No início em Florianópolis, os árabes-muçulmanos preferiram não ressaltar a religião como o aspecto diferencial, pois como religião minoritária, o ambiente era pouco favorável. Tanto é que a primeira mesquita foi construída somente em 1992, mais de trinta anos após a chegada dos primeiros imigrantes muçulmanos na cidade. Com a criação da mesquita, o espaço de interação entre árabes muçulmanos e os convertidos não-árabes se torna comum e finalmente com a inauguração da nova mesquita (que mudou de endereço) em 2002, o espaço 
público para o desenvolvimento de atividades religiosas, sociais, políticas e culturais é ampliado, efetivando a existência deste grupo como a comunidade árabe-muçulmana de Florianópolis (ESPÍNOLA, 2005, p. 89).

A construção da mesquita de Manaus também é uma marca crucial na elaboração das relações entre os colonos. O espaço religioso nessa cidade foi inaugurado em 2013, e passou a ser o lugar oficial para o encontro dos palestinos, quando ocorrem deliberações e são tomadas as decisões de interesse comunitário, que agora precisam respeitar as exigências de respeitabilidade e cordialidade que o lugar impõe. Além de promover uma reelaboração do caráter das relações, a mesquita ajuda a reelaborar também o próprio sentido de "colônia", conformando novas condições para o reconhecimento mútuo em que as interdições religiosas, apesar de provocarem tensões, funcionam como os princípios que controlam as fronteiras.

Como verifica Castro (2007) em um caso brasileiro, uma definição de como os muçulmanos e muçulmanas devem pensar e agir se estabelece nos interstícios entre a prática do Islã e a modernidade. O reconhecimento de si como "muçulmano" em situações onde se encontra como minoria, define o lugar de um modo de vida particular, que limita participações e compartilhamentos. Nestes espaços de contato, as identidades se tornam públicas e, pela ausência de fronteiras, são intensamente sentidas, de modo que as distinções religiosas são mais imediatas, mais próximas fisicamente e, portanto, mais assumidas, usando os termos de Goffman (1988) ${ }^{5}$.

Segundo Montenegro (2002), no Paraná, devido à história recente de imigração, a comunidade é organizada em torno de uma identidade árabe, de modo que a associação religiosa toma as características de uma associação étnica. O mesmo processo é verificado, ainda que com algumas variantes, em São Paulo, onde, não obstante a diversificação devido ao número expressivo de fiéis e de associações de todos os níveis, a identidade religiosa também não se separa de uma identidade árabe. Estes são exemplos de um movimento que vai contra os projetos assimilacionistas do Estado, no passado e no presente.

Outro elemento de coesão e que promove um sentimento de unidade é a adesão à "causa palestina", que resume os interesses dos movimentos organizados contra as ações do Estado de Israel e está estreitamente ligada ao processo de formação da identidade palestina.

\footnotetext{
5 Os modos como as comunidades com designação muçulmana se desenvolvem no Brasil evidencia escolhas em uma permanente reorganização das "coisas" da religião. A tese de Ferreira (2007) coteja as redes construídas pela Sociedade Islâmica de São Bernardo do Campo. Com este grupo de denominação islâmica, a autora percebeu que as divisões são constitutivas da estrutura da religião muçulmana. Ainda que o escopo do trabalho tenha sido a análise da performance como um modo de construção de elos, ou melhor, da elaboração de elos a partir do próprio conteúdo da religião islâmica, as relações entre muçulmanos árabes e brasileiros e entre os demais são, para a autora, bem traduzidas nos termos de fluxos, fronteiras e hibridismos elaborados por Hannerz (1997).
} 
Segundo Montenegro (2002), isto se deve fundamentalmente às lutas históricas por negociações de direitos civis e de territórios pela população palestina. Todos aqueles conflitos plasmam a identidade palestina, de modo que seus reflexos são observados também entre refugiados palestinos no Brasil, como nos casos estudados por Jardim (2003) e Hamid (2007). Seus dados também corroboram a tendência de que cada geração de imigrantes possui um comportamento diferente com relação à etnicidade no país de acolhida, que oscila entre a manutenção das tradições e costumes com a revalorização do étnico, e o projeto de adesão ao repertório de valores diferentes da sociedade de acolhida.

Sendo assim, os laços migratórios transnacionais se configurariam como outra fonte de diferenciação das comunidades. Espínola (2005) afirma que, entre os sujeitos pesquisados em Florianópolis, as viagens desempenham quatro funções essenciais: constituem um processo educativo dentro da tradição religiosa islâmica e da tradição árabe; tem papel importante em razão do casamento, das escolhas matrimoniais; a formulação de projetos de vida que definem a duração da estadia no Brasil e na Palestina; e como propiciadora do ritual de peregrinação, dentro do contexto religioso como obrigação muçulmana. São muitas as idas e vindas, e as redes familiares estão de tal modo conectadas que o trânsito é constante.

Segundo a autora, a manutenção de tradições se expressa sobretudo na ideia que se faz de "família", com delimitação de papéis e tipos de relações, respeito, normas, condutas, etc. No sistema de nomeação, na escola corânica e no Ramadã são mantidos e atualizados o sentimento de comunidade, bem como os retiros espirituais, os chamados "acampamentos", que envolvem crianças, jovens e adultos; a reunião semanal das mulheres na Mesquita etc. Sendo assim, estes indivíduos encontram-se ao mesmo tempo distantes e próximos de suas redes de parentesco, cujas regras são reforçadas na diáspora e bastante presente na vida do grupo. A estrutura de parentesco na qual homem e mulher têm papéis bem definidos é mantida: espera-se que o homem atue como provedor na realização de trabalhos remunerados, e a mulher na realização de trabalhos domésticos e como educadora dos filhos.

Tais fatos marcam presença também na dissertação de Roberta Peters, defendida em março de 2006, sob a orientação de Denise Jardim. O trabalho, intitulado "Imigrantes palestinos, famílias árabes: um estudo antropológico sobre a recriação das tradições através das festas e rituais de casamento", transita pelo registro desses eventos nas cidades de Porto Alegre e Canoas no Rio Grande do Sul. A declaração de que o casamento entre palestinos possibilita a continuidade de uma "raça" ou "povo" palestino em diáspora e que permite a transmissão de qualidades e atributos morais também é registrada por Hamid (2007). 
A família "espalhada", característica da configuração que Peters (2006) verifica em campo, tem como um facilitador moderno de encontros a internet, que propicia uma comunicação criando uma rede de contatos. No seu contexto de análise, a autora identifica um sistema de valores com três níveis distintos do que considera como honra: o primeiro diz respeito a um "nós" enquanto árabes e palestinos; o segundo reside no âmbito das famílias enquanto universo social autônomo; e o terceiro um sentimento de honra expresso nas relações de gênero ligadas a um repertório cultural que naturaliza os papéis. Assim, cada código responde a um contexto específico, e especialmente no segundo caso, os conflitos na parentela explicitam divisões sociais, que tem a ver com o seu modelo de organização e consequentemente com a normatização do mercado matrimonial.

O seu trabalho tem um recorte específico delineado pelos seus informantes, que teciam esta rede de relações pelo casamento entre famílias reconhecidamente grandiosas e tradicionais. O casamento é tido pelos informantes como o mais importante evento que reúne as famílias. Frequentemente ele ocorre entre primos paralelos, uma vez que são tidos como modelares. Estes eventos acionam distinções como quem são os palestinos que migraram ao Rio Grande do Sul, qual é a família que promove as festas, e quais os papéis performatizados durante o ritual. Há também a celebração de uma origem comum pela evocação da terra de origem nos discursos proferidos.

Sendo assim, pode-se concluir que os estudos antropológicos sobre palestinos no Brasil manifestam observações acerca do processo de inserção no Brasil em diálogo com dimensões transnacionais de existência, delineando sobretudo ações grupais ou como sendo características de um coletivo, em que trajetórias e processos de identificação são construídos como expressando um tipo coletivo de organização da experiência. No âmbito das ações de "palestinos" ou "palestinas", temos a produção de uma "memória" num processo mais amplo de produção de subjetividades individuais e coletivas na diáspora. Penso, portanto, em que medida alguns estudos sofreriam pela projeção de preocupações que supervalorizam as diferenças a despeito de outras preocupações que podem orientar a vida destes sujeitos.

Em ocasiões mais atentas às particularidades de situações ou indivíduos, como nos apontamentos sobre o mercado matrimonial, têm-se identificados, por exemplo, noções de honra, conflitos na parentela e outras divisões internas ao coletivo estudado, situações complexificadas pela consideração dos fluxos migratórios em novas redes por conta do mundo globalizado. Na tese de Cláudia Espínola (2005) por exemplo, as redes assumem 
importância fundamental, tanto para abordar a constituição do grupo em seus empreendimentos como para dar conta de práticas relacionadas ao lugar de origem. O título sugestivo de Peters (2006), "Imigrantes palestinos, famílias árabes: um estudo antropológico sobre a recriação das tradições através das festas e rituais de casamento", aponta para a negociação evidente dos processos de identificação de palestinos em solo brasileiro, que atendem por sinais relativos ao "árabe", um dado que também observo na minha experiência de pesquisa. Vale à pena, portanto, entender o lugar dessa classificação que tem tido considerações no campo dos estudos sobre imigração no Brasil.

\subsection{Ensaio sobre a imigração árabe no Brasil: o lugar da identidade e do trabalho}

Segundo Nunes (1996), no Brasil, os primeiros trabalhos sobre imigração surgiram entre as os anos de 1850 e 1930 fundamentados em duas preocupações básicas: a da imigração como meio de suprimento da mão-de-obra no processo de substituição do trabalho escravo pelo assalariado e, segundo, como ação voltada para as áreas desabitadas do sul do país. Uma vez que a imigração árabe não se inseriu em nenhum destes contextos, ela não despertou interesses. Nos termos de Nunes (1996), os primeiros trabalhos com foco em imigrantes libaneses no Brasil, entre 1950 e 1984, estavam preocupados em entender a integração cultural, econômica e política destes imigrantes, e de avaliar a mobilidade social ocorrida.

Os trabalhos de Oswaldo Truzzi, por exemplo, se enquadram à proposta do IDESP-São Paulo, que privilegiava pesquisas com etnias pouco estudadas. Numa abordagem inovadora, o autor explorou a imigração no contexto urbano-industrial. O seu intuito é o de analisar os principais determinantes das trajetórias percorridas pelos imigrantes árabes de São Paulo desde a última década do século XIX até os anos 1960. Até aqui as causas da imigração sírio-libanesa estão vinculadas à precária situação econômica da terra de origem e pela inferioridade dos cristãos em sociedades predominantemente islâmicas sob o domínio otomano.

As ações históricas em busca da etnicidade árabe no Brasil exemplificam a dinâmica da construção identitária na qual este grupo era visto como exótico e diferente. Como afirma Espínola (2005), a categoria “árabe” foi construída na emigração, podendo também ser considerada como constructo no exílio, já que se encontra presente nas demais partes da América. Lesser (2001) analisa a imigração sírio-libanesa no Brasil a partir do século XIX, cuja presença colocou em xeque os estereótipos a esse respeito, gerando ampla discussão 
sobre a possibilidade de se tornarem brasileiros. Tais debates foram acrescidos ainda pela luta desses imigrantes e de seus descendentes em uma negociação ampla de como a etnicidade “árabe” poderia transformar a identidade cultural, econômica e social do Brasil.

Estes imigrantes usavam estas contradições para criar uma "etnicidade hifenizada", na qual era implícita a ideia de brasilidade. As imagens dos árabes circulavam comumente, e foi identificada com a cultura ibérica, de tradicional influência no país. Essa relação foi endossada pela elite árabe-brasileira, no intuito de definir sua singularidade étnica dentro da identidade nacional brasileira. Não era difícil perceber essa tentativa de assimilação, mesmo porque os próprios meios de comunicação se encarregavam disso, bem como intelectuais como Gilberto Freyre e Câmara Cascudo, defendendo que os árabes eram ao mesmo tempo europeus, asiáticos e nativos do Brasil. As imagens tradicionais dos mouros também foram equiparadas com as ideias sobre judeus árabes que desembarcaram numa expedição indesejada no Brasil.

Neste sentido, o termo "sírio-libanês" oculta uma hierarquização real de privilégio, estando o turco em desprestígio numa escala em que o libanês é o mais prestigiado. Posteriormente isto se refletiu na imagem dos "mascates", momento em que se verificou o "uso da etnicidade para construir vínculos comerciais atacadistas e varejistas" (LESSER, 2001, p. 99). No Brasil a primeira atividade exercida pelos imigrantes árabes foi a de ambulante e, autores como Nunes (1996) afirmam que nenhuma outra categoria de imigrante identificou-se tão intensamente com essa atividade. Este comércio apresentava características próximas a um modelo encontrado em territórios árabes, representado "pela venda e a troca de produtos do trabalho, de vilarejo em vilarejo, de porta em porta, realizado pelos artesãos, comerciantes e pequenos fazendeiros" (NUNES, 1996, p.162). No Brasil, tal ocupação rendia bons lucros, requeria pouco capital e pouco conhecimento da língua.

O trabalho como mascate formou uma prática em contínua expansão. Nunes (1996) afirma que os altos lucros se deviam à dedicação ao trabalho, à inventividade e à cobrança do máximo preço que o mercado podia suportar. Dado que sírios e libaneses constituíram o primeiro grupo emigrado volumoso de destinação especificamente urbana na sociedade brasileira, é compreensível a sua constituição como o grupo pioneiro na atividade de mascateação, seguida pela criação de grandes estabelecimentos comerciais e da indústria. À medida que os imigrantes iam se estabelecendo, operavam no atacado e forneciam produtos aos recém-chegados, e pouco a pouco a rede constituída por indústrias, atacadistas, varejistas e comerciantes ambulantes foi se integrando entre pessoas de mesma origem. 
As características infra-estruturais brasileiras também favoreceram a mascateação, uma vez que a deficiente rede ferroviária tornava carentes de produtos as populações do interior do Brasil. Estes imigrantes chegavam ao Brasil no período de transformação da República descentralizada e rural para a nação industrial e consolidada. Samira Osman (2009) traz uma importante contribuição a este respeito.

Osman (2009) sugere que as condições mínimas para vir ao Brasil eram as de declarar a maioridade e um ofício, o que os vinculava ao exercício de atividades econômicas urbanas. A opção da mascateação se dava, na verdade, pelo mito que circulava entre os árabes de que se tratava de uma forma de enriquecimento rápido. Sobre este aspecto, a autora defende que a trajetória comumente verificada de mascates aos proprietários comerciais e industriais fora possível apenas àqueles que já chegavam com um capital prévio para se estabelecer e obter sucesso nessas atividades, de modo que a maioria atingiu apenas a propriedade de um estabelecimento comercial.

Neste ponto, os dados que apresento nesta dissertação se distanciam dos divulgados por Osman (2009). Nas narrativas sobre suas trajetórias em Manaus, os palestinos reiteram o fato de terem chegado com pouquíssimo dinheiro, e atribuem o sucesso ao trabalho árduo e à frugalidade, revelando redes de solidariedades e exclusividade no ramo. Sendo assim, tendo a me aproximar da hipótese de Nunes (1996), pois as relações travadas entre pessoas da mesma origem foram decisivas nestes processos. Além das estratégias associativas, sustento que só foram possíveis pelas oportunidades vislumbradas numa situação econômica específica: a situação da frente de expansão do comércio.

Além deste enfoque, trabalhos como o de Márcia Cabreira (s/d) constroem uma análise a partir do conceito de paisagem atrelado à memória e ao lugar, como o lugar de referência identitária, em que o trabalho aparece como meio de obtenção da realidade e reconstrução da identidade no novo lugar. O estudo de Paula Ribeiro (2011) sobre o centro comercial do Saara no Rio de Janeiro também é construído com base na perspectiva da História Social, ancorada principalmente no conceito de memória, como um fenômeno social que expressa o ponto de vista de um ou mais grupos e de uma ou mais correntes do pensamento coletivo.

Para esta perspectiva convém tratar os grupos pesquisados como definidos por "identidades culturais" específicas uma vez que são possuidores de "tradições culturais". A memória coletiva do Saara é, portanto, a composição das múltiplas memórias dos diferentes grupos étnicos presentes naquele espaço que diferenciam-se ao mesmo tempo em que se tornam únicos. É a partir desta configuração que, segundo a autora, se delineiam as relações sociais. 
Os resultados apresentados por Regina Silva (2008) corroboram com as teses de que no comércio estão concentradas as atividades da maioria dos imigrantes árabes. Em Foz do Iguaçu, o comércio é aquecido por conta do contrabando; estas oportunidades abertas facilitam a entrada de grupo estrangeiros. Ancorada em Simmel (apud SILVA, 2008) a autora afirma que são essas as condições que constituem como esfera privilegiada de interação do estrangeiro em qualquer comunidade.

O suposto sucesso econômico destes imigrantes também concorre para o estímulo à emigração em seus países de origem, para onde outros fatores aparentemente colaborariam para uma unificação, como a língua falada, as profissões e a religião. Contudo, segundo a autora, se estes marcadores simplificam uma autorrepresentação, eles também escondem clivagens internas. Tal clivagem se expressa no grande número de instituições e associações que fundam diferenças do ponto de vista religioso ou do país de origem. Em contrapartida, outros eventos públicos reforçam a ideia de uma "comunidade árabe" e reordenam as diferenças para além de suas clivagens internas.

Como se vê, grande parte da produção acadêmica sobre imigrantes árabes têm reforçado um perfil destes sujeitos como sendo exclusivamente urbano, com trajetórias que circulam basicamente entre o comércio e a indústria. As preocupações são basicamente as de compreender dinâmicas de trabalho, estratégias e organizações comerciais, configurações urbanas, criação e recriação de identidades árabes e libanesas, manutenção de fronteiras étnicas e memória. Poucos trabalhos, porém, problematizam outras dimensões que compõem este universo, como a questão de gênero (JARDIM; HAMID, 2007), ou da religião (EL KADI, 2012; MONTENEGRO, 2002).

No entanto, vale a pena considerar os sentidos que a palavra "urbano" pode provocar. Conceber a imigração palestina como sendo "urbana" pode não justificar a especificidade deste coletivo, uma vez que, como apontam os dados de minha pesquisa, estas famílias provêm de um ambiente eminentemente rural, em que a "experiência urbana" parece se referir ao contexto de inserção no Brasil. Não se trata, portanto, de uma "imigração urbana", mas de imigrantes de origem rural que têm como destino áreas urbanas para dar consecução a empreendimentos individuais e familiares gestados dentro de uma lógica própria do lugar origem, uma lógica que, quem sabe, sofre com a distinção entre rural/urbano. 
Diante disto, retenho a necessidade de considerar as dinâmicas do comércio varejista, o espaço por excelência de produção das condições materiais de existência dos palestinos da cidade de Manaus, e que por isso tem o potencial de descortinar implicações importantes para a compreensão dos modos de existir destes indivíduos. Sendo assim, considero também que o coletivo aqui representado mantém, além de uma afinidade "étnica" ou "nacional", outras afinidades que antecedem a migração e que acompanham suas experiências até os dias de hoje. Assumo que as implicações "étnicas" do termo "palestino", enquanto identificação que evoca uma dimensão transnacional, não são suficientes para entender a complexidade de suas relações e dos mecanismos de reprodução social.

Como expus acima, existem muitas evidências de que para os emigrados árabes já acomodados no Brasil a existência se identifica com o espaço do empreendimento comercial e que, portanto, advém de algumas circunstâncias propiciadoras, como os grandes ciclos econômicos que, para Denise Jardim (2003), se caracterizaram como fronteiras de expansão de mascates. É através desta discussão que inicio a minha construção analítica do modo de reprodução social deste coletivo. Para tanto, as minhas preocupações em campo foram a de investigar práticas rotineiras, e não a dos rituais ou grandes eventos, porque percebi indícios de que o senso de "palestinidade" também se encontra nas dinâmicas corriqueiras do comércio e no modo de produção de parentes ou da reprodução da família.

\subsection{0 ciclo econômico em Manaus na época dos mascates palestinos}

Antes de iniciar a apresentação dos interlocutores desta seção, suponho ser necessária a apresentação do contexto que recebia estes imigrantes, para tornar mais claro o modo como suas trajetórias são também conformadas pelas circunstâncias encontradas em Manaus. Neste sentido, entendo que a construção de uma parte da história econômica contada a partir de eventos críticos associados àquela situação, pode ajudar a situar as práticas dos sujeitos. Creio que este movimento foi uma demanda do próprio campo, pois os interlocutores trazem em suas narrativas algumas das principais transformações macroeconômicas da época, ainda que evocando relações de causalidade particulares.

Parecia que o primeiro imigrante de Beni Naim, e responsável pela migração dos demais, estava prevendo a oportunidade que lhes possibilitaria o trabalho que rendeu tanto lucro em Manaus: a abertura da Zona Franca. Este acontecimento determinaria seus rumos e 
os de suas famílias de uma forma inesperada até para eles, pois o quadro que antecede o ano de implantação da Zona Franca de Manaus (ZFM), em 1967, era de estagnação e miséria (SOUZA, 1978). A situação apenas ganhou algum movimento a partir da década de 1960, com a reorganização da economia extrativista para atender a demanda nacional de fibras de juta e madeira de lei.

Depois do colapso da borracha na década de 1930, o anacrônico extrativismo amazônico não pôde mais concorrer com os capitalistas da Malásia, cujo látex alcançara preços mais baixos devido aos menores custos operacionais (SOUZA, 1978). Mesmo antes da crise extrativista, Manaus já não tinha muita ligação com o resto do país, pois nela sempre perduraram os interesses econômicos dos mercados estrangeiros. Segundo Marcelo Carvalho (2009), até então vivia-se uma "decadência da vida interiorana, pela deterioração dos preços nas relações de troca, descontinuidade dos negócios, êxodo de empresários, políticos e profissionais, e pela descoronelização" (CARVALHO, 2009, p. 86).

A ZFM seria o plano ideal para promover a "integração nacional" e o "desenvolvimento regional" de um território estagnado economicamente depois do colapso da economia da borracha. As pressões para que o governo federal tomasse esta medida aumentaram ainda na década de 1930, quando os estados do sudeste viviam um rápido desenvolvimento industrial que tornou ainda mais pungente a necessidade de equalizar as disparidades que só aumentavam, no sentido de integrar as forças produtivas locais ao sistema econômico nacional.

Em 28 de fevereiro de 1967 sai o decreto federal 288 que cria a ZFM. O projeto se realiza no bojo das ações previstas pela Operação Amazônia, que incluiu também a criação do Banco da Amazônia (BASA) e da Superintendência do Desenvolvimento da Amazônia (SUDAM), no intuito de oferecer estímulos fiscais e de infraestrutura para investimento nas atividades comerciais agropecuárias e industriais. Mas a ZFM gerou mudanças com proporções muito além dos efeitos diretos de suas medidas, pois produziu externalidades que permitiram a dinamização de setores econômicos indiretamente afetados pelas vantagens do plano.

As principais ações da ZFM foram os incentivos fiscais pela isenção do Imposto sobre Produtos Industrializados (IPI) e do Imposto sobre Importação (II). Além disso, o governo estadual passou a conceder crédito e substituição do Imposto sobre Circulação de Mercadorias e Serviços (ICMS) e o governo municipal isentou as empresas do recolhimento de uma série de tributos. Houve também investimentos públicos e infraestrutura para a 
redução dos custos de transportes, além da disponibilidade de uma força de trabalho abundante e barata.

Para Carvalho (2009), ainda que os interesses tenham convergido para os das corporações transnacionais, a ZFM constituiu uma área de expansão da acumulação capitalista como um todo, pois permitiu a articulação de diferentes interesses: local, nacional e internacional. $\mathrm{O}$ setor industrial foi sendo claramente o mais privilegiado nessas transformações, e as medidas variavam ao sabor da ordem econômica internacional. Houve basicamente três fases distintas na política da ZFM, que afetaram fortemente o setor comercial, de muito interesse para as dinâmicas percebidas pelos palestinos que participaram de seu arranjo.

Entre 1967 e 1975, Manaus se tornou uma plataforma de importação de bens, que em outras regiões do país estavam proibidos devido às políticas de proteção da indústria nacional. Foi neste período em que o setor comercial mais se desenvolveu. Neste período, muitos empreendimentos eram presididos por pessoas de origem estrangeira, como sírios, libaneses, e um número bem expressivo de portugueses e judeus. Apesar do parco registro da imigração no Amazonas, têm-se boa documentação produzida por Samuel Benchimol principalmente sobre a imigração judaica, da qual também faz parte. Esta imigração é mais antiga e numerosa, e seus descendentes têm ocupado tradicionalmente posições econômicas importantes na sociedade amazonense.

Vale citar também uma publicação recente sobre os judeus em Manaus de autoria de Wagner Lins (2010). O autor faz circular que o ambiente amazônico também é o cenário no qual judeus marroquinos constroem sua identidade étnica. Segundo Wagner Lins (2010), a identidade contemporânea deste grupo na região se constitui pelo esforço em manter as características do judaísmo marroquino/sefaradita, por meio de "símbolos-multivocais", usando a terminologia de Turner. Estes traços os distinguem não somente da sociedade circundante, como também de outras comunidades judaicas do Brasil. Embora tenha havido algumas dissensões, os judeus marroquinos se integraram sem dificuldades à elite local, principal fator que os distinguem dos judeus marroquinos em Israel, onde possuem um estigma negativo.

Nos dados organizados no livro "Manáos do Amazonas: Memória Empresarial", publicado em 1994, quando assumia a diretoria da Associação Comercial do Amazonas (ACA), e também atuava como professor da Universidade do Amazonas, Benchimol dá uma prova da presença das famílias judaicas: 


\begin{tabular}{|l|l|}
\hline \multicolumn{2}{|c|}{$\begin{array}{c}\text { Tabela 1: Algumas empresas e pessoas que integram o quadro da } \\
\text { Associano Comercial do Amazonas em 1971 }\end{array}$} \\
\hline Abdon \& Cia & Jacob Paulo Levy Benoliel \\
\hline Abrahim Irmão \& Cia & Jacob Sabbá \\
\hline Abrahim J. Pazuelo & Jorge Assad Aucar \\
\hline Alberto Mimom Gonçalves Sabbá & Moyses B. Israel \\
\hline Ag. Zail Rep. E Corret. Ltda & Moisés Gonçalvez Sabbá \\
\hline Alfredo Jacob Gastuse & Paulo Levy \& Cia \\
\hline Benarrós \& Irmão & Sadala \& Cia \\
\hline Benchimol, Irmão \& Cia & Souza Arnaud \& Cia \\
\hline Benjamim Jacob Benzecry & Simões \& Cia Ltda \\
\hline Caram Abrahim \& Cia & Isaac B. Sabbá \\
\hline Elias Ramiro Bentes & Isaac Jacob Benzecry \\
\hline Ezagui \& Cia Ltda & Jacob M. Ezagui \\
\hline Felipe Isper Abrahim & \\
\hline
\end{tabular}

Fonte: Tabela elaborada pela autora com base nos dados de Benchimol (1994).

Sobrenomes como Benchimol, Sabbá, Benzecry e Benoliel são bem conhecidos no ramo comercial local até os dias de hoje, e abundam exemplos de inserção destes indivíduos quando os palestinos estavam ainda iniciando seus empreendimentos, de modo que o relacionamento com empresários de outras origens era inevitável. Os judeus eram importadores, atacadistas, industriais, joalheiros, donos de armazéns etc. Já a presença árabe se fez sentir na ocasião da imigração sírio-libanesa ${ }^{6}$, tendo sido atraídos pela economia da borracha, quando estes estrangeiros ocuparam setores do comércio e da indústria ligados à economia extrativista (BENCHIMOL, 1999). Apesar de o fluxo imigratório para a região não ter cessado, a vinda dos palestinos destoa deste padrão e faz parte de um novo contexto.

Em 1975, com o aumento do preço do petróleo e da taxa de juros norte-americana, a balança de pagamento brasileira entrou em crise, o que resultou no controle das importações através de uma política de cotas, que também atendia ao propósito de fomentar a nacionalização dos produtos das indústrias da ZFM. Assim, os produtos importados se

\footnotetext{
${ }^{6}$ Poucos são os estudos sobre a imigração internacional na Amazônia, e menos ainda aqueles que têm co mo pressuposto teórico a antropologia. Apenas estudos pontuais revelaram alguns aspectos da presença árabe na região, e trabalhos produzidos recentemente por alunos de iniciação científica no NAEA (Núcleo de Altos Estudos da Amazônia, localizado na UFPA), além da célebre obra dos manauaras Milton Hatoun e Elizabeth Azize, descendentes de libaneses, também fazem circular enredos sobre memória e identidade árabes aclimatadas no ambiente amazônico.
} 
tornavam escassos, o que não provocou desestabilização do setor comercial já que o restante do país ainda possuía tributação alta das mercadorias importadas. A situação só ficou desfavorável para o setor comercial a partir de 1991, com a política de liberalização econômica do governo federal que diminuiu a vantagem comparativa dos produtos de Manaus, porque diminuiu as taxas de importação em todo o território nacional.

Os palestinos que tiveram condições de abrir a própria loja antes desse período, mesmo com venda de confecções nacionais, adquiriram conhecimento das redes de relacionamento com fornecedores, e conseguiram situação confortável para estabelecerem-se e reproduzirem-se no varejo de confecções. Ainda que as ações da Superintendência da Zona Franca de Manaus (SUFRAMA) visassem investimentos de caráter predominantemente industrial, seus efeitos ainda beneficiam de forma indireta o setor comercial. Isto porque houve um aumento exponencial da população da capital, que do ano de 1970 para 2005, apresentou um crescimento de 1.333,980 habitantes. Isso se justifica também pela relativa estagnação econômica no interior do Amazonas e de regiões como o nordeste, de onde provém muitos imigrantes (CARVALHO, 2009).

Há de se notar a evidente exclusão da população local destes processos, mesmo dos que eram empresários. Autores como Marcelo Carvalho (2009) defendem que isto se deve ao fato de que ainda possuíam uma "cultura econômica extrativista". Em sua tese, este autor discorre sobre o modo como estes empresários tiveram que ajustar as suas práticas às mudanças decorrentes da Zona Franca, que oferecia um novo horizonte de ação e exigia um know-how em relações comerciais internacionais. Neste sentido, a situação pode ter beneficiado profissionais como os mascates, que não possuíam um negócio fixo ou um estabelecimento comercial, porque nestes casos a adaptação é menos complexa.

Os primeiros palestinos em Manaus já estavam acostumados a lidar com a circulação de diferentes mercadorias, que mudavam de acordo com a oferta e demandas muito instáveis, pois dependiam, dentre outras coisas, daquilo que conseguiam ter acesso. A atividade de mascate exige a mediação direta entre fornecedor e cliente, e no contexto da Zona Franca, estes indivíduos tiveram apenas que adaptar as mercadorias transacionadas e ajustar-se aos novos fornecedores, os importadores, e aos novos clientes, os turistas. As mercadorias eram abundantes e a demanda por elas também, o que proporcionou uma oportunidade ímpar e acúmulo de capital. 
Nesta fase da história do estado muitas são as referências ao caráter colonialista e inadequado dos empreendimentos ${ }^{7}$ pois, além de ter favorecido o capital estrangeiro e pessoas acostumadas com a dinâmica de uma Zona Franca ${ }^{8}$, houve denúncias da própria Federação das Indústrias do Estado do Amazonas (FIEAM), como a seguinte declaração: “a renda gerada aqui não fica em Manaus e dessa forma, não promove o aumento da renda local, ficando concentrada nas mãos de empresários que enviam para seus estados ou país de origem, sem sequer realizar investimentos" (CARVALHO apud FIEAM, 2009, p. 110).

Se o perfil das indústrias é "desenraizado", pode-se dizer o mesmo dos mascates. Enquanto eles incorporaram uma nova atitude como resposta relativamente rápida à transformação em curso, o empresariado tradicional local se adaptava gradativamente à nova lógica que exigia a redefinição de toda uma cadeia comercial tradicional. Assim, muitos optaram por alugar seus estabelecimentos às novas pessoas ou empresas que sabiam como atender as demandas dessa concentração econômica.

Ainda segundo o autor, o empresariado local que se formou situa-se numa condição marginal e dependente, e se beneficia sobretudo com o aproveitamento das externalidades promovidas neste período. Na prática, isso significa que os empresários do setor terciário, por exemplo, que não têm incentivos e que comercializam vestuários de origem nacional, se beneficiam do salário dos mais de 100 mil trabalhadores do Pólo Industrial que se converte em consumo. Assim, tanto os incentivados como os não incentivados exibem uma relação de dependência estrutural de modo a participarem todos da construção social da Zona Franca, o que justifica, por exemplo, certos comprometimentos políticos.

Douglas Piza (2012) apresenta um cenário bem instigante do comércio da rua 25 de março em São Paulo operado por migrantes chineses. O autor explora um vetor da mundialização em que as migrações se coadunam com o comércio informal que muitas vezes permitem o atravessamento de fronteiras do Estado e da lei. A circulação mercantil operada por "formigas", "sacoleiros" e "mascates", por exemplo, realiza altas transferências

\footnotetext{
7 Uma crítica clássica à ZFM é tecida pelo jornalista amazonense Márcio de Souza no livro “A expressão amazonense: do colonialismo ao neocolonialismo" (1978), no qual caracteriza o período como de "integração neocolonialista", pela persistência de esforços de modernização no sentido de apagar os traços de amazonidade que distorcem a paisagem seja pelo inchaço populacional, como pelos projetos de urbanização que se preocupa com as comodidades de uma elite minoritária, o que revela a persistência de uma mentalidade conservadora e extrativista.

8 Grupos comerciais com experiência em transacionar bens estrangeiros tinham muito interesse no sucesso do modelo da Zona Franca, assim como grupos empresariais ligados ao turismo interno brasileiro, grupos industriais nacionais, a burguesia nacional ligada ao capital estrangeiro e grupos industriais multinacionais. Os importadores atuantes na época em Manaus podem ter tido relação com as zonas francas vigentes no Panamá, Hong Kong, Miami e na Índia (MENDONÇA, 2013).
} 
internacionais de mercadorias. São trajetórias migratórias por onde passam também produtos, ou rotas mercantis pontuadas por migrantes ou atravessadores. Nesses casos, a “sociabilidade através das redes sociais, dissemina certo tipo de saber 'circulatório' que rende uma autonomia conquistada pelos migrantes - um espaço em que apenas eles são capazes de operar" (PIZA, 2012, p. 32).

$\mathrm{O}$ autor argumenta que as atividades dos chineses ali consolidaram mudanças cruciais no comércio da região, e são responsáveis pela transformação do modo de abastecimento e venda dos produtos com a substituição do circuito paraguaio de sacoleiros para a importação direta e pela proeminência da galeria como modalidade de venda varejista e atacadista. Há indícios de que as novas migrações chinesas têm alta circularidade, a depender da revenda dos produtos a baixo preço importados da China, possibilitada principalmente após as reformas econômicas e as políticas de industrialização do governo de Beijin na década de 1980.

O caso da presença chinesa nos comércios de todo o país alude não apenas aos modos de inserção e adaptação de estrangeiros em frentes de expansão, como indicam um desafio atual para os empresários já estabelecidos no ramo varejista. Pelas ruas do comércio de Manaus a presença chinesa é incontestável. Estes comerciantes transacionam bens com alta procura no mercado por meios exclusivos ou de difícil acesso. Como no passado, muitos comerciantes locais (e alguns palestinos) preferem alugar seus imóveis comerciais aos novos empresários a ter que redefinir suas redes comerciais. A alternativa que tem sido incentivada pela Associação Comercial é a de acordos comerciais com a China, mas nem todos conseguem atender seus critérios.

\subsection{A que se deve o sucesso? Questões em torno das narrativas de acomodação e da produção da "colônia"}

A retrospecção feita por quem narra a imigração ao Amazonas e como se deu a adaptação neste novo lugar pode responder ao interesse de marcar um ato fundante ou, ainda, reconstruir uma "ancestralidade" para fundamentar o sentido de "colônia". Este é o termo para indicar o coletivo de famílias palestinas, o agregado de pessoas que possuem 
interesses em comum". Haja vista que a ideia de "colônia" se fundamenta na sua constituição por famílias "palestinas", nesta sessão apresento não apenas o início das bases materiais que a produziu ("os primeiros anos dos palestinos em Manaus" como dizem os interlocutores) mas também o início de estratégias que permitiram a produção de subjetividades "palestinas".

Neste sentido, proponho refletir sobre o trabalho de mascate, delineando como os dados da literatura traçada nas primeiras seções estruturam a memória destes sujeitos, e observando também como outros fatores são elaborados em suas narrativas. Identifico que a retrospectiva possui o efeito de dar sentido às trajetórias de "sucesso", produzindo o que denomino como "narrativas triunfalistas". As trajetórias de "sucesso" são contadas com a preocupação de adequar as experiências, norteando-as por uma fonte que se encontra para além delas. Neste ponto me inspiro nas considerações de Webb Keane (1997) sobre as narrativas de conversão religiosa numa situação de encontro colonial na Indonésia.

Este autor aponta que os discursos e as crenças sobre a linguagem revelam não apenas os mundos cultural e histórico no qual os sujeitos agem, como também um tipo de agência histórica em que persiste modos locais de reprodução social. As narrativas triunfalistas neste caso servem para construir o sentido da conversão religiosa, e denotam um senso de percepção de transição histórica que demarca uma evidente persistência de conteúdos locais que devem ser "purificados" através de táticas ideológicas. Tais conteúdos são muitas vezes elaborados com pertencentes ao "passado". As narrativas constroem e sedimentam um senso específico da história, que é elaborado também na construção contemporânea de identidades formuladas pela oposição ao passado.

A persistência do "passado" é percebida principalmente no modo como seus interlocutores atribuem a autoridade de suas palavras, que não podem caracterizar a agência pautada simplesmente na ação autoconsciente, pois elas são inseparáveis de uma especificidade histórica das práticas concretas e formas semióticas nas quais está incorporada.

\footnotetext{
${ }^{9} \mathrm{O}$ seu significado não era explicitado, de modo que parecia se tratar de obviedade, assim como quando usavam o termo "terra" para designar a Palestina. O critério para se aferir a "palestinidade" de uma família está ligado basicamente ao reconhecimento de "tradições" culturais palestinas e da vivência da religião islâmica. Um pai ou um filho "palestino" pode não ter necessariamente nascido na Palestina, o que, aliás, é muito comum, mas deve ter ascendência palestina e esforçar-se por manter estas características. Os interesses em comum ou de "colônia" serão tratados no próximo capítulo, quando argumento que outras relações, inclusive as de conflito, também revelam um senso de "grupo". É importante notar que a colônia considera aceitável um palestino casar com uma brasileira, mas repudia com veemência quando se trata de um casamento entre uma palestina e um brasileiro, um dado curioso uma vez que a criação dos filhos é de responsabilidade da mãe, o que supostamente garantiria a transferência de seus atributos, mas que revela, por sua vez, uma ideia patrilinear do parentesco. Esta questão será tratada com mais acuidade no último capítulo.
} 
Com estas considerações, Webb Keane (1997) quer sublinhar que as visões sobre o passado são construídas em retrospectiva, e por isso são simultaneamente um produto do presente e a base para a projeção do futuro.

Desta problemática, Keane (1997) estabelece que naquele contexto, as palavras emanam de uma intenção que possibilita incorporar outros sujeitos à ação. Neste sentido, proponho aproveitar as contribuições de Keane (1997), não para entender as narrativas de meus interlocutores como fruto de uma situação de perspectivas conflitantes, mas para sublinhar que os discursos sobre suas trajetórias adquirem um sentido dentro de um quadro mais amplo da reprodução do coletivo. Tais palavras são prenhes de uma intenção que os possibilita adaptar suas experiências em Manaus com princípios que não foram convertidos à lógica do mercado e aos estilos de vida proeminentes no contexto manauara. É este olhar que pretendo imprimir aos dados que se seguem.

Ao inquirir sobre a migração palestina ao Amazonas, três são os nomes das pessoas apontadas como tendo sido os primeiros palestinos na região: o Sr. Osmar, o Sr. Naim, e o Sr. Ahmed. Estes são reconhecidos pela maioria como os primeiros imigrantes e frequentemente apontados como sendo as principais testemunhas do processo de imigração e formação da Sociedade Árabe-Palestina do Amazonas. Outros, como o Sr. Farid e o Sr. Cid, também são reconhecidos pela mesma autoridade nestes assuntos, e todos estes fazem ou fizeram parte da diretoria da entidade em algum momento, são muçulmanos e contam com idades entre 60 e 80 anos.

O Sr. Osmar (quando chegou em Manaus começou a ser chamado por um nome brasileiro pelo qual todos o conhecem), foi o primeiro de Beni Naim (província da região de Hebron, na Cisjordânia) a chegar a Manaus. Depois de concluir os estudos e de uma rápida passagem pelo exército palestino (naquela ocasião as forças militares israelenses suprimiram o exército palestino, "Israel acabou com tudo", disse), Osmar se viu sem melhores expectativas de emprego na sua região. Havia, à época, uma oportunidade para jovens como ele em instituições públicas do Kwait, para onde decidiu ir "trabalhar para o governo", ocupação que durou 2 anos e 8 meses, quando ele e os demais jovens foram expulsos do país devido às alterações nas relações entre os dois países. 
Figura 1: Vista da cidade de Beni Naim em 2009.

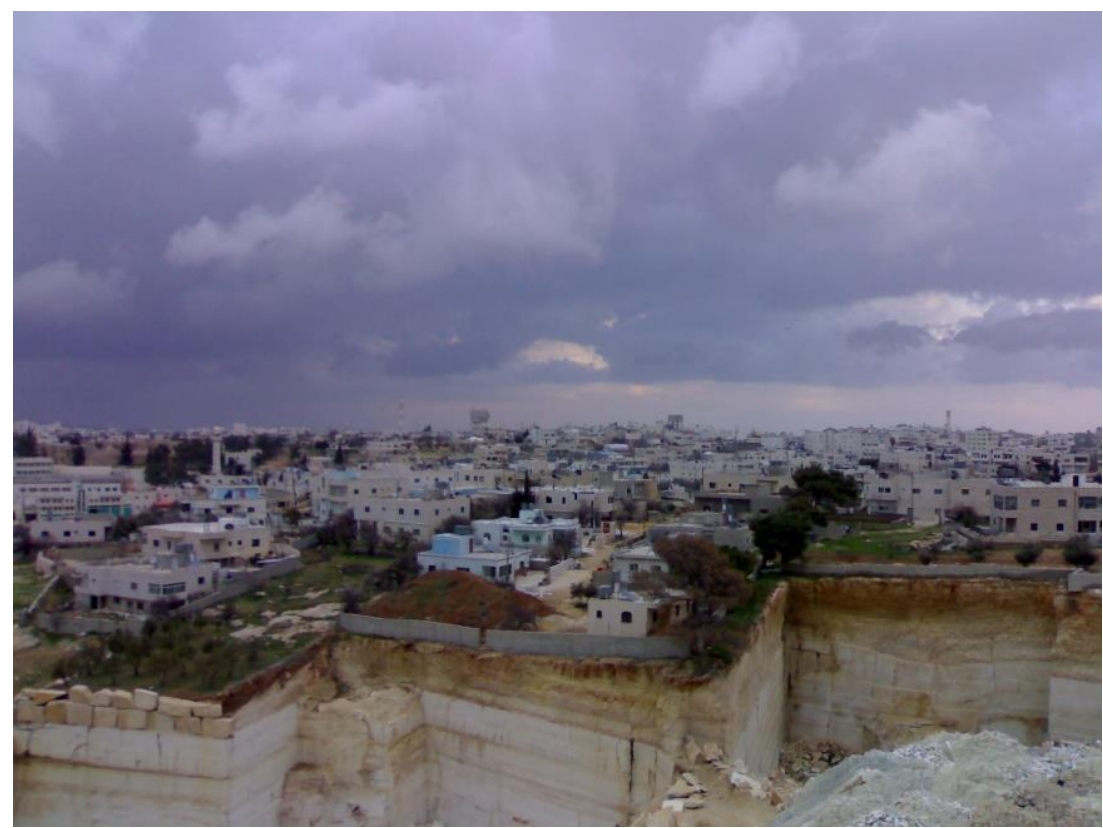

Fonte: http://www.palestineremembered.com/GeoPoints/Bani_Na_im_828/

Figura 2: Localização de Bani Na'im.

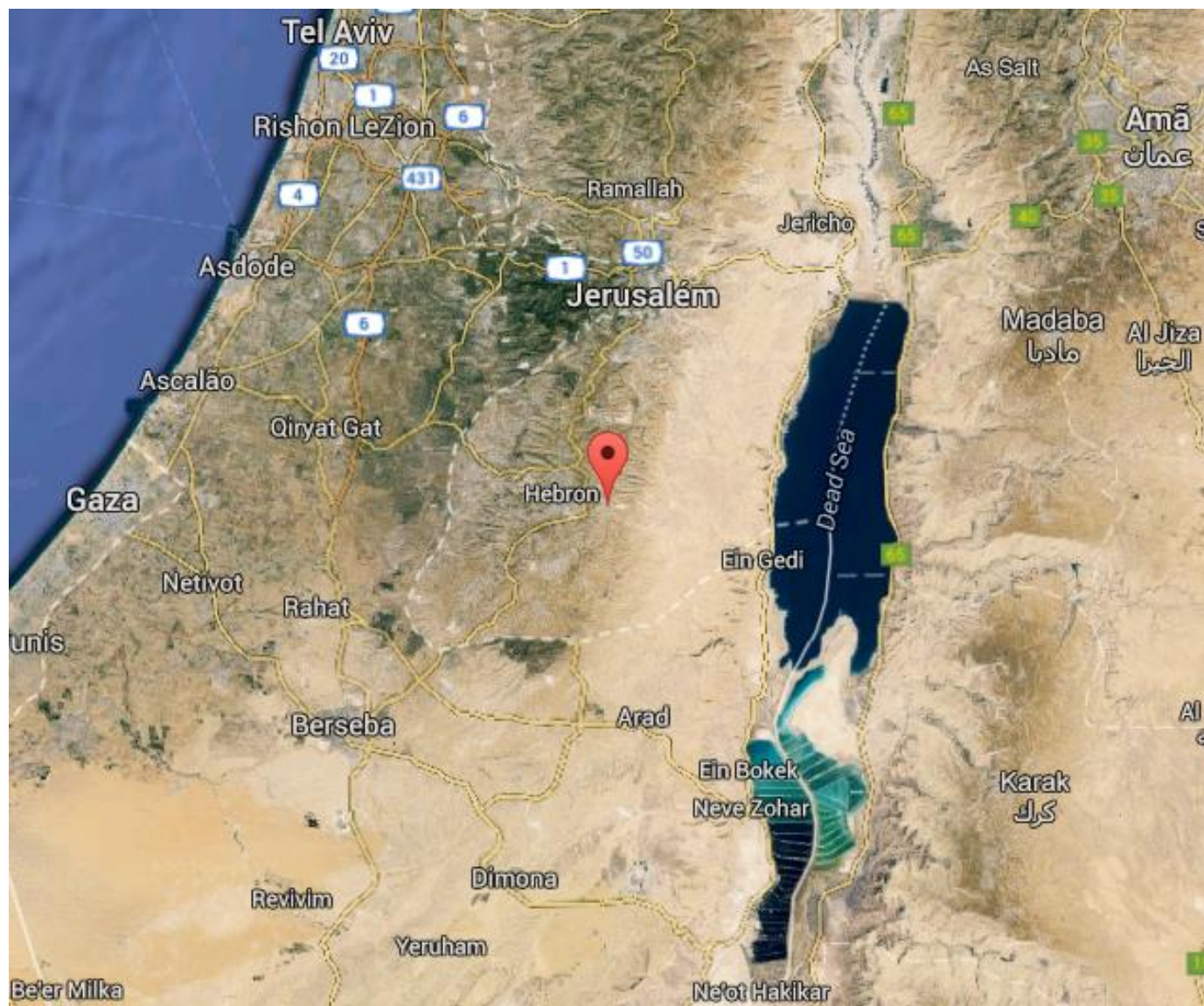

Fonte: Google Earth, 2015. 
Figura 3: Plantação e criação de animais em Beni Naim, 2009.

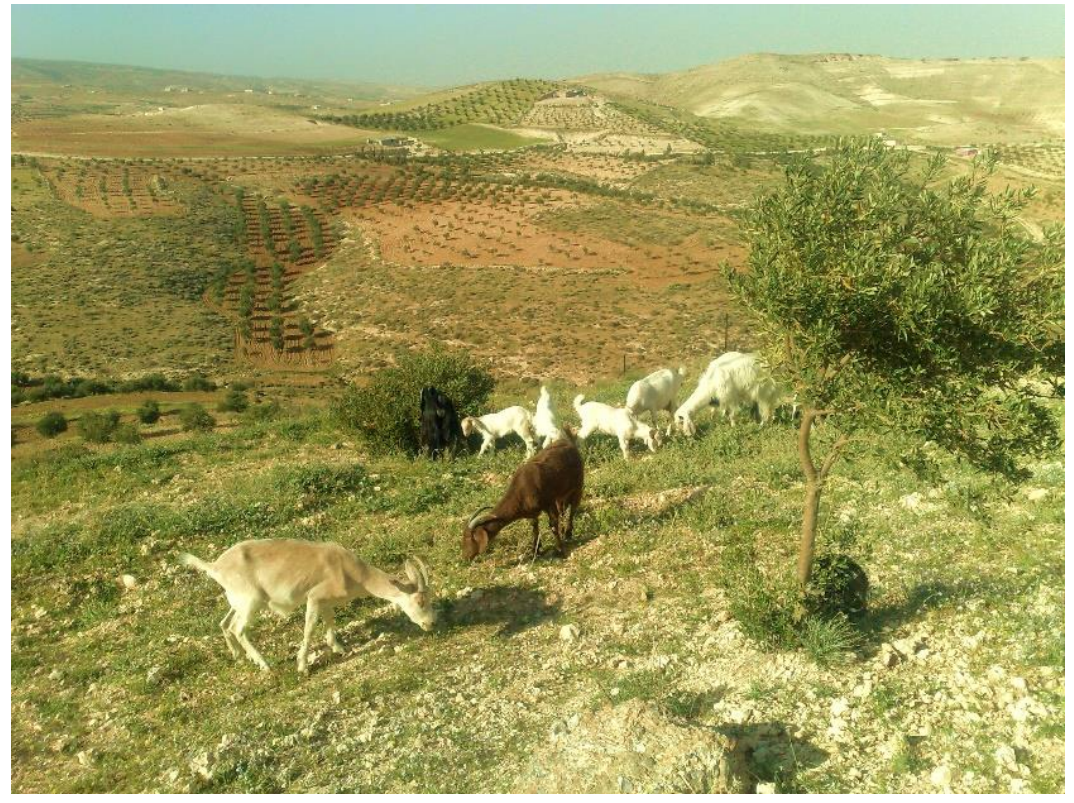

Fonte: http://www.palestineremembered.com/GeoPoints/Bani_Na_im_828/

Sem outra opção, voltou à Beni Naim e após pouco tempo trabalhando na lavoura da família, tomou a decisão de partir para o Brasil, de onde ouvia referências à imensa dimensão territorial e aos projetos de desenvolvimento que anunciavam uma possível absorção de grande quantidade de trabalhadores. Partiu para Beirute, de onde sairia o navio para o porto de Santos com apenas 14 dólares no bolso, e chegou em Brasília em 1961, onde trabalhou no ramo da construção civil. Logo depois abriu um negócio que não logrou êxito, pois segundo ele, haviam muitos palestinos, libaneses e outros imigrantes na mesma situação que a sua, concorrendo pelas mesmas atividades. Em 1964 migrou para Manaus, onde achava que pudesse conseguir algo melhor; Foi "mascatear".

Depois de alguns anos neste circuito o Sr. Osmar consegui comprar a própria loja de confecção, mais tarde pensou em construir uma indústria de confecção, mas não entreviu condições para tal. Na ocasião, no ano de 1978, encontrou à venda uma indústria de papel falida e resolveu arriscar no ramo. A esta altura, já estava decretada a Zona Franca de Manaus mas o Sr. Osmar não comentou o fato. Inicialmente foi proprietário da indústria com outros dois irmãos (um deles é o Sr. Farid), que desistiram da Sociedade antes que o projeto começasse a dar lucro. Atualmente um dos filhos do Sr. Osmar é quem administra a fábrica, tendo conseguido um contrato de vendas de caixas de papelão com a Samsung, uma corporação transnacional do ramo da tecnologia da informação, que possui montadoras na área industrial da Zona Franca. 
Os seus primos, Naim e Ahmed, também chegaram a passar por Brasília, mas atenderam ao seu chamado em Manaus para onde seguiram com os outros dois irmãos de Osmar. Mas o primeiro interlocutor a me contar detalhes dos anos de adaptação no Brasil foi um dos irmãos de Osmar, o Sr. Farid. A conversa com Osmar se deu depois, por insistência do seu genro Omar que fez questão de incluí-lo na minha lista de interlocutores sobre "os primeiros anos dos palestinos em Manaus", como entendeu Omar. O Sr. Osmar estava muito debilitado na ocasião da conversa, de modo que não pude registrar uma narrativa grande e com mais detalhes. Mas é importante registrar as circunstâncias deste encontro, que já anuncia algumas das clivagens apresentadas mais adiante.

A conversa com Farid se deu de outra maneira, num dia em que decidi procurar os comerciantes palestinos da rua Marechal Deodoro sem a indicação de Omar. No dia da conversa com Farid, eu me encontrava na loja de dois sobrinhos seus: Fauzi e Fuad, que viabilizaram o encontro porque, segundo eles, Farid era o mais indicado para tratar dos assuntos da colônia. Nesta ocasião pude perceber que Farid era alguém com uma linguagem comum no nível da representação formal daquele coletivo de palestinos, alguém que mantem inclusive relações públicas nas quais se incluem iniciativas políticas e sociais para além dos interesses estritamente "palestinos". Trata-se de alguém cujas ações econômicas e políticas se assemelham em muitos aspectos ao do empresariado local, dependente da estrutura promovida pelas políticas incorporadas na Zona Franca de Manaus.

Grande parte da narrativa de Sr. Farid entrelaça histórias diversas, de modo que o valor referencial do seu discurso incorpora vários sujeitos, o de um "nós" palestino, um "nós" manauara, e de um "nós" brasileiros. Poucas vezes seu discurso tem referência em primeira pessoa. Diante da proposta de "contar uma história", decidi não interromper sua narrativa e percebi uma boa oportunidade para gravá-la, lhe dirigi o pedido que foi admitido prontamente. Poucas foram as intervenções que fiz, geralmente para esclarecer alguma ideia ou para desenvolvê-la.

Farid: E fomos crescendo, gente e economicamente. Como a Palestina, naquela época, já vive sob domínio israelense militar, dos mais bravos do mundo, tínhamos obrigação da gente começar a ajudar a família lá. Criamos uma "Sociedadezinha", mandar, por exemplo, 30 mil dólares pra comprar medicamento pra Gaza, 20 mil dólares pra comprar um SOS, porque havia conflito diário sobre essa ocupação. Então tínhamos feridos que não tinha como ajudar eles a levar eles ao hospital, então mandamos carro SOS fizemos pequenas escolas, fizemos uns laboratórios, é, UPP, atendimento aos feridos, Unidade de Pronto Socorro. 
Assim começa a chamada Sociedade Árabe-Palestina do Amazonas, o que pode ser caracterizada como a primeira fonte de ativação formal de um sentimento de coletividade, ou de produção de uma subjetividade palestina de nível coletivo. A “colônia”, portanto, pode ser esta entidade evocada para estes assuntos, e que ajuda a reforçar uma sensibilidade para questões referentes à nacionalidade, uma vez que outras obrigações com pessoas da "terra" não acabam com a emigração. No nível da representação da "colônia", como é o caso deste interlocutor, os sinais de prestígio se revelam em discursos bem treinados e acostumadas a se "pronunciar" sobre assuntos que dizem respeito aos palestinos.

O contato com Farid me fez ver posteriormente o quanto certas vozes, incluindo a sua e dos demais interlocutores que falam em nome da "colônia", estão distantes do nível das práticas comerciais, dos acordos e das relações para estes fins. Tais narrativas apresentam a versão de uma "colônia" harmônica em que todos são irmãos, mas na atividade comercial estes palestinos se revelam tenazes concorrentes. Estes discursos têm importância no sentido de revelar posições, prestígios e autoridades no nível da representação de um coletivo de pessoas, sejam elas empresárias, palestinas, imigrantes, ou tudo junto. Trata-se de estratégias inventadas por estes sujeitos para efetivar uma ideia de "colônia palestina", com noções tangíveis como as metas de "grupo" e interesses comuns bastante claros, como o apoio à "causa palestina" e a observação dos preceitos islâmicos, metas organizadas em nome da colônia e que produzem efeitos públicos e políticos.

Percebo as impressões de Farid a partir deste lugar, que é o lugar onde estive no início da minha pesquisa, e que começa pelas narrativas de viagem e de incursão nos desafios que a vida em Manaus lhes impunha. Na linha do seu pensamento, Farid estabelece como início da emigração palestina para o Brasil o ano de 1948, ano de promulgação do Estado de Israel. Por mais que eu expusesse meus interesses pelo processo migratório e pela atividade no comércio (e outros interesses que vieram se delineando com o tempo em campo), eu sempre ouvia comentários a respeito da ocupação israelense por parte de homens atuantes na representação da Sociedade. A impressão é a de que o ano de 1948 funciona nestes discursos como um elemento para se pensarem como "palestinos no Brasil", e que o termo "exílio" parece ter efeito amalgamador.

No Brasil, Farid ressalta que compuseram parte da mão de obra para a construção da capital: "nós participamos da construção de Brasília", e terminada a construção, decidiram “tentar o Amazonas", por volta dos anos de 1961 e 1962. Chegando lá, estes imigrantes se referem àquela fase da cidade como sendo de uma economia fraca, baseada na exportação de juta (uma espécie vegetal muito utilizada na confecção de paneiros e outros utensílios), borracha e castanha, de modo que a única opção era mascatear: 
Farid: Manaus era o estado mais pobre do Brasil. Não tinha quase nada, a nossa economia restrita ao funcionalismo público municipal, estadual e federal, e a nossa produção, agricultura nossa, era reduzida em três produtos: a juta, borracha e castanha, que hoje chama castanha-do-pará, mas é amazonense né. O resto a gente importava dos outros estados brasileiros pra gente sobreviver. Até hoje, até hoje Manaus só produz $6 \%$ do que ela consome. Por que isso? A nossa terra é infértil, tá! A nossa terra é areal, e pra gente tornar ela fértil, pra aceitar agricultura seria muito caro, mais caro do que a gente importar esses produtos. Começamos, sabe que toda imigração começa do zero, tá? Então qual é o caminho pra gente poder dar um passo era mascate. Mascate é aquele que carrega a mala, e vai batendo porta a porta vendendo o produto, era mais confecções, e nós não tínhamos know how e nem capital pra partir pra outra coisa. Então a gente chegava pros atacadistas, e arrume uma mala de mercadoria, eu vou vendendo e vou te pagando. E começou assim. Até isso, foi até 1966, a gente tava querendo partir daqui e voltar pra São Paulo porque não dava mesmo.

Eu: Estavam sem capital?

Farid: É, capital e não tem venda, não tem recurso. O funcionalismo o salário dele é pra comer, então não tem sobra de dinheiro. Não tem agricultura, não tem indústria, não tem nada.

Eu: Então não tinha demanda para os produtos de vocês.

Farid: Demanda é claro que eles têm mas a preferência era comer, né. Então saiu conversa sobre abertura de Zona Franca de Manaus, que acendeu uma esperança pra gente. Então vamos segurar essa imigração e esperar o quê que vai dar essa Zona Franca.

$[\ldots]$

Farid: E porque confecção? É, crédito tem, dinheiro não tem, know how não tem, todos saímos de lá, do banco do colégio direto para a imigração. Então não temos know how de indústria, não temos know how de nada, a não ser de compra e venda. Se custa 5, vende por 7, tu tá ganhando 2, gasta 1 e fica 1 . Então essa era a nossa matemática, era a nossa força, era o nosso empreendimento só dentro disso.

Importante notar que ele e os demais optaram pela rua Marechal Deodoro porque à época possuía os valores mais acessíveis para compra e aluguel de imóveis comerciais, não era, portanto, a rua mais procurada pelos interessados em confecção. Cid revela que ele e os demais palestinos que já se encontravam na área desenvolveram algumas estratégias para atrair os clientes que iam longe nas ruas de cima especializadas em confecção, como o bater das mãos. De tudo faziam para chamar a atenção dos clientes, até sacrificar um artigo de venda. Conta Cid que era comum eleger um produto que geralmente não custava muito ao vendedor e que costumava sobrar, para oferecê-lo a um preço quase de custo mediante a compra de outro produto pelo preço normal.

Apesar do sucesso empresarial de muitos ${ }^{10}$, houve também casos de tentativas infrutíferas dos conterrâneos na atividade comercial manauara, de pessoas que acabaram voltando para a cidade natal. Diante disso, os que atingiram a colimada "progressão de vida" com a construção de fortuna, apresentam uma curiosa versão sobre este sucesso. Não fossem

10 Farid, que é um dos representantes da Sociedade Árabe-Palestina do Amazonas, declarou que todos os palestinos em Manaus têm rendas que correspondem no mínimo à classe média no Brasil. 
os imigrantes árabes e cearenses, a economia do Amazonas não seria como é hoje, segundo o Sr. Farid. Parte disto se deve ao fato de que, como expôs, o amazonense é derivado de caboclo e índio, duas "raças preguiçosas". Porém, o "crescimento" quantitativo e financeiro da colônia palestina também se deve ao crescimento econômico de Manaus, segundo Farid:

Farid: Isso nos anos 70. E a imigração palestina começou a crescer internamente, comercialmente, não é outra coisa. Aí 1978 iniciamos, ou, ficamos olhando para a indústria. Crescemos, estamos com dinheiro e queremos ultrapassar esse negócio de confecção, vender camisa, comprar camisa. Abrimos, abrimos não, compramos uma empresa de caixas de papelão falida e reerguemos ela, eu e mais dois irmãos meus. Hoje ela é a maior indústria de base do Estado do Amazonas. Ela recicla, produz o papel, produz caixa, produz papel higiênico e derivados, e chegou a ter 800 funcionários, e fomos. Cresceu, graças à Deus, hoje tá na mão do meu irmão, nós saímos para o comércio e ele ficou na indústria. Hoje graças à Deus podemos dizer que somos considerados classe média, média e média alta e, vencemos, juntos com todos que trabalharam nesse Estado, porque quem não trabalhou ficou. $\mathrm{O}$ amazonense é derivado de caboclo com índio, entendeu? As duas raças são preguiçosas. Graças à imigração cearense, nordestina, como fizeram para São Paulo, Rio de Janeiro e fizeram no Amazonas. E o distrito industrial que nós começamos e paramos, foi crescendo, foi crescendo, aí o governo federal começou a adotar umas medidas porque olha, se você vai fabricar televisão ou montar televisão, então os parafusos, placa, isso e aquilo tem que ser brasileiro, o tubo, antigamente a televisão era em tubo, o tubo era importado, então temos que adequar a indústria amazônica com $50 \%$ dos produtos nacionais.

Mesmo tendo encontrado "tudo pronto" ", os imigrantes que vieram para trabalhar com os parentes que haviam se estabelecido na década de 1970 também tiveram que trabalhar pelo seu próprio espaço na atividade comercial e apresentam uma versão desse processo. A chegada dos filhos e sobrinhos dos primeiros imigrantes, que incluo nesta seção, se deu por volta de meados da década de 1970 e na década de 1980. Além de referências às características intrínsecas ao "sangue árabe", ou ao tino para o comércio serem recorrentes, a dedicação quase que exclusiva ao trabalho árduo sem gasto conspícuo unidos à perspicácia, muitas horas de solidão, alimentação frugal, poupança e acumulação, marcam as narrativas triunfalistas. Cid traz a sua versão deste momento:

Cid: Quando abriu Zona Franca de Manaus começamos a fazer serviço de compra de material e vendendo para os passageiros que vem lá do sul, turistas né?

Eu: Mas o senhor diz “começaram”, quem começou? O senhor e mais quem?

Cid: Alguns que não tinha lojas, alguns que realmente era mascate não tem loja, então são, uns 20 ou 30 pessoas que estavam fazendo.

\footnotetext{
${ }^{11}$ Foi essa expressão utilizada por um sobrinho e um filho de Farid, beneficiados pela ótima condição econômica conseguida por este último que pôde lhes oferecer boas condições para a inserção na atividade comercial. No capítulo seguinte, exploro com mais detalhes sobre como funciona o trabalho entre parentes, a troca de favores, alguns usos do dinheiro e suas implicações.
} 
Eu: Nem todos palestinos então.

Cid: Não, nem todos. Existiu libanês, existiu sírios, existiu iraquianos, era uma mistura, não era só palestino.

Eu: E os amazonenses?

Cid: Amazonense não trabalhava nisso.

Eu: E essas mercadorias vinham de onde?

Cid: Essa mercadoria, é que tinha importadores aqui, a gente comprava dos importadores aqui, entendeu? Nós não importava mercadorias porque não tinha o porte pra importar, tá entendendo?

$\mathrm{Eu}: \mathrm{E}$ os importadores eram quem?

Cid: Era, eu não me lembro mais os nomes mas era alguns chineses, judeus também, tá entendendo? E indianos. Eles que importavam e a gente comprava deles e vendia. É, esse material eletrônico, entendeu? Mas trabalhamos uns três anos, depois eu abri uma loja né? Aí cada um começou a abrir uma loja num bairro e passou pro centro. É assim.

Youssef (62 anos) que chegou através de Farid, seu tio materno, declara que: "tem gente que tem preguiça, não tem sorte na vida, tem gente que é analfabeto e não tem aquela visão, entendeu? Não tem aquela coisa, não tem como planejar, até acha dificuldade na língua, não tiveram sorte". Para ele, o objetivo da imigração foi o de progredir na vida pela aquisição de fortuna, e explicita condições individuais para a consecução deste objetivo. Farid explicita uma das práticas fundamentais neste ambiente:

O cliente é o nosso patrimônio, essa é a meta nossa. É o cliente em primeiro lugar, cliente em segundo lugar, cliente em terceiro lugar. Sem cliente a gente não vive, então a gente dá tudo para agradar o cliente. Porque esse é o patrimônio de uma empresa, é o consumidor.

O Sr. Fauzi, que me recebeu na conversa com o Sr. Farid, que é seu tio, falou vigorosamente da adaptação em Manaus, facilitada porque sua língua materna, o árabe, é um idioma que exige, mais do que qualquer outro, uma combinação de habilidades que ultrapassam a simples dicção, pois exige a emissão de sons fortes que dependem, por exemplo, do disciplinamento do diafragma. Sendo assim, um falante do árabe estaria apto para aprender qualquer língua. Além deste fator, a necessidade unida com a vontade de aprender, da garra (“que está nas veias do árabe”), foram igualmente decisivos no processo de adaptação ao novo contexto.

Outro motivo que concorreu para o seu sucesso foi o fato de sempre ter agido e continuar agindo conforme as leis corânicas, demonstrando bom caráter e ganhando a confiança das pessoas com quem se relacionava no ambiente de trabalho. No início, assim como tiveram quem o ajudasse a "subir", também tiveram os que o colocavam "pra baixo". 
Este interlocutor declara que o fato de ser conterrâneo ou falante do árabe não implica necessariamente numa expectativa de ajuda. Para ele, os negócios pertencem às famílias compostas por pai, mãe e irmãos, que "tocam seu próprio barco", porque apesar de serem todos primos, todos concorrem entre si por ocuparem o mesmo ramo no comércio.

Nenhum destes interlocutores declarou que obtiveram alguma vantagem junto aos demais imigrantes oriundos de países árabes; o Sr. Farid expressa, inclusive, que estes "não ligavam" para eles, e fala de uma espécie de desprezo. Mas foi comum entre esta geração de migrantes o casamento com mulheres de origem árabe. Em campo conheci pelo menos quatro casos disso, o do próprio Farid, seus três irmãos e o primo Cid. Por mais que realmente isso não tenha significado alguma vantagem na atividade comercial, tal fato demonstra a atitude tomada frente à população manauara, mantendo-se fiéis a uma exigência de afinidade árabe no intuito de garantir certos atributos comportamentais, valorizados por eles.

A mulher brasileira e não educada dentro dos princípios que elegem como sendo “árabes" não seria a parceria ideal para eles que intencionavam produzir uma família "árabe" em Manaus. É comum ouvir relatos de que essa geração "mandava buscar" mulheres da palestina para se casarem aqui, ou que os próprios homens iam, como foi o caso do Sr. Youssef, casavam lá e traziam suas mulheres para junto de si. Da mesma forma acontece em relação ao recrutamento de funcionários pois, com exceção dos vendedores e em alguns casos de gerentes, os funcionários e sócios também são palestinos, filhos ou sobrinhos dos proprietários, pessoas em quem confiam e de quem podem exigir condições específicas ${ }^{12}$.

O critério do recrutamento é uma prioridade atendida na atividade comercial, ele possibilita reciprocidades e revela responsabilidades com a família, expressas na obrigação de “ajudar”. Há uma assertiva curiosa do Sr. Cid que também adquire sentido neste contexto: “as pessoas trabalham lá fora e alimentam a família lá dentro, se sobrar dinheiro não aumenta o comércio, ou constrói uma casa melhor ou coloca o filho para casar". Assim, o acúmulo de capital pode atender primeiramente as exigências da reprodução familiar, o que se torna compreensível uma vez que a própria possibilidade de migrar, a causa destes lucros, acontece por meio da convocação de parentes e tem como efeito a reprodução da família.

A frugalidade, o trabalho árduo, a poupança e a acumulação com vistas às gerações futuras são, como bem aponta Rosana Machado-Pinheiro (2007), comuns a muitos migrantes. As diferenças residem, portanto, no sentido atribuído a essas condutas que, no seu caso de pesquisa junto a comerciantes chineses, revelam a retomada de uma ética filosófica/religiosa

\footnotetext{
${ }^{12}$ As condições para os acordos comerciais e a questão matrimonial serão tratados nos próximos capítulos.
} 
construída na condição de imigrantes. No caso apresentado pela autora, o enriquecimento não é um fim em si mesmo, mas o resultado de uma vida equilibrada, e isso destoa do comportamento na própria China, que assiste a um florescimento do consumo alvo de preocupação pelo próprio governo.

O que faz um "chinês" fora de seu país de origem é justamente a condenação do consumo em si e aqui revela-se uma implicação importante, que para muitos estudiosos da imigração pode ser entendida pela noção de diáspora, principalmente no que tange ao resgate de valores "tradicionais". No caso dos meus interlocutores, percebo que a noção de diáspora também tem efeito pois, ainda que se atribua grande importância para a acumulação de bens, os meios empregados são sempre "justificados" como legítimos, "limpos" e adequados aos preceitos islâmicos, como expressa o discurso de Fauzi. A necessidade de se investir na família ou a verbalização dos meios lícitos no processo de acumulação pode funcionar também como uma justificativa moral para a atividade que evoca muitas suspeitas.

Mas os palestinos em Manaus, marcados pelas implicações da diáspora, podem revelar certos comportamentos, declarados ou não, com significados compartilhados. O próprio fato de superestimar atribuições individuais no processo de enriquecimento, valorizando o "trabalho", indica uma referência de símbolos de prestígio que tem efeito entre seus pares, ainda que se assemelhe à lógica capitalista e empreendedora geral. Apesar de não verbalizadas, o modo de organização das empresas palestinas, que se confunde com a unidade doméstica, e a reprodução no comércio, é um fator marcante para a visualização do aspecto de "colônia", além de outras condutas que revelam semelhança diante das situações enfrentadas em comum.

Vale citar aqui um caso em que a conservação e o alargamento de negócios mantidos por estrangeiros dependem do background incorporado nessa condição, ou seja, das particularidades trazidas na "bagagem" aliadas aos modos de enfrentamento da nova realidade. O caso é o dos comerciantes indianos sunitas em Moçambique, estudados por Anabela Soriano Carvalho (2004). Segundo a autora, foram fatores próprios da organização social destes imigrantes bem articulados com as novas disposições econômicas que possibilitaram a superação dos desafios impostos pela difícil situação econômica de Moçambique após a independência, entre 1975 e 1994.

O recrutamento dos funcionários dentro da própria rede de parentesco também se dá no caso estudado pela autora. Essa escolha, além de garantir mão-de-obra barata, também possibilita a reprodução do ofício, bem como a construção de uma rede de influências já que a fidelidade é garantida pelo clientelismo. Associados a estas características, a mobilidade 
geográfica interna e externa de que usufruíam os indianos ajudou a promover o reconhecido lugar que ocupam na economia do Moçambique atual. Estes comerciantes se mantiveram nas fronteiras entre a produção e o consumo, muito adequada ao seu tipo de mobilidade e à instabilidade dos fluxos das mercadorias.

É para explicar situações como esta, que autores como Maja Frykman (2004) defendem a aplicação da perspectiva transnacional. Para a autora, a identificação da situação de "diáspora" deve figurar nos casos de estudos etnológicos em migração laboral, pois apresenta muito potencial em termos de benefícios teóricos, já que possibilita a percepção de como a vida social responde por processos globais. A noção de refugiado, por exemplo, não é apenas um termo legal, mas implica uma série de sentidos nos discursos dos sujeitos sobre suas experiências, circunstância na qual a noção de diáspora pode assumir um discurso eminentemente político.

A ideia é a de considerar mais à sério que as ações, as decisões e as identidades são negociadas a partir de redes de relações que as conectam simultaneamente em redes que ligam dois ou mais estados-nação. Nesse sentido, o imigrante (como uma categoria de pesquisa), pode ser conceituado como vivendo em mais de um contexto nacional. Trata-se de considerar também o que alguns autores cunharam de transnalization from below, e de unir o termo “transnacional” à ideia de "diáspora", no intuito de promover

[...] an analytical framework that is suitable for reconsidering the meaning of locality and making visible the relational nature of some contemporary economic, social and cultural processes that connect some people in certain localities (FRYKMAN, 2004, p. 79).

O termo "diáspora" evoca, em geral, traumas coletivos característicos de comunidades em exílio, mas o uso extensivo do termo e o consequente alargamento conceitual resultou em confusões analíticas e, por esta razão, Frykman defende o emprego do termo "diaspórico", ao invés de "diáspora", porque faz referência a um processo identitário, servindo como um adjetivo para sua caracterização. Ao empregar a palavra "diásporico" não se pretende apenas representar ideias sobre identidades grupais, mas também o compromisso com certas formações sociais, eventos e projetos. A perspectiva da autora é informada pelas práticas transnacionais de percepção de si entre imigrantes laborais refugiados em sociedades ocidentais contemporâneas.

Se o termo "diáspora" tem o potencial de promover condições experimentais para a formulação sobre identidade, lugar, localidade e pertencimento para incluir processos globais, a antropóloga Nina Glick-Schiller (s/d) propõe o termo "diasporic cosmopolitanism”, como 
ferramenta para dimensionar uma mutualidade situada entre pessoas com background migrante no contexto urbano. Nas palavras da autora, o termo "can be defined as the sociabilities formed around shared practices, outlooks, aspirations and sensibilities - however partial, temporary, or inconclusive---that emerge from and link people simultaneously to those similarly displaced and to locally and transnationally emplaced social relationships" (Glick-Schiller, s/d, p. 3).

Sua perspectiva tenciona dimensionar as sociabilidades diárias através das quais os imigrantes constroem sua vida urbana, o modo como as experiências de deslocamento são caracterizadas como "fora do lugar" ou como elas participam da vida urbana com a criação de espaços e movimentos sociais em aspirações compartilhadas. Sendo assim, o termo busca dar conta dos múltiplos compartilhamentos, das múltiplas posições às quais o indivíduo está inserido, incluindo família, amigos, ou, trazendo para o ambiente desta pesquisa, os próprios concorrentes, parceiros e demais indivíduos atuantes no comércio, bem como todos os indivíduos/ interesses que essa atividade pode despertar.

Sobre este aspecto situo alguns comprometimentos políticos observados em campo, relativos a dois temas básicos: a defesa do projeto Zona Franca de Manaus e a "causa palestina". Farid declarou com orgulho que a Sociedade Palestina de Manaus foi a única a promover viagens de políticos e jornalistas brasileiros para a Palestina. Mas o trânsito de políticos entre os dois países é relativamente intenso e em alguns momentos viabilizado pelo conjunto dos palestinos no Brasil. Exemplo disto foi a famosa vinda do então presidente da Autoridade Nacional Palestina (ANP), Yasser Arafat, em outubro de 1995. Na ocasião, Yasser Arafat foi recebido no Senado Federal pelos senadores Bernardo Cabral do Partido da Frente Liberal do Amazonas (que em 2003 passou a se chamar Democratas-DEM), Teotonio Villela do Partido da Social Democracia Brasileira (PSDB-Alagoas), Benedita da Silva do Partido dos Trabalhadores (PT-RJ), Eduardo Suplicy do PT-SP, e pelo senador Ney Suassuna do Partido do Movimento Democrático do Brasil (PMDB-PB).

Outros momentos de articulação para a sensibilização com a causa palestina se fizeram sentir no Congresso, com o pronunciamento do senador João Pedro do PT do Amazonas em 2009, no qual relata a viagem feita à Palestina e à Cisjordânia e pede a articulação do Brasil junto à Organização das Nações Unidas (ONU) para um movimento de solidariedade ao povo palestino. Na ocasião de uma conversa com o Ministro da Agricultura da Palestina, João Pedro também aventou a possibilidade de canais de cooperação agrícola entre os dois países, e aponta as colaborações já existentes como a construção de um complexo esportivo e escolas na Palestina, e de uma praça pública no centro de Ramallah: 
Atendendo ao convite da Associação Árabe do Amazonas [...] ingressei em Amã, capital da Jordânia, no dia 21 último, onde fui recebido pelo Embaixador brasileiro naquele País, Fernando José Marrone, e o Conselheiro Henrique Luiz Jenné, que, em rápidas palavras, narraram as dificuldades que por certo encontraria para entrar e conhecer a Cisjordânia. Cumpridas, finalmente, as formalidades impostas pelas autoridades israelenses para entrar na Cisjordânia, lá ingressei em companhia do Secretário da Embaixada brasileira na Palestina, o Sr. Cláudio Leopoldino - e quero dizer da minha alegria em constatar um escritório do Itamaraty lá na Palestina, na cidade de Ramallah. Como dizia, no dia 23, entrei, então, na Cisjordânia, ao tempo em que me dirigi à cidade de Bani Nain (Bani Nain quer dizer filhos de Nain), na região de Hebron, onde estava sendo esperado por irmãos palestinos, entre os quais figuravam vários filhos de Bani Nain que moram e labutam no Estado do Amazonas. Eles são palestinos, filhos de Bani Nain, uma cidade de 25 mil habitantes, que, por conta dos conflitos, migraram para o Brasil, moram em Manaus, trabalham em Manaus e voltam quase todos os anos para passarem o período de suas férias lá na Palestina. Afigura-se importante registrar, Sr. Presidente, que foi em Bani Nain que presenciei uma das mais absurdas expressões do holocausto que se abateu sobre o povo palestino. Se não fosse pouco o confisco de terras, a destruição de lavouras e toda sorte de humilhação em nome do sionismo, Israel controla $80 \%$ da camada freática da Cisjordânia - controla a água onde vivem os palestinos - e, via de consequência, este recurso natural, que deveria abastecer a população e os setores agrícolas, comercial e industrial, é cotidianamente controlado. Soma-se a esse quadro já alarmante a crise no tratamento da água, que também é limitado por Israel. Inobstante o alerta da Organização Mundial de Saúde de que o esgotamento e a deterioração das camadas subterrâneas palestinas são muito maiores em decorrência da destruição das estruturas hídricas e das redes de saneamento pelos bombardeios ocorridos em diversas regiões do país. Fazendo o contraponto com essa realidade, temos, em Bani Nain, um povo feliz, um povo corajoso, esperançoso, que ainda chora seus mortos, a exemplo do Sr. Abu Nabi Manasrah que teve seu filho, de tenra idade, aos 16 anos, executado pelo exército israelense, quando o mesmo encontravase em companhia de um amigo na área externa de sua residência. Esses dois jovens, $\mathrm{Sr}^{\mathrm{a}} \mathrm{s}$ e Srs. Senadores, foram mortos, assassinados, a partir de um helicóptero, localizado a 20 metros de altura. Surpreendeu-me, naquela cidade, o poder de superação e resistência dos homens, mulheres e crianças que ali vivem, das autoridades que labutam na construção e reconstrução do seu espaço, com vistas à criação do democrático Estado Palestino. Ilustro dita afirmação com o que vislumbrei nas visitas às obras de prédios públicos de Bani Nain, acompanhado do prefeito da cidade. (Trecho do pronunciamento do Senador João Pedro no Senado Federal. Diário do Senado Federal. Agosto, 2009).

Segundo Farid, ocorreram e ainda ocorrem coalizões entre a representação da colônia e agentes políticos quando estes demonstram interesse em apoiar a causa palestina. Para estes assuntos, este interlocutor revela ser esse o principal motivo de apoio partidário pela colônia, em nome de seus representantes, que esperam receber em troca atitudes como a de João Pedro. Embora faltem exemplos mais palpáveis sobre os recursos transacionados nestas circunstâncias e se eles são trocados pela representação de outros interesses, aproveito para inscrever esta situação dentro de uma perspectiva em que processos políticos transinstitucionais se constroem sob as bases das relações interpessoais (BARNES, 1969). Dessa forma, os esforços empreendidos no sentido de conquistarem espaço ou de moverem fluxos também incorporam estratégias de coalizões políticas e/ou partidárias por meio de trocas. 
O Sr. Omar, por exemplo, compartilhou comigo os recortes de jornais locais que coleciona sobre assuntos que o mobilizam. São notícias das diversas passeatas promovidas pela colônia de Manaus, dos conflitos que ocorreram na Palestina e que tiveram repercussão ali, e das vezes que foram publicadas notícias suas, como presidente da Associação de Lojistas da Marechal Deodoro ou sobre seus novos empreendimentos e sua participação na expansão do circuito lojista. O Sr. Omar também guarda uma notícia referente à viagem de Roberto Méndez, um famoso apresentador da TV local, que foi à Palestina também acompanhado de um palestino residente em Manaus. Omar organiza outras viagens tanto daqui pra lá como de lá pra cá, alguns interlocutores contam que os brasileiros que vão na Palestina nestas circunstâncias são exibidos em comitiva, juntamente com quem promoveu a viagem.

Segundo o Sr. Farid e o Sr. Omar, o PT também tem acolhido de modo mais aberto as demandas pela solidariedade ao povo palestino. Mas o projeto político da Zona Franca recebe largo apoio em vários programas políticos do Amazonas. Foi o atual senador Omar Aziz pelo Partido Social Democrático do Amazonas (PSD-AM), e antigo governador do Amazonas, quem articulou a provação da PEC (Proposta de Emenda à Constituição), que prorrogou por mais 50 anos a vigência da Zona Franca. O senador Omar Aziz é filho de palestino e, embora não tenha vínculo com a cidade de Beni Naim, tem relações bastante estreitas com a colônia da qual recebe apoio declarado.

A partir deste foco, definem-se as situações que produzem sensibilidades e sociabilidades entre pessoas com distintos backgrounds, no compartilhamento não apenas de espaço, mas de tarefas e desejos, e ao mesmo tempo a sensibilidade inversa, da sociedade envolvente que precisa ajustar-se a novas demandas e dinâmicas promovidas por indivíduos que já modificaram a paisagem urbana e que produziram mais conteúdos cosmopolitas. Neste sentido, é mais apropriado entender suas escolhas dentro desse encontro de perspectivas do que nos registros culturalistas que congelam valores e prescrições sobre a vida comum.

Dito isto, é importante reter alguns aspectos fundamentais para as análises que construo nas sessões seguintes. Em primeiro lugar, reforço que a "colônia" tem um sentido construído em alguns discursos, principalmente nos dos representantes da sociedade ou de outras pessoas que se sentem na obrigação de sustentar esse sentido. Tal sentido se constrói de maneira formal pela instituição oficial de representação, e pelas retóricas de articulação das experiências em Manaus com princípios religiosos, relativos às obrigações com a família e pelos interesses que geram o efeito de um "agrupamento por origem". Isto se revela nas táticas de reprodução no comércio, como o recrutamento de funcionários dentro da própria 
família ou, inicialmente, entre conterrâneos. Das dinâmicas de trabalho surgem determinados compromissos políticos e possibilidades de coalizão para a realização de interesses da colônia, além de outros interesses compartilhados com os locais atuantes no comércio. É esta articulação que pretendo chamar de "diaspórica" ou de "cosmopolitanismo diaspórico", pois revela relações que conectam pelo menos dois países, e pode traduzir uma mutualidade de perspectivas e interesses entre pessoas com ou sem background migrante no contexto urbano.

No próximo capítulo, a problemática da produção e da reprodução são tratadas com mais pormenores, a partir da rede que se evidencia com o recrutamento de parentes e de seus efeitos. Para tanto, concluo este capítulo com algumas considerações sobre "redes", e de como ela se apresentou como uma importante ferramenta analítica para a compreensão da atividade de mascate. "Mascatear" caracteriza o "início da vida em Manaus" para meus interlocutores, mas também é o paradigma da inserção dos migrantes árabes no Brasil para boa parte da literatura especializada. Além disso, destaco que a modelagem das redes sociais pode clarificar a compreensão em torno dos regimes de troca observados, pois, como destaco na próxima seção, o fundamento da noção de rede social é bastante próximo dos pressupostos da antropologia econômica, para a compreensão de que tipos de troca são determinados pelas normas produzidas nas relações entre as pessoas.

\subsection{Por quê mascatear? A família bilocal é uma rede com efeitos de reprodução do mascate e da colônia}

Haja vista que a presença de palestinos em Manaus teve como efeito a produção de outros palestinos, que também ocupavam a mesma atividade, considero que o processo de reprodução da atividade de mascate se deve à existência de vínculos com a "terra", explícitas especialmente no modo de recrutamento de funcionários. Além disso, considero que o motivo de formação da Sociedade Palestina explicita vínculos em outro nível, que podem ter se configurado como o primeiro conteúdo formal e amalgamador daqueles indivíduos. Não quero dizer que a relação entre estes indivíduos acontece apenas para estes fins, uma vez que são abundantes os casos de amizade e convivência entre os primeiros colonos, mas o intuito é o de destacar o princípio de uma fonte de subjetividade palestina, que está lado a lado com as dinâmicas familiares que se mantém bilocalmente. 
Assim sendo, neste último tópico proponho demonstrar como a noção de rede pode ser fonte para dar sentido ao processo de constituição da colônia pela conformação de uma modalidade comum de trabalho. Já que estes, os interlocutores representados aqui, cultivam relações fortes, regulares e intensas com a Palestina, a noção de rede vai ajudar a pensar sobre a persistência de tais relações e de como se constituem nas ações dos sujeitos. Quando digo "alimentar relações" quero me referir aos modos de manutenção de vínculos, seja investindo em propriedades na palestina, na manutenção das famílias, no recrutamento de funcionários dentro da própria parentela e na escolha matrimonial. Avalio que estas situações são os efeitos, e que as redes são os meios pelos quais acontecem e, portanto, dedico esta sessão à definição e à pertinência destes meios.

Existe uma diversidade de definições do termo redes sociais, e sua aplicação é bastante generalizada em várias áreas da produção científica. Apesar da naturalização do termo, o ponto comum é o de representar a situação estudada através de esquemas relacionados à imagem de malha, teia, constituídas por pontos ligados entre si, que indicam relações de várias ordens. A abordagem das redes sociais vai de uma análise propriamente qualitativa de descrição de grupos e associações, aos modelos quantitativos altamente técnicos derivados da teoria gráfica e álgebra matricial. As noções clássicas do termo remetem aos trabalhos de Barnes (1969) e Mitchell (1969), que apresentam respectivamente uma abordagem metafórica e analítica.

A abordagem metafórica estaria voltada à uma aproximação conceitual, enquanto que a abordagem analítica estaria centrada na metodologia de análise de redes. Importante notar que ambas estão intimamente ligadas a uma noção particular do objeto de análise (sociedade, cultura, grupo), definida em termos de estrutura ou sistema. Há ainda o que Acioli (2007) apresenta como uma abordagem tecnológica, o uso mais discutido atualmente, e cuja preocupação está voltada para as redes eletrônicas de conexões, que se colocam como mais uma das interações possíveis na sociedade. São, sobretudo, redes de informações e interorganizacionais.

Na sociologia, o uso analítico do termo é o que, ainda segundo a autora, têm sido o mais recorrente, especialmente na análise das redes de movimentos, redes de solidariedade, sobretudo para a compreensão dos processos de mobilização e formação de movimentos sociais. A análise das redes é, portanto, um modo de investigar as formas de interação e o sentido das ações coletivas e individuais. Mas na antropologia, foi apenas a partir dos anos 1960 que a ideia ganhou proeminência, pois, segundo Alvin Wolfe (1978) até esta década ninguém parecia entusiasmado com a ideia de uma analogia expressa entre sistema social e rede de relações sociais. 
Em "Redes sociais e processo político", Barnes se propõe entender a questão da política nacional através do deslocamento da análise das instituições para o que chama de matéria-prima da política, ou seja, as relações interpressoais. Segundo o autor, o comportamento político se vincula a ações dirigidas a outros objetivos não necessariamente políticos e que, portanto, não estão isolados em termos de espaço, tempo ou pessoa, mas que respondem, por exemplo, às expressões implícitas da política acadêmica, da política do esporte, da política da igreja, etc. Neste sentido, Barnes (1969) entende os processos políticos como transinstitucionais, como modo de apreender as relações estabelecidas sem correlatos de contextos rigidamente específicos.

Nesta percepção inscrevo a minha compreensão das relações percebidas em campo, entre palestinos e políticos e demais pessoas com influência nas tomadas de decisão política daquela cidade. Suponho que, também devido participarem dos interesses das camadas de média e alta renda das quais faziam parte, Farid e outros palestinos conviviam com a possibilidade de serem recrutados para a carreira política. O referido senador João Pedro mantém relações bem próximas com a família do Sr. Farid: "ele vivia na minha casa, cresceu junto com meus filhos". O próprio Farid revela já ter sido convidado para a carreira política. Além disso, pelo fato de serem antigos atuantes do comércio manauara, outros comprometimentos são reforçados e mais laços são criados. No entanto, nas minhas conversas estes interlocutores sempre entendiam ou queriam entender que meu objetivo era o de averiguar exclusivamente seus canais de articulação para o apoio ao povo palestino, e priorizavam estas descrições.

Os detalhes sobre as articulações comerciais são verbalizados por interlocutores como Farid e Omar para sinalizar que "fazem parte do Amazonas", ou que têm compromisso com os demais interesses locais e não apenas com o interesse do empresariado. Também traduzo esta retórica como uma tática para livrá-los da suspeita de que seus interesses são exclusivamente estrangeiros e incompatíveis com as necessidades locais. Nas retrospectivas de Farid e Omar, os palestinos são corresponsáveis pelo que chamam de "crescimento de Manaus".

Portanto, a ideia de que as relações são "redes" possibilita percorrer o caminho de muitas circulações, e entender que as relações interpessoais têm o potencial de gerar circuitos de saberes, bens, projetos e etc., não estruturados. A ideia de rede social exprimida por Barnes (1969) teve inicialmente a intenção de dimensionar os laços pessoais de parentesco e amizade em uma comunidade da Noruega. Seu esforço se segue uma vasta produção de pesquisas que se utilizaram do termo como uma ferramenta analítica no estudo 
de "processos políticos, classes sociais, relação entre um mercado e sua periferia, provisão de serviços e circulação de bens e informações em meio social não estruturado, manutenção de valores e normas pela fofoca, diferenças estruturais entre sociedades tribais, rurais e urbanas, e assim por diante" (BARNES, 1969, p. 173).

Trata-se de um conceito modalizador, um esforço de aproximação às relações sociais "efetivamente existentes", à realidade empírica em todas as suas particularidades relevantes, “a rede é uma abstração de primeiro grau da realidade e contém a maior parte possível da informação sobre a totalidade da vida social da comunidade à qual corresponde" (Barnes, 1969, p. 179). Este modelo extrai as implicações do fato empírico de que toda pessoa real impinge em outra ou entra em contato com várias outras pessoas.

$\mathrm{O}$ conceito se aplica tanto às relações positivas e diretas, quanto às relações não simétricas. A análise se dá a partir das relações diádicas que um ator possui nas redes das quais é membro, neste caso, uma rede "egocêntrica delimitada". Outra estratégia é a de se delimitar o conjunto de ação de um indivíduo, que diz respeito ao primeiro nível de relações do ego, e que também faz parte de uma complexidade e multiplicidade de relações, a partir da decomposição dessas relações e de uma análise das direções e dos tipos de fluxo de sequências-de-ação que perpassam os membros da sociedade.

De modo próximo, Boissevain (1974) aborda a constituição das redes sociais. Sua análise parte da compreensão dos indivíduos como empreendedores sociais, no processo de aquisição de capital social em alianças pessoais mutáveis. $\mathrm{O}$ autor atenta para a constante mudança das relações sociais que não podem ser descritas apenas em termos de norma. Em seu artigo, há uma preocupação com o lugar da escolha individual, ou dos comportamentos não estruturados, especialmente devido à compreensão de que não existem grupos corporados permanentes, mas coalizões temporárias ou ocasionais.

Em sua análise, as pessoas decidem seu modo de agir nem sempre baseadas nas normas de comportamento aceitas e sancionadas, o homem "está constantemente tentando melhorar ou manter sua posição, escolhendo entre os rumos alternativos de ação" (BOISSEVAIN, 1974, p. 211). Neste sentido, o homem extrai para si, das várias regras possíveis, o que lhe for mais conveniente para justificar a ação da qual é o principal beneficiado:

Estou sugerindo que as configurações sociais, tais como coalizões, grupos, instituições e sociedade, devem ser vistos como redes de escolhas pessoais competindo por recursos escassos e valiosos. Nem os indivíduos nem as configurações particulares que eles formam podem ser considerados separadamente (BOISSEVAIN, 1974, p. 215). 
Neste sentido, a participação de palestinos em várias coalizões não os desqualifica enquanto um "grupo palestino", uma vez que este último congrega e justifica a ação empreendedora da qual deve sua própria existência, uma vez que a Sociedade Palestina depende de recursos materiais para cumprir seus objetivos. A própria ideia de "colônia" se sedimenta numa retrospectiva de lutas e trabalho árduo, nos desafios da atividade de mascate e nos sucessos atribuídos tanto às qualidades individuais como ao cumprimento dos princípios religiosos comungados no grupo. Toda a coalizão para assuntos de interesse da colônia revela uma elaboração nos termos de ideais de trabalho e família, que, além de determinar finalidades específicas, geram efeitos de subjetivação e reconhecimento mútuo.

Wolfe (1978) afirma que o termo conquistou a simpatia dos antropólogos num contexto em que se fazia necessário à utilização de novos modelos apropriados para a compreensão dos complexos fenômenos sociais urbanos. Segundo o autor, as experiências dos antropólogos africanistas sugerem que o estudo da urbanização serviu como estímulo para o desenvolvimento da análise de redes. Nesta ocasião, conceitos como grupo tradicional, estrutura e instituição eram problematizados nas análises de Fortes (1949) e Gluckman (1940), principalmente nas situações que envolviam mudança e escolha, de onde decorre a importância da noção de rede, por evidenciar a expressão das relações pessoais no comportamento humano nas cidades e entre a cidade e o país.

A abordagem de rede foi precedida pelas tendências até então isoladas e que já compunham alguns estudos, como a tendência em enfatizar as "relações" ao invés das "coisas"; o interesse crescente na compreensão de "processos", ao invés das "formas"; a tendência em se priorizar a investigação de "fenômenos elementares", ou invés de “instituições"; e por fim, a tendência em se construir modelos geradores, ao invés de modelos funcionais (WOLFE, 1978, p. 56). A própria experiência etnográfica, segundo autor exige a investigação de todas as conexões possíveis, pois uma amostra representativa da situação social exige a observação de múltiplos conjuntos egocêntricos de relações com fronteiras nem sempre bem definidas.

A relação entre pessoas é, portanto, um fenômeno elementar, pois gera formas sociais que se regeneram e se adaptam de acordo com uma dinâmica própria, não sendo estruturalmente fixada. É preciso dizer ainda que esta abordagem também foi impulsionada pelos avanços da álgebra e mais tarde, pelo desenvolvimento da teoria de redes. Neste sentido, 
[...] network theory, when it develops, will generalize about relations among relations, how transactions affect such relations, how such relations affect transactions. But though they depend on transactions, these network statements will not be a kind of economics, for the relations at issue are not those between resources (e. g. "prices") but rather those between actors (true social relations) (WOLFE, 1978, p. 56).

Os trabalhos de Pasternak (1976) e Bott (1971) representam os exemplos clássicos do enquadramento etnográfico da análise das redes sociais. Segundo Robert Trotter (1999), a rede social etnográfica se configura como uma análise qualitativa e exaustiva no nível comunitário, na descrição de grupos familiares, redes de amizade, grupos de trabalho, associações voluntárias e outros tipos de grupos sociais. Outra abordagem que ganhou popularidade e que consta nos escritos de Barnes (1969) e Boissevain (1974) é a "egocentered" ou pesquisa de redes sociais ego-centradas. Esta última pretendia dimensionar as características psicológicas e sociais de modo contextual.

Ainda segundo o autor, a análise etnográfica tem priorizado a investigação comparativa das conexões entre diferentes grupos de pessoas, no sentido de dimensionar a força destes vínculos na determinação dos fluxos em jogo. Ou seja, a qualidade dos vínculos entre pessoas pode determinar deslocamentos e a reorganização das atividades e dos espaços em conexão. Os papéis que as pessoas desenvolvem e as posições que ocupam na rede afeta, por exemplo, o fluxo das informações (pessoas que estão em posições mais centrais tendem a controlar o fluxo informacional). Segue-se que a redução ou o baixo nível de centralização teria correlação com a possibilidade de mais determinação entre indivíduos não-centrais. Além dessas aplicações, Trotter (1999) aponta a elaboração de tipologias de rede e sua função interventiva em algumas situações.

Granovetter (1973) afirma que na maioria das análises sistêmicas, inclusive as supracitadas, o foco recai nos laços fortes, referentes às relações primárias ou formas elementares de inter-relação. $\mathrm{O}$ autor chama atenção para o que diz se tratar de uma falha grave da teoria sociológica de até então: o de relacionar interações de nível micro aos modelos de nível macro. Para o autor, estas pesquisas (BOTT 1957; MAYER 1961; MILGRAM 1967; BOISSEVAIN 1968; MITCHEL 1969...) não tratam as questões estruturais com o devido refinamento teórico.

A força de um vínculo é, como expõe, comumente associada a uma combinação do tempo, da intensidade emocional, da intimidade e dos serviços recíprocos que caracterizam a ligação. $\mathrm{O}$ autor tem implícitos em seu argumento pelo menos dois princípios: o de que quanto mais frequentemente as pessoas interagem mais forte será o vínculo entre elas; quanto mais fortes são os vínculos mais semelhantes serão as partes (indivíduos) que ligam. Um vínculo fraco é uma ponte, ou seja, as relações indiretas entre indivíduos, nas quais há sempre um ou mais indivíduos intermediários. 
Neste sentido, a ênfase nos vínculos fracos contém em si mesma a discussão das relações entre os grupos e a análise dos segmentos da estrutura social que não estão facilmente definidos nos termos dos grupos primários:

Intuitivamente hablando, esto significa que cualquier cosa que sea difundida puede llegar a un gran número de personas y atravesar una gran distancia social (como la distancia del recorrido) cuando se experimentan vínculos débiles antes que fuertes (GRANOVETTER, 1973, p. 6).

Vínculos fracos e fortes se constituem mutuamente, por oposição, e produzem coalizões definidas em função das transações que qualificam como includentes ou excludentes para a participação em determinada formação social.

No estudo das migrações, as redes sociais podem operar como mecanismos ligados a decisão de partir, bem como do modo de inserção nas relações no local de destino, na medida em que acontece pela ativação de contatos. Este esquema também pode possibilitar a visualização das formas de comunicação entre pessoas e grupos em situação de deslocamento, de trânsitos, que concorrem para a construção de virtualidades em "mundos imaginados", "ao permitir que as mais diversas experiências possam ser compartilhadas e que relações possam ser estabelecidas com uma velocidade de "renovação" e ressignificação cotidiana antes pouco provável” (BARRETO; DUTRA, 2012, p. 78).

O trabalho como mascate se deve, portanto, às relações que possibilitavam a inclusão no espaço demandado, que já começou desta forma por conta da inserção do primeiro imigrante de Beni Naim no esquema consolidado pelos patrícios. A abordagem de rede deve, neste sentido, considerar como as transações podem determinar relações e vice-versa, e no seu potencial de constituir formas sociais dinâmicas. É inegável que as relações entre conterrâneos palestinos em Manaus geraram um sentimento de grupo para atender questões mais amplas que as dos interesses individuais, e começou dependendo da ativação de contatos pessoais que remete ao primeiro emigrante de Beni Naim. As relações familiares ou de vizinhança em Beni Naim repercutiram na forma como estes sujeitos se organizavam para a conquista de um espaço no comércio de Manaus, que mais tarde elaborou a matéria-prima da formação societária na imigração.

A pesquisa de Silvia Portugal (2007) apresenta nítidos exemplos de como as redes determinam a dinâmica dos fluxos. Para a autora, existem determinadas normas sociais e princípios que orientam as ações neste âmbito e que no caso estudado apresentam bastante proeminência. Sua análise se detém nos laços de parentesco, que também apresentam elementos estruturadores das redes sociais totais. Silvia Portugal se preocupa basicamente com duas perguntas: que normas regulam as trocas no interior das redes? Laços diferentes obedecem a princípios diferentes? 
Os fluxos identificados no interior das redes caracterizam recursos diversos como emprego, habitação, saúde, bens materiais, são elementos materiais, afetivos e simbólicos a circular de acordo com os diferentes tipos de laços. A tese é a de que as normas no interior das redes refletem uma relação entre as pessoas, e não necessariamente um equilíbrio entre coisas trocadas. Isso porque Portugal (2007) interpreta a complexidade dos vínculos de parentesco a partir do predomínio do sistema da dádiva, que opera em princípios de equivalência, dependência, autonomia, liberdade e obrigação.

Os caminhos explicativos dos fluxos e dos laços identificados pela autora expõem a afinidade entre o princípio da antropologia econômica e o das redes sociais. O trabalho de Portugal (2007) permite pensar que os fundamentos da troca atendem às normas definidas pelas relações, no caso, às normas dos laços de parentesco. Uma vez que as relações podem ser pensadas enquanto redes, ou como uma malha de ligações entre pessoas comprometidas entre si para algumas situações e em alguns graus, os elementos materiais, afetivos e simbólicos transacionados no interior de uma rede respeita à lógica de sua produção enquanto um conjunto de relações dotadas de um senso normativo. Este senso normativo não é um sistema rígido e autorregulado, mas relativamente autônomo pois apresenta elementos estruturadores das redes sociais totais.

Neste sentido, a circulação da dádiva no tipo de rede parcial estudado por Portugal (2007) depende do caráter dos vínculos e engendra uma assimetria de posições entre os atores envolvidos, e acaba por ser indeterminada, uma vez que constrói uma relação em que os envolvidos nunca são apenas doadores ou receptores. A autora recorre ao conceito de dívida utilizado por Godbout (2000), por entender que se revela mais produtivo do que a ideia de reciprocidade para analisar a circulação da dádiva neste nível, uma vez que filhos, pais e avós fazem parte de uma cadeia intergeracional em que pese a noção de um tempo diferente.

Desta perspectiva, tudo pode ser transacionado, a depender do tipo de laço correspondente. Portugal (2007) inclui uma dimensão importante nesta problemática, a de que as redes devem representar também as assimetrias envolvidas, pois além da proximidade ou distância entre as partes, as diferenças entre as pessoas determinam os fluxos de suas relações. Como exponho no capítulo seguinte, a atividade comercial se constrói a partir do domínio de certos saberes e práticas e que, portanto, dependem da socialização do sujeito neste ambiente. Uma vez que a possibilidade de trabalhar no comércio em Manaus depende da convocação por um parente já estabelecido, a situação de 
quem oferece a oportunidade e a de quem recebe apresenta as características da dívida. Neste sentido, as relações fortes podem ser produzidas pela noção da dívida nos mecanismos de convocação e apoio comercial, da qual se seguem expectativas em termos de contra-prestações que, por consequência, geram relações mais duráveis.

Para Frykman (2004), as ações, as decisões e as identidades também são negociadas a partir de redes de relações, que podem conectar simultaneamente dois ou mais estados-nação. Deste modo, o imigrante (como uma categoria de pesquisa), pode ser conceituado como vivendo em contextos transnacionais. A partir de pressupostos semelhantes, Feldman-Bianco (1999) articula o padrão da família extensa portuguesa com a intensificação das estruturas familiares transnacionais, através das quais as decisões da vida cotidiana das famílias que vivem entre Portugal e Estados Unidos são tomadas. Esta situação também promove uma intensa circulação de bens e pessoas, com efeitos de transnacionalização do consumo e da economia doméstica.

A prática de enviar dinheiro, construir casas na palestina e providenciar o casamento dos filhos, não por acaso, garante a reprodução de suas famílias em Beni Naim. Naquele local, meus interlocutores reconhecem um ambiente propício para a preservação do que descrevem como a "mentalidade palestina". É assim que as possibilidades de reprodução no comércio são produzidas, pois dos parentes palestinos recrutados se espera um comportamento específico com relação aos acordos e às condições de trabalho. A família que se estende entre as duas localidades também possibilita efetivar os ideais de "família árabe", por razões que serão detalhadas no último capítulo. As decisões com relação ao comércio e à família são tomadas levando em consideração as relações disponíveis. As decisões de ir e vir, de dar uma loja ou uma esposa, são agenciadas dentro de uma perspectiva de preservação, tanto do patrimônio como da família.

Como se vê, a noção de rede permite a identificação dos mais variados fluxos constituintes na vida dos sujeitos. Os fluxos de informação, de pessoas, de objetos e etc., contribuem nas suas ações independentemente das situações imediatas ou do espaço físico imediato no qual se encontram. De posse desta ferramenta analítica, considero que existem fluxos cujo lugar originário não é Manaus, e que definem as ações e expectativas dos sujeitos incluídos nesta pesquisa. Assim é podemos dar sentido à "palestinidade" evocada por estas pessoas, e criada na situação de deslocamento. Da mesma forma se configuram os casamentos, as famílias e os negócios, por meios que julgam fazer parte de outro registro de significados, um registro transnacional. 


\section{CAPÍTULO 2 - NO MERCADO}

Na primeira parte deste capítulo faço uma discussão teórica a respeito dos sentidos do dinheiro. Este movimento torna-se necessário porque o dinheiro é o veículo pelo qual se fixam os acordos entre parentes ou conterrâneos, nos quais também estão implicadas noções de dívida. Ao atender à convocação para trabalhar em Manaus, dívidas são contraídas e expectativas são criadas em torno dessa relação. Percebo que o dinheiro pode ser a pista para entender como as relações comerciais podem adquirir o sentido subjetivo das relações entre parentes, e que não pode ter sua racionalidade produzida apenas na perspectiva do cálculo ou do maior lucro. A constituição de suas empresas é uma prova de que outra lógica concorre com a lógica da eficiência impessoal, pois os parentes recrutados para assumir postos importantes não costumam ter qualificação profissional.

A seguir, descrevo como se dão as trocas no âmbito comercial, privilegiando as relações que promovem o deslocamento de homens para Manaus e as implicações constituintes desse processo. Articulo o processo de "inserção" dos migrantes com os circuitos do comércio varejista, e destaco o papel da transmissão do dinheiro na produção de relações duráveis entre as partes contratuais. A argumentação culmina na demonstração de como as práticas comerciais, inclusive aquelas informadas pela concorrência de mercado, atendem a relações de reciprocidade e contribuem para a sustentação de uma "colônia palestina" baseada em princípios de solidariedade étnica e moral religiosa.

A geografia comercial associada aos principais interlocutores desta dissertação sugere um imbricado de redes de circulação de produtos e pessoas. O cenário é de intenso movimento nas ruas estreitas e superpovoadas por ambulantes, pedintes, compradores e vendedores com os mais variados interesses e táticas apelativas de distribuição de mercadorias. Ali também é o lugar do "baixo meretrício", dos comportamentos "pervertidos", e do desembarque da população do "interior". Das embarcações tradicionais, que conectam a "cidade" ao "interior" predominantemente "ribeirinho", descem os amazonenses "típicos", que usufruem de regular circulação no meio urbano.

O "comércio" de Manaus é o espaço que melhor concentra os produtos para as diversas necessidades, sobretudo para quem procura preços baixos. É um espaço marcadamente popular, distinto por um desenvolvimento comercial desordenado que reflete, palidamente, o auge da convulsão comercial vivida entre os anos 70 e 80 . Neste 
contexto, a territorialidade é definida por estratégias de vinculação e articulação em redes. Considero também que os interlocutores apresentados aqui compõem uma formação social marcada por processos de circulação translocais de pessoas, de commodities, crédito, informação ou dinheiro.

A cidade de Manaus, como um espaço da experiência interétnica de migrantes, revela tanto situações de compartilhamento de significados como manobras estratégicas e criativas por parte dos indivíduos para a integração em circuitos e redes. Essa integração é possível na medida da manutenção ou do estabelecimento de novos vínculos, que muitas vezes transpõem territórios espaciais e simbólicos. É a partir deste cenário analítico que busco construir os dados sobre as táticas de reprodução social de uma classe do empresariado manauara, a dos Palestinos.

Assim, pretendo explicitar certas dinâmicas de reprodução pertinentes a alguns casos verificados na "colônia", que inclui parte dos homens abastados e de famílias modestas, as quais obtive acesso principalmente através das mulheres e jovens. Não suponho que a ideia de "empresários palestinos" funcione como algum tipo de enclave étnico, mas sugerir que as suas características e de suas famílias se configuram a partir da complementaridade do que defino como "ações comerciais" e "domésticas" muito próprias a este coletivo, constituídas por meio de diferentes modalidades de troca.

Para dar sequência ao meu argumento, devo lembrar que chamo de "ações comerciais" aquelas que acontecem no âmbito do mercado, e de "ações domésticas", as que acontecem no âmbito da casa. A distinção entre "casa" e "mercado" originalmente formulada por Gregory (1997), que as associa a formas distintas de valoração sobre coisas, pessoas e relações. Uso esta distinção para marcar como as ações comerciais podem corresponder a uma lógica de "casa", quando passa a assumir características de uma ação doméstica, só que realizada no âmbito do mercado.

\subsection{Nas pistas do dinheiro}

Mauss (1924) inicia o capítulo que versa sobre os sistemas de prestações econômicas do tipo "dádiva" com a seguinte pergunta: que força existe por trás da necessidade de se retribuir? Mais tarde, David Graeber (2011) também constrói interrogação semelhante a respeito das dívidas monetárias entre os países. Enquanto Marcel Mauss centra no objeto e na sua relação 
com o primeiro dono, nas noções êmicas sobre o caráter "sagrado" do objeto transacionado que reside, por exemplo, no fato de conservar algo do seu doador, David Graber não contempla a coisa como importante em si mesma, mas na relação que estabelece entre duas pessoas.

Embora optem por caminhos retóricos distintos, ambos concordam em explicar a obrigação de retribuição a partir de razões morais ou religiosas. Para Graeber (2011), as dívidas sempre existiram, mas nem sempre houve a necessidade de serem pagas. As dívidas assumidas na forma atual enquanto dívidas em dinheiro expressam apenas a evidência de que, ao inverso do que os economistas clássicos propõem, os sistemas de créditos precedem em muitas décadas o aparecimento do dinheiro. $\mathrm{Na}$ argumentação que se opõe à compreensão liberal de que o dinheiro foi inventado para viabilizar trocas, o dinheiro é entendido como o atestado de uma "dívida", o primeiro interesse das trocas.

Marcel Mauss elaborou e sintetizou princípios explicativos paradigmáticos para a discussão de sistemas econômicos na antropologia. O primeiro princípio é o de não tentar tratar a economia como uma lógica autônoma, em que a razão econômica seja independente de qualquer outra esfera da sociedade. E disto decorre outra assertiva fundamental: a de não criar qualquer separação radical entre sociedades ditas da "dádiva" e sociedades com sistemas de mercado. Para ele, a necessidade de retribuir, característica das sociedades da "dádiva", está em todo lugar, e é precisamente isto o que constitui a base da sociedade, dado que as obrigações do dar e do receber fundamentam o sistema de alianças que é o princípio amalgamador de qualquer sociedade.

Nos exemplos discutidos em "O Ensaio sobre a dádiva", as coisas são dependentes das relações entre as pessoas, de modo que o objeto transacionado simboliza ou sintetiza a relação na qual se desloca. Nas sociedades em que predominam sistemas de mercado capitalistas, a relação principal já não é entre pessoas, mas da sua relação com uma coisa (advento da propriedade). Nestes sistemas as pessoas passam a se relacionar entre elas em função das coisas, que podem adquirir importância em si mesmas, diferentemente das sociedades tipicamente "tribais" em que o valor é prescrito pelo que representa na relação que estabelece. O dinheiro, nas sociedades capitalistas, tende, portanto, a assumir um caráter impessoal, separados de toda relação com pessoas morais, coletivas ou individuais que não sejam a autoridade do Estado que se impõe (MAUSS, Cap. 2, nota de rodapé 29).

Mas, como continua o autor, este é apenas um caráter da moeda, aquele que assume na maioria das sociedades ocidentais, pois outras moedas possuem natureza mágica, além da natureza econômica, e estão ligadas a seres morais que individual ou coletivamente estabelecem 
algum contrato. Na sua definição, tais moedas são instáveis, pois não representam um valor fixo ou padronizado, apesar de também poderem representar valores em si. O autor esboça uma possível história para o advento da moeda tal como a concebemos hoje: primeiramente, apesar de mágicas, as coisas às quais se atribuíam valor também foram percebidas como podendo ser alienadas das relações. Após fazer estas coisas circularem na tribo, a humanidade descobriu que elas poderiam servir como meio de contagem e circulação das riquezas. Foi assim que, posteriormente, se inventou um meio de separar as coisas preciosas dos grupos e das pessoas, para concebê-las como instrumentos permanentes de medida de valor.

Para Mauss (1924), dinheiro e mercado eram "human universals" cuja principal função foi a extensão da sociedade pra além da esfera local. Neste sentido, até o kula pode ser considerado um movimento econômico de baixo ("from below"): "we offer gifts on first dates or in diplomatic missions to foreign powers. How do we push the limits of society outward? For him money and markets were intrinsic to this process" (HART, 2005a, p. 93). Dinheiro e mercado têm, portanto, as suas origens no esforço de se estender a sociedade para além de seu lugar original. O dinheiro possibilita trocas com qualquer pessoa ou grupo ou sociedade do mundo, uma vez que todo dinheiro moderno é aceito por todo mundo.

Mauss (1924) não desenvolve as implicações das diferentes "funções" pelas quais a moeda passou até adquirir a condição para ser trocada por qualquer coisa, e ser reconhecida por todos os partícipes do contexto em que circula. Entretanto, uma gama de antropólogos preferem evitar atribuir um potencial revolucionário ao dinheiro ocidental moderno, recusando tomá-lo como indicador necessário de "modernidade" ou de transformador radical de sociedades com outras economias. Autores como Polanyi (1968), Gregory (1997), Keith Hart (1986; 2005a; 2005b), Parry e Bloch (1989) e Guyer (1995 a; 1995b), compartilham o pressuposto de que a possibilidade de haver coexistência entre dádivas e trocas mercantis no sentido empregado por Mauss (1924) está na própria moeda, entendida no seu potencial de assumir características pessoais e impessoais concomitantemente. Trata-se de uma evidência etnográfica muito comum, uma vez que a compreensão ocidental e moderna de sistemas de troca é que construiu a separação rígida dos domínios da "dádiva" e do "mercado".

A argumentação sustentada por estes autores evidencia que tais domínios estão muito borrados numa realidade que se apresenta muito mais complexa, mais próxima, portanto, da conceituação de Gregory (1982), em que "gift" e "commodity exchange" são: "the first is based on an exchange of inalienable objects between interdependent transactors; the second an exchange of alienable objects between independent transactors" (PARRY; BLOCH apud 
GREGORY, p. 8). Entendidas dessa maneira, as práticas associadas às ideologias de "sociedades da dádiva", podem não apenas integrar intercâmbios de objetos alienáveis como também não apresentar uma forma pura da "dádiva", além de empregar ao dinheiro diferentes sentidos a partir do uso em diferentes contextos de uma mesma cultura.

A ideia geral da qual se desenvolvem as subsequentes teorizações acerca da economia é de que está embutida (embedded) na sociedade e que, portanto, nenhum objeto é dinheiro per se, de modo que qualquer coisa pode funcionar como dinheiro. Polanyi (1968) indica quatro usos para o que se têm considerado como "dinheiro". O primeiro é como meio para efetuar pagamentos e neste sentido, há vários testemunhos etnográficos, como o caso estudado por Mary Douglas (1958) sobre a circulação de um tipo de tecido, o raphia cloth, no grupo pesquisado. Trata-se de um caso emblemático da circunscrição de um grupo a partir de um sistema de pagamentos efetuado exclusivamente com raphia cloth. Neste caso, o raffia só pode ser adquirido dentro de um sistema de relações e obrigações e mediante certas ocasiões em que nunca pode haver substituição por qualquer outro "dinheiro".

O segundo uso para o "dinheiro" envolve uma noção que o atribui de valor; são bens preciosos passíveis de acumulação com vistas ao entesouramento pelo valor que representam em si. O outro uso do "dinheiro" exige o cálculo de sua equivalência, mesmo que abstrato, com a finalidade de equacionar as coisas trocadas por meio dele. Este sentido exige a noção de um valor padrão, um consenso sobre as condições de troca direta. E, por fim, existe um último uso do "dinheiro", aquele que adquire a função da "moeda". Este é o uso de objetos quantificáveis com vistas a adquirir objetos com a mesma equivalência em termos abstratos. Não se trata de uma troca direta, mas de um recurso que me permite trocar coisas que não tem equivalência entre si, por meio de um valor comum quantificado em "moeda", que pode ser qualquer objeto.

Neste último aspecto, o dinheiro adquire um valor comunicacional entre diferentes pessoas, de diferentes países e continentes, pois assume um valor padrão intercambiável em uma escala muito maior, invadindo sistemas regidos por moralidades opostas às do uso impessoal. Gregory (1997) apresenta uma contribuição notável para as discussões acerca das trocas econômicas proeminentes no cenário antropológico de então, cujo interesse passava primeiramente pela definição antecipada do dinheiro. O autor desafia a necessidade essa disciplinar dominante que impossibilitava a aferição da multiplicidade de valores e sentidos evocados pelo dinheiro. Em ruptura com o modelo estrutural de esferas de troca construído por Bohannan, Gregory opta pela assunção da coexistência entre sistemas de 
valor dos tipos commodities e gift, de modo que "dinheiro/moeda" poderia assumir qualquer uma dessas qualidades em circunstâncias de reconhecimentos recíprocos dentro de um mesmo coletivo.

A proposta considera a primazia do "livre mercado anárquico" como um valor global, mas não universal, de modo a enfatizar a percepção de valores contraditórios, cognições rivais e suas configurações nas relações humanas. Sendo assim, a atenção do autor se volta para as formas de consciência na produção de valores sobre coisas, pessoas e relações, definidos basicamente a partir das dimensões do mercado e da casa (Market e House). O autor se define como um humanista radical, na medida em que "symbolists focus on marks and their meanings, institutionalists on the formal process of valuation, materialists on the ecology and technology of production, and radical humanists on the relations of reciprocal recognition between the valuers" (GREGORY, 1997, p. 15).

O mais básico do reconhecimento recíproco é aquele que define relações de consanguinidade, afinidade e contiguidade, a partir dos quais se constroem valores e seus critérios pertinentes à dimensão "doméstica". Ao considerar o sistema de parentesco, o autor não parte da lógica das estruturas, mas das políticas de relações de valor nas interações entre as pessoas com quem se relacionava em campo. Neste sentido, temos a percepção de que, não obstante apresentar-se na forma aceita globalmente, o dinheiro pode adquirir um valor subjetivo e pessoal, na medida em que os contratos entre seres morais e corporados lhe façam uso.

Jane Guyer (2005b) oferece um exemplo curioso do uso do dinheiro ocidental moderno no sistema de atribuição de valores africanos. No contexto considerado, a autora revela que os africanos, acostumados a poupar, estocar e acumular bens de valores estáveis, tiveram seu sistema afetado pelo sistema econômico colonizador. Os dinheiros correntes foram "substituídos" pelo dinheiro europeu, mas com sentidos muito particulares. A instabilidade decorrente da incorporação de um novo sistema econômico foi apreendida como mais uma das sucessivas instabilidades dos dinheiros em uso, pois não haviam estados centralizadores de uma circulação monetária, ou seja, a população lidava comumente com várias moedas, pois a consciência do risco em se confiar em apenas uma já era incorporado.

A autora evidencia que as relações interpessoais deste contexto estão permeadas por regimes de trocas, em dinâmicas muito complexas definidas em face da herança pré-colonial e das transformações do período colonial. Neste sentido, qualquer análise que pretenda compreender os sistemas de troca deve lidar também com a constante mudança dos “dinheiros" que circulam, e nas estratégias de poupanças de valores que não passam 
necessariamente na acumulação de moedas, mas no investimento em relações por exemplo. Para a autora, é imprescindível considerar os mecanismos de preservação do valor dos bens ou objetos preciosos, como sugere o investimento do dinheiro europeu em assets, como a terra. Isto está estreitamente ligado à compreensão do "dinheiro" na sua expressão como crédito, uma vez que funciona como sustentação do valor.

A consideração sobre a produção de valor no contexto africano tem no conceito de wealth in people uma famosa síntese descritiva, elaborada por Miers e Kopytoff, como esforço para compreender os princípios da vida social africana, baseados na acumulação de relações sociais e na proeminência do parentesco. Isto porque nas análises clássicas, como expõe Guyer (2005a), subjazem preocupações sobre "the cultural creation of persons, the meaning of transactability, and the possible relationship between persons and things, in general and in highly specific situations or transactions (Guyer, 2005a, p. 86). A autora adverte que considerações a respeito desses sistemas devem ser muito delicadas, uma vez que a própria ideia de valor é declinada em diferentes sentidos, de modo que as ideias implícitas nos modelos compreensivos clássicos, como a de "coisificação" e "pessoalidade", são desafiadas constantemente.

A atribuição de valor na relação interpessoal possibilita a preservação da mesma, mas pode representar, em outros termos, um investimento que intenta produzir relações duráveis, que, sendo moralmente prescrito, pode constituir o princípio de construção de socialidades, como as implicações da "dádiva" já indicavam. Este aspecto evoca uma importante tensão entre a moralidade prescrita como ideal societário com suas estruturas simbólicas, e o aspecto individual das condutas demandadas em ambientes de intensa competição individual como o comércio, por exemplo. Trata-se de uma dimensão que envolve fatos e normas como expressões de uma unidade dialética mediada pelos valores em jogo (GREGORY, 1997).

Os autores Parry e Bloch (1989) propõem um redirecionamento da análise de processos transformativos que sai da consideração dos sentidos do dinheiro para uma percepção dos sentidos dos sistemas de transação como um todo, que permite corporificar esta tensão de uma maneira singular. A proposta destes autores se assemelha à distinção de Gregory (1997) entre políticas de produção de valor nas dimensões da "Casa" e do "Mercado", com a diferença de que aqui a ênfase recai nos efeitos das ordens transacionais verificadas nas etnografias que a obra reúne, que identificam uma ordem ligada à reprodução social a longo-termo e uma ordem de transações de curto-termo, referentes à arena da conduta individualista. 
A ordem transacional de longo-termo se refere à reprodução nos termos das prescrições e normas moralmente aceitáveis para a manutenção da organização social, são ciclos restaurativos de uma ordem cosmológica por exemplo. A ordem transacional de curto-termo não compete ou exclui a ordem anterior, mas é subordinada e seus espaços de condutas individualistas, como as demandadas pelo comércio, são integrados. É uma ordem moralmente aceitável na medida em que não interfere na reprodução dos ciclos de longo-termo, podendo contribuir nestes ciclos, de modo que o emprego do dinheiro resultante das trocas de curto-termo, pode, por exemplo, ter seu sentido simbolicamente transformado pela sua aplicação em recursos benéficos na sustentação de uma ordem comunitária (PARRY; BLOCH, 1989).

Gregory (1997) identifica este processo como sendo de "domesticação", em que objetos ou relações de uma ordem transacional exógena passam a ser integrados em uma lógica endógena e vice-versa. Nos casos de comunicação entre diferentes lógicas transacionais, ocorre o que o autor chama de um "reconhecimento assimétrico" dos sentidos da transação. Dentro de uma mesma lógica, o mútuo interesse pela manutenção de um reconhecimento recíproco entre as pessoas, suas bases e normas de reciprocidade, contribuem para a perpetuação do sentido que tem por efeito a reprodução.

Transpondo a proposta analítica que atenta para as políticas de valor que tem por efeito a reprodução social em dinâmicas integradas de curto e longo prazo, sugiro que as práticas dos sujeitos representados aqui podem ser assim entendidas porque eles vivem uma experiência de "sociedade" ou "colônia". Sendo assim, não pretendo atribuir as práticas verificadas aqui ao fato de serem conterrâneos, mas sim à organização em "colônia", que representa a virtualidade de esquemas de reciprocidade com efeitos de reprodução. Sendo assim, o que é obtido no espaço da competitividade e proeminência individual, atende também às responsabilidades pertinentes ao âmbito da "casa", na acepção de Gregory (1997), mas também da "irmandade", sendo convertido pelo investimento em relações, a partir do binômio crédito/dívida, e sendo purificado pela conversão em usos nobres.

O termo "purificação" é bastante representativo destes processos, possuindo considerável peso para explicações de situações onde há separação ou imposição de fronteiras ontológicas e limites de poder exclusivos. Para o meu argumento, a potência deste termo se faz sentir nos processos em que o dinheiro é transformado em dádiva, o que implica dizer que ele passa de um domínio para outro, ou de um regime de troca para outro. A concepção da existência de diferentes regimes de troca típico-ideais pressupõe um processo de separação, de configurações excludentes de produção de sentido. Como aponta Silva (2015a), é a fonte de 
produção da diferença que cria possibilidades de purificação, ou, transpondo para o vocabulário desta dissertação, são as convicções sobre o que deve ser trocado e com que pessoas que institui as diferenças de regime. Portanto, a "purificação" neste caso fala da possibilidade de transformação do elemento adquirido no regime de mercado para o da ordem transacional de longo-prazo.

São, portanto, nestas implicações que proponho pensar as relações verificadas a partir dos sistemas de empréstimos entre homens palestinos em Manaus. Sobre o delicado e mudo princípio de retribuir à altura do que foi recebido, como sendo estruturado pelo mesmo princípio que reúne as relações entre os demais membros da colônia, princípios que prescrevem cordialidades, retribuições e distribuições. Passo agora à demonstração de como a atividade comercial revela critérios de confiança, competição e expectativas de reciprocidade, evidenciando como o espaço da "casa" tem importante relação com o do "mercado".

\subsection{Reciprocidade e negócios}

Tendo conseguido se fixar em uma loja própria, estes primeiros imigrantes passaram a trazer os parentes que definem como sendo os mais próximos: irmãos e sobrinhos, para trabalharem junto de si. Os que vieram há mais tempo conseguiram garantir imóveis que hoje são praticamente impossíveis de adquirir, de modo a criar uma nítida diferença no resultado do projeto imigratório entre diferentes gerações. Se a parentela a quem recorre em Manaus goza, já no momento de chegada do novo migrante, de estabilidade e bons lucros, certamente seus pupilos terão boas chances de conseguir progressão financeira.

"Ele nasceu com o bumbum virado pra lua e com uma colher de ouro na boca", foi o que ouvi do Sr. Fauzi quando inquirido sobre as diferenças entre os resultados dos projetos migratórios dos palestinos que conheci; eu me referia a Omar que vive uma expansão notável nos negócios. Em tese, os imigrantes palestinos de segunda geração deveriam ter tido possibilidades muito semelhantes no processo de acumulação de bens. Mas Sr. Fauzi revela que Omar gozava de condição invejável, pois recebeu ajuda do sogro, Osmar, que detém muitos bens. Importante destacar que Omar não revelou com clareza os nomes das pessoas ou os tipos de ajuda que recebeu quando chegou, na sua versão, ele destaca as qualidades pessoais que o fizeram ter sucesso, e não as ajudas com que contou. Já Fauzi, não hesita em contar que isso se deve ao apoio recebido do sogro milionário. 
Duas questões surgem destas retóricas e que pretendo desenvolver nesta seção. Em primeiro lugar, estar na condição de "ajudado" não é motivo de orgulho, pois parece acusar uma situação passiva, de alguém ou de uma fortuna que dependeu do trabalho de outrem e que portanto, não deve ser dita, ou pelo menos não desta forma. Em segundo lugar, a explicitação da variável "ajuda" nesses casos pode advir de pessoas interessadas em disputar a genuinidade da fortuna, que tem maior valor quando conseguida pelas próprias mãos. Mesmo não tendo o mesmo sucesso de Omar, Fauzi não se deixa vencer, e aciona outras condições para que a trajetória seja reconhecida como de sucesso, condições estas verbalizadas pelo próprio Omar. As disputas em torno da "ajuda" também se caracterizam como uma das fontes de competitividade, que será desenvolvida na próxima seção deste capítulo.

Além de a retrospecção sobre a trajetória ser elaborada em termos de exaltação do trabalho em condições que serão expostas mais adiante, a "ajuda" implica numa relação de dádiva, que possui como característica a personalização dos recursos doados aos quais se atribui grande força ou efeito moral. Neste sentido, a "ajuda" é um grande penhor moral que coloca os receptores em situação de subserviência. Portanto, as declarações sobre as transações de bens entre parentes são difíceis, até porque são evitadas, o que corresponde a uma nítida diferença das relações com os locais e entre palestinos ou parentes, associadas aos diferentes tipos de regime de troca vigente em cada relação. Pretendo expor tais diferenças para demonstrar como as relações na colônia são permeadas pela economia da dádiva, bem exemplificada no processo de "puxar" parentes.

O processo de "puxar" parentes, expressão utilizada para dar sentido à convocação de parentes em Beni Naim para Manaus, ocorre com alguns critérios. Com exceção das primeiras migrações, os palestinos que deram continuidade ao deslocamento eram irmãos ou sobrinhos dos que já estavam aqui. Na medida em que foram casando e constituindo a própria prole, e também pelo aumento dos lucros que proporcionou a expansão do próprio comércio em redes de lojas, esta "ajuda" passou a atender critérios de parentesco consanguíneo ou por afinidades específicas, dentro de uma lógica própria. A seguir, represento as ligações entre parte dos interlocutores masculinos da pesquisa: 
Figura 4 - Representação hierárquica do sistema de "ajuda".

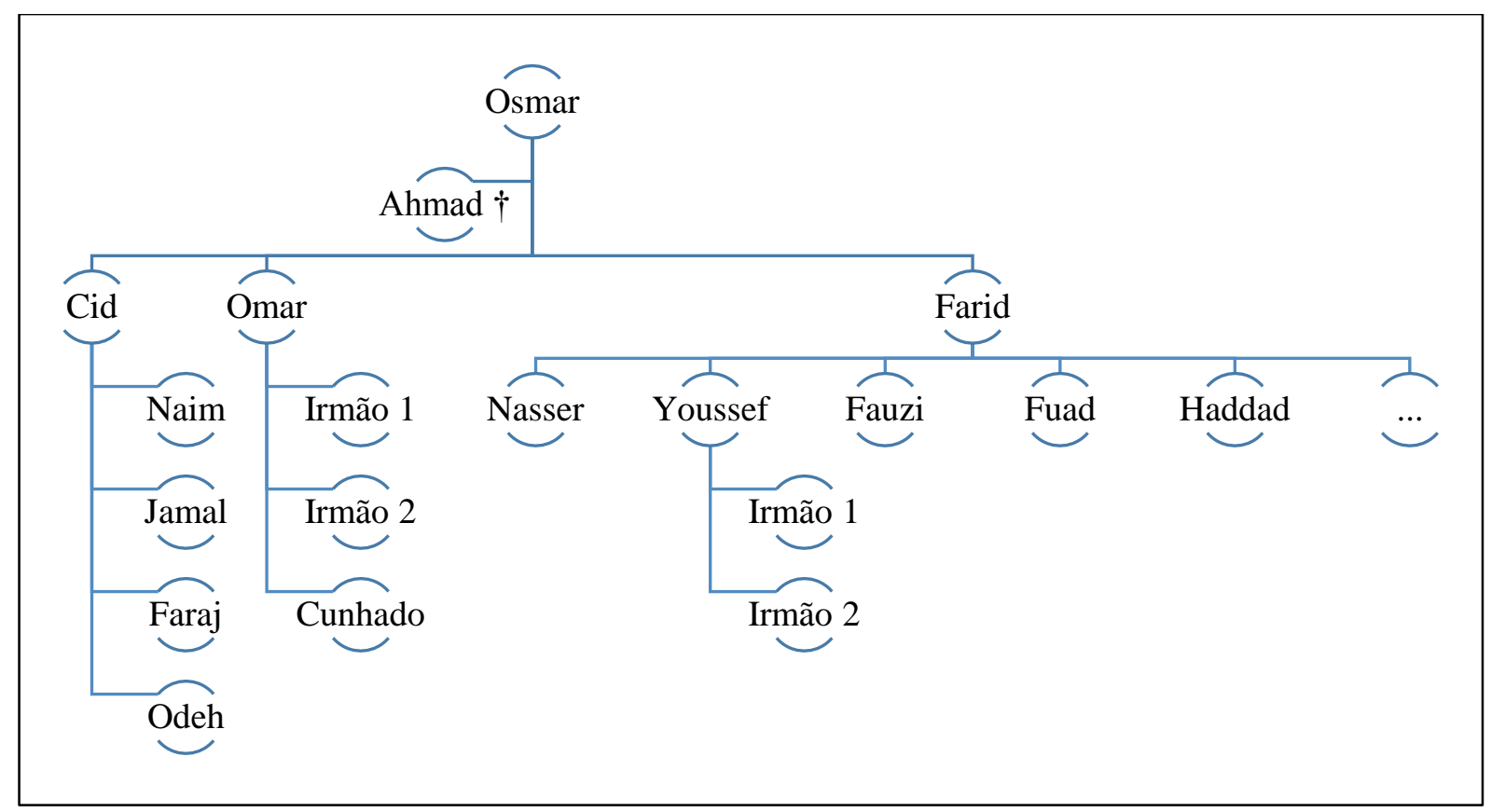

As posições relacionalmente superiores indicam "transferência de ajuda", enquanto que as relacionalmente inferiores indicam "recebimento". A convocação de alguém para trabalhar consigo depende da necessidade dos negócios, e não do fato de estar desempregado ou ganhando pouco dinheiro na Palestina. Ainda que isso seja uma condição para quem está na Palestina aceitar o convite para migrar, muitos irmãos dos que em Manaus são donos de importantes lojas continuam trabalhando na agricultura ou em pequenos comércios em Beni Naim.

O início dos trabalhos junto aos parentes para um recém-chegado da Palestina é comunicado como tendo sido de muito trabalho. Nas décadas de 70 e 80 , a segunda geração encontrou a parentela com um negócio próprio, pelo menos uma loja de confecções, que empregava os seus pupilos em alguma modalidade de venda. Um interlocutor de aproximadamente 70 anos, que chamarei de Nasser, expôs a sua impressão de como se dá a progressão de um recém-chegado:

Quando o irmão ou o sobrinho vem trabalhar eles trabalham de boca fechada, até que quem o trouxe diz 'chega!', e dá uma loja pra ele tomar conta, e diz 'agora você me paga essa loja, e o que tem aí dentro', e essa pessoa terá que fazer qualquer favor para aquele que o ajudou. Eu, quem me ajudou foi o Farid, eu devo a ele pelo resto da vida. 
Como bem exemplifica o discurso supracitado, a problemática das trocas é uma poderosa janela epistemológica para entender parte da dinâmica de reprodução social da elite da colônia palestina em Manaus. As pessoas constituintes da "colônia palestina" estão ligadas por certas dependências que criam relações muitas vezes tensas, a promoverem proximidades vigorosas ainda que por interesses nem sempre afetuosos. Neste sentido, considero que tais dependências indicam obrigações morais de longo prazo, que tem por efeito um sentimento de coesão pelo reconhecimento recíproco dos sentidos das "ajudas".

A relação entre irmãos, pai e filho ou tio e sobrinho sócios em uma rede de lojas, está sujeita a situações de conflitos pelas dívidas ou créditos criados nas transações comerciais. Ao aceder ao chamado para trabalhar junto a um parente, o pequeno produtor palestino está contraindo dívidas. Ele é "ajudado" financeiramente, recebe abrigo na casa do tio ou irmão, se alimenta, dorme, recebe atenção e cuidado, além de tomar conhecimento de todo o minucioso esquema das relações comerciais que deve aprender com o máximo de aproveitamento para conseguir "tocar seu próprio barco".

As "ajudas" no âmbito comercial são o mecanismo por excelência de produção de relações duráveis entre quem ajuda e quem é ajudado. São dívidas contraídas e que pedem um retorno equivalente. Embora alguns garantissem a despretensão daquele que ajuda, em algumas conversas obtive exatamente o inverso quanto a esse tipo de transação. Como protestou Youssef, se trata de um empréstimo:

Dinheiro dado ninguém dá! No começo se dava mercadoria e a ajuda do
conhecimento, apresentar aos fornecedores para 'avaliar', como 'avalistas
moralmente'. E no começo todos moravam próximos, mas depois, é cada um por si.

A viabilização dos acordos com os fornecedores de mercadorias é crucial nesse processo. Isso acontece porque, em geral, as compras para abastecer as lojas de confecção alcançam valores que requerem uma garantia, no caso, de um "avalista moral" que certifique a credibilidade do sujeito interessado no produto. A transferência de saberes neste setor é crucial para o conhecimento dos principais fornecedores para as mercadorias em alta no ramo, bem como de outras informações igualmente essenciais. Os parentes mais antigos são quem detém tais saberes, podendo indicar os caminhos que os levam às aquisições adequadas para um mercado muito volúvel, em que a informação é extremamente valorizada.

Neste aspecto, ocorre uma aproximação bastante pertinente com o que Clifford Geertz (1978) cunhou de "economia de bazar", no seu estudo sobre o bazar marroquino, que considera como sendo uma instituição cultural fundamental do Oriente Médio. Nestes espaços, a 
manipulação da informação "costura as relações sociais no seu interior, estabelecendo, por exemplo, graus de hierarquia, mapeando campos de disputa e redes de solidariedade, situando quem é quem no espaço do mercado, estimulando usos de retóricas eficientes nos processos de negociação sobretudo nos desempenhos de barganhas, etc.” (MELLO, s.d, p. 6). Neste contexto, os problemas do acesso à informação caracterizam os processos de circulação e intercâmbio de modo a dificultar a obtenção pelos atores de informação confiável sobre as pessoas ou as coisas.

\subsection{A disposição competitiva}

As rivalidades entre parentes que concorrem com a mesma mercadoria no mesmo espaço e pelo mesmo público são contadas como sendo recorrentes por interlocutores que geralmente não possuem as mesmas condições comerciais. Esta dinâmica parece configurar também as relações familiares em Beni Naim, uma vez que ali mantém parte de suas famílias em regime de vizinhança. Em certa ocasião, tive a oportunidade de comentar este assunto ao Sr. Youssef que, ao meu ver, sempre inspirava a espontaneidade e franqueza que eu sentia faltar em muitos outros quando eu induzia este tema nas conversas. À certa altura, quando ele contava sobre um filho de um palestino já falecido que possuía muitos imóveis, eu lhe questionei se ele privilegiava os demais palestinos para o aluguel dos imóveis bem localizados para o comércio de confecções, e ele me respondeu o seguinte: "primo não faz negócio com primo, porque os dois são espertos, não aceitam perder ou lucrar menos". A posição de "primo", filho dos irmãos do pai ou da mãe, não significa, necessariamente, relações fortes ou afetivas, pois estas vão depender do pertencimento à “casa”, como se verá no próximo capítulo.

Além disso, o interesse pela performance dos conterrâneos é bem maior do que por qualquer outro concorrente. O fato é velado pela maioria dos entrevistados, e recebe apenas referências brandas que explicam que a opção por não estabelecer trocas comerciais com os “primos" se deve apenas à lógica concorrencial. Segundo esta lógica, a atitude é a mesma com relação a qualquer outro comerciante, especialmente na Marechal Deodoro. Acontece que os aluguéis na rua Marechal Deodoro e adjacências são muito difíceis de conseguir, porque dificilmente alguém abre mão de um ponto comercial nesta localidade. A notícia de um ponto comercial livre certamente gera muita expectativa entre os comerciantes já instalados na área e, por isso, trata-se de uma informação valiosa, como o caso que relata Sandro, conhecedor do ritmo comercial local: 


\begin{abstract}
Acontece da seguinte forma: eles têm a notícia de que uma loja ficará desocupada a espera de novo contrato de aluguel, então cada um corre para alugar o imóvel antes que outro palestino o faça. Chegando com o proprietário eles lançam o preço, e o proprietário diz que outro palestino já lançou um preço maior, eles vão até conseguirem fechar o negócio. Os proprietários não-palestinos dizem que outros palestinos vieram antes porque sabem que farão de tudo para alugar e assim eles conseguem bons contratos, porque pra eles é bem pior perder para um palestino do que para outro qualquer.
\end{abstract}

Outras medidas para solapar a concorrência também são comuns nesse ambiente, como a prática de contratos de exclusividade, e isso vale para qualquer lojista. Estes são feitos geralmente por aqueles que apresentam maior volume de compra e o indispensável conhecimento e confiança do fornecedor. As peças, alvos de contratos de exclusividade, geralmente são as que possuem boa procura. O lojista faz um contrato com o fornecedor destas peças para ser o único a revendê-las naquela cidade, e a única alternativa para aqueles que não têm esse acesso é trazer as mesmas peças para cidades próximas e então levá-las para Manaus. Esta medida parece ser muito comum e, embora causasse certo constrangimento nos interlocutores que a revelavam, esta informação se repetia por quem alegava não proceder desta forma. De fato, os contratos de exclusividade requerem créditos altos, e as fontes dessa notícia não possuíam o porte para competir por contratos de exclusividade.

Estas e outras práticas, seguidas pelas diferentes posições nas redes comerciais, podem responder à evidente desigualdade dos resultados dos projetos migratórios por mim conhecidos. $\mathrm{O}$ acesso às mercadorias populares e em alta, bem como a localização do empreendimento, determinam boa parte do sucesso nas vendas, fatores que dependem, por sua vez, de intermediários e de pelo menos um financiador. Além das tensões promovidas pela corrida por contratos deste tipo, outras são as situações que despertam suscetibilidades e contendas.

As relações de sociedade entre parentes também estão sujeitas a certas regras, uma vez que é estabelecida a partir da hierarquia que se funda no momento do recrutamento, de modo que o "ajudado" não vai apenas dever favores, como também submeter suas decisões à avaliação de seu financiador, principalmente nas situações de sociedade. A situação mais corporificada deste tema árido e difícil de ser verbalizado foi contada por Nasser. Este interlocutor comentava sobre o luxuoso prédio construído em Beni Naim para abrigar as famílias do grupo de Omar e seus irmãos, todos sócios. Segundo Nasser, o projeto foi idealizado pela sua filha, casada com um deles, mas cujo mérito não foi reconhecido, tendo sido atribuído a Omar: “ele tem que ser a cabeça de tudo, né?”. 
A exibição da condição financeira pode se dar pelo capricho com que são construídas as suas casas em Beni Naim, mas também por objetos, como carros de luxo, segundo Nasser. Outra situação de competição acontece nas deliberações do coletivo de homens palestinos sobre as doações. As mulheres não podem presenciar estes momentos porque acontecem após a oração da sexta-feira na Mesquita, no espaço reservado exclusivamente aos homens. Todas as iniciativas de nível coletivo são discutidas nesta ocasião, que exige decoro e o silenciamento das animosidades. Apesar de nunca ter presenciado estas situações, Sandro reitera que no momento das ofertas os palestinos costumam dedicar valores altos, que dificilmente são dados quando lhes é cobrado pessoalmente.

Alguns informantes relatam que as animosidades acontecem há pelo menos 15 anos. Sônia (48 anos), palestina e proprietária de um minúsculo ponto de comércio de confecção com o esposo, alega que antes os palestinos estavam no mesmo "nível econômico" e que por isso não havia conflitos. Mas na medida em que foram crescendo e adquirindo mais lojas, os conflitos aumentaram de modo que até as reuniões e atividades recreativas, que antes eram tradição entre as famílias e que aconteciam na sede da Sociedade, terminaram. A interlocutora também citou práticas que, segundo ela, são para "se dar melhor que o outro", como a venda de produtos abaixo do preço de mercado apenas para prejudicar a concorrência. Para Sônia, isto se verifica na semelhança dos produtos da maioria das lojas dos palestinos.

Esta conduta é reprovada pela informante e por Sandro que também expôs a situação omitida pelos demais interlocutores, inclusive por Ranya que revela ter, ela e o marido, um cuidado especial com relação à adequação das atividades comerciais à prescrição corânica. Ranya contou que entre seu esposo e o irmão, que mesmo não sendo sócios, não há "compra e venda" de um para o outro. Quando um tem condições de comprar a mercadoria do outro (com o dinheiro do outro), não acontece de querer obter lucro nesta ocasião, pois trata-se de uma troca de favores entre irmãos, uma conduta mencionada e prescrita no Alcorão.

Tais situações evocam relações semelhantes às demonstradas por Klaas Woortmann (1990). O autor apresenta um modo de produção do que denomina de "ordem moral campesina", em que as lógicas da reciprocidade e do mercado estão integradas em espaços bem demarcados de vigência das ideias de honra e hierarquia. No contexto estudado, o negócio é visto como negação da reciprocidade, sendo relegado a um plano bem demarcado da vida de seus interlocutores. Não obstante as prescrições contundentes a respeito das 
situações de trocas, vista como um valor que coaduna indivíduos coletivos e entidades hierárquicas em partes moralmente equivalentes, o âmbito do negócio é carregado de ambiguidade pelo fato de possibilitar recursos valiosos para as dinâmicas de reciprocidade.

Esse caso que também é apontado pelo autor como sendo semelhante a outras evidências etnográficas brasileiras que demonstram a compatibilidade entre a produção de valores conflitantes com os da lógica do mercado. Sendo assim, retenho que, por mais que tais acontecimentos pareçam negar a existência de laços de solidariedade, eles não criam, necessariamente, rupturas ou "indiferenças". A recusa em negociar com um "primo" sugere, pelo contrário, a relação de partes moralmente equivalentes, cuja relação está sujeita a trocas, contraprestações ou reparações. As animosidades e conflitos indicam ligações de longaduração, que provam que a "colônia" é constituída não apenas como ideal comunitário, mas principalmente pelo conteúdo "desagregador" das relações de curto termo.

Tais condutas eram difíceis de serem expressas para uma pessoa como eu, por exemplo, de modo que o meu acesso a este caráter das relações aconteceu por pessoas que não sustentam um comprometimento moral com a manutenção de uma ideia pacífica da "colônia". Isto talvez se deva ao fato de estes interlocutores não estarem em condições de equivaleremse às partes daquele nível de concorrência, ou seja, de não serem reconhecidos como entidades morais para trocas desse gênero. Talvez aqui resida o sentido para o diálogo que presenciei entre duas interlocutoras, Carmem e Graça, que são irmãs. A ocasião se deu no fim de um encontro oferecido por Graça para uma amiga de Beni Naim que havia chegado há algumas semanas. Ao final, quando Graça se despedia dos convidados e eu me aproximava para me despedir também, ela se dirigiu à irmã perguntando o porquê de Nasser estar de "cabeça baixa", aparentando tristeza. O diálogo ocorreu mais ou menos nestes termos:

Carmem: É mana, homem quando perde o dinheiro perde tudo, é isso o que acontece.

Graça: É, mas não deveria ser assim, porque ainda tem os filhos, tem a família.

Carmem: Mas essa é a realidade, ninguém mais olha pra ele, ninguém mais nota ele.

Graça: É verdade, quando o meu marido perdeu o dinheiro aconteceu isso mesmo com ele.

Tanto os casos de concorrência como os de cooperação sugerem a equivalência dos sujeitos como seres morais, ou seja, dos quais se espera certos comportamentos. Isto não significa simetria, mas equivalência no sentido de serem reconhecidos como partícipes dos princípios em jogo, e possuidores dos recursos para jogar o jogo. Esta perspectiva é orientada por Bourdieu (1965), nas considerações acerca da honra na sociedade Cabila. Para 
o autor, entre os Cabila a ofensa infligida a alguém desafia o sentimento de honra, cujo procedimento atende à lógica do desafio/resposta, assim como a troca. Feita a ofensa, os Cabila se sentem na necessidade de responder ao ataque e, por isso, esta lógica é portadora da virtualidade do conflito. Por isso o conflito também cumpre uma função para a reprodução social segundo Bourdieu (1965), já que implica em considerações sobre as modalidades dos desafios e de reparação.

Neste sentido, sugiro que o fato de Nasser "não ser notado" pelos conterrâneos, pode advir da condição desfavorável que se encontra para desafiar seus pares com os sinais de prestígio. Isto não quer dizer que Nasser está em falta com outros sinais, pois a sua cunhada lembra que existem outros valores pelos quais pode se orgulhar. Numa situação de conflito não podemos supor que haja possibilidade de opressão total entre indivíduos mas, ao contrário, sua concepção faz aparecer dissenções internas e outras fontes de autoridade, como manifestação das contradições de um grupo. Essas dissenções não seriam a causa de um mal funcionamento ou de relações fracas, mas uma fonte de regulação que pode estruturar relações coletivas provocando o delineamento de identidades sociais. Portanto, dou continuidade a esta discussão na seção seguinte, explorando como alguns casos podem evidenciar dissenções internas ao coletivo de palestinos aqui representados.

\subsection{Um caso exemplar}

Aproveitando o influxo das análises anteriores, pretendo expor nesta seção um dos casos que me fizeram pensar nas contradições que envolvem a manutenção da colônia palestina. Além de existirem outros sinais de prestígios pelos quais estas pessoas concorrem, algumas desigualdades são patentes e informam como se produzem posições privilegiadas na relação de dádiva no âmbito do sistema de "ajuda" para fins comerciais. Da análise aqui proposta, pretendo demonstrar que o tipo do circuito comercial no qual cada empresário palestino do ramo das confecções está inserido determina alguns dos elementos materiais e simbólicos que ele pode transacionar com os demais. Além disso, tento expor como no âmbito da atividade comercial se delineiam diferenças entre as relações travadas e recursos transacionados com palestinos e com locais, para demonstrar que essa prática produz identidades sociais. 
Para tanto, abro um parêntese aqui para etnografar como funciona uma rota específica de confecções no Brasil, e apresentar a experiência de um casal de lojistas palestinos que se beneficiam deste circuito. A rota das confecções do tipo "sulanca", termo cuja origem remete a roupas de qualidade inferior, é percorrida por Fernando Rabossi (2008), a partir do polo onde o produto encontra este significado: o Polo de Confecções do Agreste Pernambucano, o segundo maior polo de confecções do Brasil, atrás apenas de São Paulo. A rota da "sulanca" é um exemplo de "globalização popular", ou de um "sistema mundial não hegemônico" (Ribeiro, 2010), que contempla práticas econômicas que atravessam países fora dos marcos legais.

Segundo o autor, a maior feira revendedora deste tipo de confecção, localizada na cidade de Santa Cruz, no agreste pernambucano, tem reconhecida articulação com os estados do norte e nordeste, que tem seus mercados abastecidos pelos "sacoleiros", mediadores fundamentais para distribuição da "sulanca". A categoria "sacoleiro" faz alusão à sacola na qual as pessoas realizam a circulação dos produtos. Tais pessoas maximizam os lucros na medida em que detém o controle da disponibilidade dos produtos em outras regiões menos privilegiadas em termos de integração, por exemplo, como é o caso de Manaus. Segundo o autor, a competência comercial exigida por um "sacoleiro", assim como toda competência comercial, não tem um caráter definitivo e pode mudar ao sabor das diferentes conjunturas econômicas e políticas.

Quando perguntados sobre a origem dos produtos comercializados, a maioria revela adquiri-los diretamente das fábricas nas cidades de Recife, Ceará e São Paulo, e que os produtos de origem internacional (principalmente oriundos da China por meio de entrepostos como o Panamá) são conseguidos através de representantes. Pude perceber muitas mercadorias com essa origem internacional. Certa vez fui informada que a venda de mercadorias provenientes da China é um negócio muito lucrativo, pois são compradas por quilos que custam centavos. Não por acaso o palestino de maior progressão financeira dos últimos anos possui um escritório próprio naquele país, gerenciado por um irmão. $\mathrm{O}$ fato não foi mencionado por nenhum deles, exceto por Nasser. A presença de mercadorias chinesas pode figurar como indicador de alta lucratividade, mas também pode apresentar um lado obscuro, uma vez que estão sujeitas a um tipo de fiscalização mais rigorosa.

Foi graças ao meu diálogo com Ranya que pude entender alguns pormenores desse ramo da atividade comercial. A relação com a interlocutora teve início na ocasião das aulas de árabe ofertadas pela mesma aos partícipes da "colônia" e demais interessados em aprender o idioma. A classe era composta sobretudo por adolescentes em que parte da família é 
brasileira, e mulheres brasileiras que tem algum tipo de envolvimento com palestinos ou "árabes". Os nascidos de pai e mãe "palestinos" com maior envolvimento com a língua, e demais homens interessados no idioma e no estudo da religião, frequentavam as aulas ministradas pelo sheer num outro dia. O convívio semanal com a turma me possibilitou várias das principais incursões no "campo" propriamente dito, constituindo uma boa oportunidade para me fazer conhecer e conhecer a colônia pelo viés dos nascidos no Brasil.

Ranya se mostrou solícita para me esclarecer o que ela entendeu como sendo "coisas da cultura palestina". Seus modos distintos, bem como a fala bem articulada, denotam uma inteligência digna de uma legítima representante da "Ramallah". Ranya é uma das poucas mulheres que conheci em campo que acompanham o marido no trabalho, primeiro porque tem a permissão dele, e segundo pela falta de condições do casal para suprir a demanda por funcionários para as duas lojas que devem administrar. Sendo assim, pude compreender um pouco das dinâmicas comerciais principalmente porque com ela eu tinha mais oportunidades para diálogos informais, possibilitados pelos convites que eu recebia para, por exemplo, almoçar em sua casa ou acompanhá-la no dia-a-dia da loja, coisa que nenhum palestino houvera feito.

Para mulheres como Ranya, que devem enfrentar uma jornada de trabalho que inclui atendimento ao cliente, controle de estoque, pesquisa e compra de produtos, atenção aos funcionários, esposo, filhos e o cuidado com a alimentação e com a casa, a intensidade da experiência com o "Brasil" só não é absoluta graças aos vínculos com a Palestina alimentados principalmente pelas redes sociais. A mesma conta que antes de ter acesso a este tipo de tecnologia, a terra e a religião pareciam "estar muito longe", de modo que o próprio hábito de usar o véu foi adquirido aqui quando começou a participar de comunidades virtuais de mulheres muçulmanas. A atividade comercial e a utilização da tecnologia para estes fins fazem de Ranya um caso de estilo de vida não muito comum no meio representado aqui.

A vinda de Ranya para o Brasil se deu pelo casamento no final da década de 1990, para acompanhar o marido que já trabalhava em uma das lojas do irmão que fica nas adjacências da Marechal Deodoro. Sendo assim, o casal não conseguiu se inserir no circuito de vendas daquela rua, e por isso existem nítidas particularidades em seus negócios. Uma de suas lojas dista menos de 500 metros da rua Marechal Deodoro, o que já é suficiente para atrair um público diferente. 
Figura 5 - Localização da Avenida Marquês de Santa Cruz.

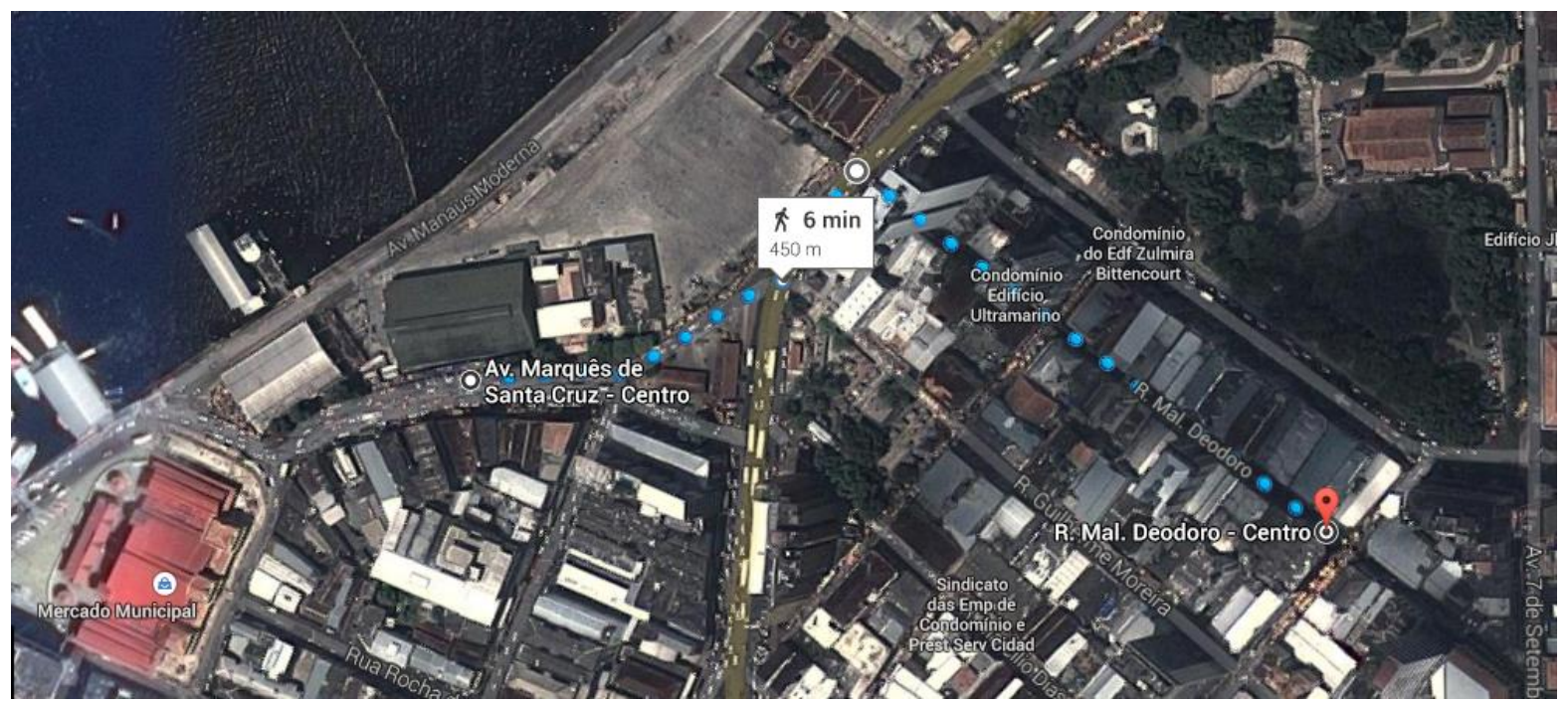

Fonte: Google Maps, Março de 2015.

Ranya conta que a maioria dos clientes da loja são do sexo masculino, menos exigentes e menos dispostos a gastar muito. A loja recebe sobretudo pessoas do interior em trânsito na cidade, que aproveitam as imediações do porto para incursões rápidas e objetivas no comércio. O padrão difere do encontrado na rua Marechal Deodoro nem tanto pela qualidade das mercadorias, mas pelo seu aspecto. Na Marechal Deodoro as lojas oferecem modelos mais baratos de estilos em alta na moda nacional, costumam ter, por exemplo, peças que acompanham tendências lançadas por personagens de novelas nacionais. Ao contrário da Avenida de Santa Cruz, a Marechal costuma receber pessoas oriundas de toda a Manaus.

Na Rua Barroso, que fica um pouco acima da Marechal, Ranya tem uma loja num prédio do tipo "galeria". Ali a interlocutora recebeu orientações de que os clientes são mais exigentes, o que a força para uma adaptação a um outro circuito de compras. O ponto comercial foi conseguido apenas porque a proprietária da galeria é uma amiga da família, viúva de um "árabe" que possuía relações estreitas com a colônia. Visto não terem experiência com esse tipo de consumidor, Ranya e o esposo lutam por conseguir acesso às mercadorias adequadas, o que é muito difícil uma vez que não possuem avalistas morais e nem crédito suficiente, de modo que continuam tendo que abastecer a loja com roupas de "feira".

Presenciei Ranya compartilhando suas experiências de trabalho com uma amiga, Leila, e a esposa de um cunhado. Essas três mulheres são ativas no comércio, assumem diariamente as lojas que possuem com seus respectivos esposos. Estas mulheres são amigas e compartilham muitos momentos juntas e sempre promovem ocasiões para estarem próximas. As três se 
queixam da atividade no comércio, que é muito cansativa, principalmente quando tem que assumir completamente as atividades domésticas. Nas conversas que pude participar, as três se apoiam e compartilham muitos sentimentos relacionados tanto aos negócios como à família, e efetivamente se consideram uma mesma família. Sendo assim, muitas ideias e mercadorias passam no fluxo dessa amizade, o que não ocorre com os demais empresários palestinos.

Em um dessas conversas, que se dava no interior da loja de Leila, Ranya declara não saber que funcionária escolher para ajudá-la na loja que inauguraria em breve, já que não confia em nenhuma das que dispõe. Leila recomenda bastante segurança e energia no trato com as funcionárias, disse para Ranya fazer o mesmo, "não dar confiança", para que as funcionárias não a desrespeitasse. Leila também acrescentou que não se pode confiar em nenhuma delas, pois nenhuma é "boazinha". Esta interlocutora informou que recebe muitos currículos, mas que quando procura as pessoas para contratar ninguém se interessa, porque, segundo ela, "o manauara não quer trabalhar". As três concordam em entender que a falta de trabalhadores sérios se deve a este caráter da população, o que pude presenciar quando Leila repreendeu uma funcionária acusando-a de fugir ao trabalho, preferindo "bater perna por aí".

Da parte dos funcionários, tive a oportunidade de obter alguns pontos de vista, dentre os quais destaco o da proprietária do apartamento que eu alugava em Manaus, Verônica. Certa vez, quando eu comentava com ela sobre a quantidade de "árabes" no comércio, ela torceu o nariz com visível irritação, começou a falar com mais força e imprimiu indignação na voz, num tom bastante acusatório das práticas destes comerciantes que se destacam pelos modos particulares com que vivem naquele espaço:

Árabe? Esse povo? É o que mais tem ali! Eles são muito ruins, nem respeitam dia santo nem nada, abrem o comércio até dia de domingo e quando é pra mandar embora eles não tem pena não, eles dão a conta mesmo. Eu sei porque a minha irmã já trabalhou pra um deles.

Como cliente, Verônica ainda falou sobre o modo de negociar que para ela é próprio deles. Contou que possui um amigo árabe que costuma baixar o valor das mercadorias quando o cliente diz ter visto o mesmo produto a um preço mais baixo. Seu filho, que coincidentemente aluga um dos imóveis do Sr. Omar, acrescentou que eles são "ruins" nos negócios, no sentido de cobrarem valores muito altos e não pagarem suas dívidas. Estes relatos exemplificam o fato de que a lógica econômica empregada com os locais não atende ao mesmo princípio identificado nas relações entre pares, uma vez que neste último a pecha de "mau pagador" é um insulto moral, de modo que as dívidas contraídas nesta lógica atendem à necessidade de contraprestação. 
Do mesmo modo, o relacionamento que se tem com os funcionários não é avaliado nos mesmos termos do que se espera entre palestinos e, sendo assim, outros conselhos e situações cotidianas passam no fluxo da amizade de Ranya, como dicas sobre o quê e como vender, e revelam um caráter da assistência entre famílias. Certa vez, Ranya comentou sobre os negócios que realizava com uma prima do esposo nascida no Brasil. Durante certo período Ranya disse comprar com frequência seus produtos, pois recebia vantagens na forma de pagamento: "pra mim ela fazia assim, vendia por consignação até, os produtos que sobravam eu devolvia". A prima possui muitas características do que considera como sendo "brasileiras", principalmente porque não é muçulmana e não casou com um palestino, embora seu pai tivesse sido um partícipe ativo da colônia.

Embora eu tenha utilizado o princípio elaborado por Woortmann (1990) para expressar uma situação em que "com parente não se negocia", nos casos relatados aqui fica clara a negociação entre parentes, pois esta é a condição para trabalharem como sócios. Mas a situação de parentalidade demarcado por Woortmman (1990) pode equivaler aqui à condição de "primo", já que muitos são primos uns dos outros em algum grau. Dito isto, observo que com os locais se pode lançar mão de várias táticas de persuasão ou de obtenção do maior lucro possível, e que estas táticas obedecem a uma lógica concorrencial oposta à lógica da dádiva.

Como discuto anteriormente, as relações entre palestinos estão sujeitas a determinadas expectativas, como a de honrar dívidas, reconhecer e ser grato pela ajuda recebida ou ainda reconhecer-se como devedor de recursos incalculáveis por um tempo indeterminado. Por isso fica difícil conciliar a economia da dádiva com a economia de mercado nas transações comerciais cotidianas, pois, como disse Youssef, "primo não faz negócio com primo, porque os dois são espertos, não aceitam perder ou lucrar menos”. Como dita a lógica do desafio/resposta elaborada por Bourdieu (1965), a colônia pode ser entendida como a grande expectadora e coativa da atenção que se deve às prescrições, que são coroadas com sua realização em grupo, em situações de reconhecimento público da ordem transacional requerida. Sendo assim, passo à análise mais específica das atitudes que contribuem para a manutenção desta ordem. 


\subsection{Purificando o dinheiro}

Atitudes positivas para a manutenção da "colônia palestina" emergem no cumprimento de expectativas religiosas ou civis, nas doações demandadas pela religião e mobilizadas em grupo, nas contribuições para obras sociais e demais investimentos em benfeitorias públicas em Beni Naim, etc. Tudo isto sugestiona a composição de subjetividades comprometidas com um interesse comunitário moldado fortemente por princípios religiosos. Para tanto, diz a regra que devem saudar uns aos outros e dar o melhor que puderem quando for necessário, por mais que, depois, longe dos processos decisórios, seja difícil extrair as quantias voluntariamente acertadas em público.

Exemplo disto foi o desencontro dos pontos de vista relativos à "ajuda" organizada pela colônia para a família que havia chegado da Síria, em meados de abril. Um casal jovem com três filhos pequenos e acompanhados do tio, irmão do pai, teve que pedir refúgio devido a onda de conflitos que assolam o território sírio. Segundo a esposa, as autoridades estavam perseguindo pessoas de origem palestina, justamente a origem do marido, dado o envolvimento de milícias palestinas nas ações contra o governo. O Brasil foi o primeiro país a conceder o refúgio. Depois de uma breve temporada na Malásia, a família desembarcou em São Paulo e foi recebida por autoridades islâmicas do estado. Ao saberem da origem do chefe da família, um vilarejo próximo a Beni Naim, os refugiados foram enviados para Manaus, onde encontrariam "proximidade cultural" com os palestinos dali.

A família foi instalada nas dependências da Mesquita, tendo recebido o mobiliário indispensável para passarem os primeiros meses. Nas ocasiões das aulas de árabe, Ranya sempre aproveitava para visitar a mulher refugiada e eu pude acompanha-la várias vezes nessas visitas, de modo que eu ficara relativamente a par da situação. Na semana seguinte ao ocorrido, enquanto eu passava pela frente da loja de Fauzi, depois de uma saudação efusiva, ele começou a relatar o caso após a minha manifestação proposital de um conhecimento superficial do ocorrido para saber a sua versão dos fatos, o que não deixava de ser verdade uma vez que as minhas conversas com a mulher refugiada eram sempre mediadas por Ranya.

Fauzi se mostrou inteirado das circunstâncias de chegada da família, e concluiu dizendo que já haviam conseguido um apartamento para alojar a família, um dos apartamentos vagos do Sr. Farid, que seria gratuito até que o pai conseguisse um trabalho, pois o mais jovem e solteiro, tio das crianças, já estava trabalhando na sua loja como vendedor. Fauzi expressou sua indignação com a situação dos refugiados da guerra da Síria, 
disse que 70 famílias estavam na mesquita de São Paulo. Ele se referiu aos refugiados como irmãos, e declarou a obrigação de ajudá-los como compromisso da fé islâmica. Mas várias semanas se passaram e a família continuou na Mesquita. Até o meu retorno, que se deu em meados de julho, a família não havia sido realocada.

Perguntei a outros dois interlocutores se haviam tomado conhecimento do caso, Jamal e Youssef. O primeiro disse que as medidas estavam sendo tomadas, mas que não havia participado da reunião para definir esses assuntos. O segundo disse que primeiro tinha chegado um aviso de São Paulo comunicando-os a respeito da família, e o informe foi repassado durante a reunião da Salat na Mesquisa, que acontece todas as sextas-feiras. A Salat é um momento de encontro da colônia para a oração e discussão de temas de interesse coletivo. Assim que a família chegou, Youssef conta que eles (a colônia) haviam providenciado o aluguel de um apartamento, a mobília e trabalho para os homens, e combinaram para que cada família desse aquilo que podiam para a consecução do acordo, designado três pessoas para coletar o dinheiro.

Ranya continuava acompanhando a situação da família, principalmente da mulher que era com quem conversava e auxiliava em algumas questões. Certa vez, em uma de nossas conversas, ela disse que a família ainda não se mudara porque todas os valores dos aluguéis apresentados eram altos, e o chefe da família só aceitava morar em um lugar que pudesse pagar com o seu trabalho. O acompanhamento deste caso me ajudou a visualizar um tipo de ocorrência da "ajuda", elucidando questões sobre o sentido filantrópico e religioso das ações coletivas e individuais, bem como das implicações morais reveladas sobretudo na recusa do chefe da família em morar às custas dessa "caridade".

Em campo, conheci por acaso a ex-esposa de um dos irmãos de Farid, que não cheguei a conhecer, dado que sua presença na cidade não havia sido mencionada. Esta interlocutora se dispôs prontamente a colaborar com a pesquisa, o que ajudou a ampliar algumas de minhas questões, dando-me condições para visualizar mais complexidade na argumentação reiterada sobre o trabalho dos primeiros imigrados e suas relações:

Eu: E no caso do seu esposo ele veio porque já tinha algum parente aqui né?

Fátima: Ele veio fugindo da guerra, a guerra de 67 se eu não me engano. Por que queriam que ele servisse, que ele fosse pra frente de batalha e a mãe que não deixava ele ir. Porque se fosse, morria. Aí o irmão dele, parece que foi até o Farid mesmo, mandou buscar ele. Aí mandou buscar ele e ele veio.

Eu: Ele começou trabalhando pra ele, né?

Fátima: Eles começam assim, sempre trabalhando pro irmão. Porque não tinha de onde tirar mesmo né! Tinha que ajudar o irmão. É tipo assim, eles consideram tipo uma ajuda, mas aí depois de um certo tempo, aí aquele carinha que te ajudou, aí separa uma parte e 
já dá pra ele e "isso aqui é pra você se virar”, né. "Correr atrás do que é seu também". Aí foi assim que, aí é assim que eles vão construindo, chamando as pessoas.

Eu: Mas aí quem é ajudado se sente na obrigação de pagar?

Fátima: Não, não! Principalmente ele no caso, que era irmão né. Eu acho que não, porque eu nunca me meti em negócio, porque eu era a pessoa mais besta do mundo! Eu não me metia, não sabia de nada, não queria nem me envolver. Porque não adiantava, tipo assim, ter uma briga de dois irmãos bem ali e tu defender um. O outro fica é com raiva de ti, fica talvez até os dois com raiva de ti, mas depois estão juntos, entendeu? Mas eu nunca me meti não, sempre deixava pra lá. Ele vinha, chateado, às vezes me contava alguma coisa da família, mas ficava bem ali mesmo, eu nem dava conselho. Eu não me envolvia! Tipo assim: ah, faz isso, ah tem que fazer aquilo! Porque não dá pra se meter não, que eles são muito unido mesmo. Entendeu?

Eu: E o que a senhora quer dizer com o Sr. Farid ter mais reconhecimento antes, porque que ele tinha mais moral?

Fátima: Tinha porque, tipo assim, ele era o mais cabeça, ele que orientava os outros, entendeu? Todo mundo respeitava ele, acho que até hoje deve respeitar, não sei como é a vida que aconteceu por aí, porque eu também saí daqui faz muito tempo. Não sei nem como é que tão eles. Eu só sei que antigamente quando eu morava aqui, ele era uma pessoa muito respeitada, por todos eles, até pelos irmãos, primos, todo mundo, tinha o maior respeito por ele. Quando alguém queria fazer alguma coisa e tava em dúvida, corria lá pra cima dele pra pedir orientação, entendeu? Ele era desse jeito.

$\mathrm{Eu}$ : Porque ele tinha os melhores conselhos?

Fátima: Também, ele orientava bem melhor. Até pessoas que não faziam parte da família dele mas eram da mesma cidade, sempre eu observava isso, eles se comunicando, tudo o que queriam era pedindo tipo um conselho: será que se eu fizer isso vai dar certo? Ou fizer aquilo outro... Era assim.

Eu: Com relação ao negócio e família?

Fátima: Pra família também, ele era desse jeito. A minha família mesmo, quando eu tava pra me separar, muitas vezes eu mesma corria pra cima dele. Não corria no sentido de dizer: ai, me socorre. Não."

O relato expõe parte das características das interações familiares entre irmãos, e de como pessoas com reconhecido destaque na atividade comercial podem alcançar certos privilégios, como o de ser procurado e ouvido. Mas Fátima conta também algo da proximidade entre os conterrâneos, fato narrado por outros interlocutores. Antes, a chegada de alguém da terra mobilizava toda a colônia, que costumava se reunir com mais frequência para a discussão do destino dos imigrantes novos e até para discutir sobre questões relativas ao âmbito doméstico, como ameaças de divórcio, casamentos etc, havendo muito esforço no sentido de casarem os homens com mulheres palestinas, para garantir um "lar palestino".

Alguns atribuem a atual "individualização" das famílias pelo aumento de seu número nas últimas décadas. Contemporaneamente, são mais de 300 famílias reconhecidas pela Sociedade como "famílias palestinas", e é natural, para alguns, que as pessoas, principalmente a nova geração (que corresponderia aos netos dos primeiros imigrantes) não tenham relações mais próximas. Dona Graça expressa seu descontentamento com a situação atual da colônia: 
Desses árabes todinhos, de quem eu vi muita coisa boa foi do meu marido, eu queria era ver, um árabe desse, na loja dele, se ele não saia com duas ou três mudas de roupa. Hoje em dia você vai na loja de um árabe desse e você não pega uma blusa. Além de ele (o marido) mandar muito dinheiro pra mãe e pros irmãos.

Segundo um dos representantes para assuntos religiosos, Ismail, a Associação deixou de ser frequentada principalmente por conta da distância e de que hoje em dia existem muitas outras opções de lazer, já que atualmente a maioria dos palestinos têm acesso a outras opções por conta da situação financeira. Apesar de ser contra a ideia de que o abandono da Associação tenha sido por conta da concorrência, Ismail reconhece que isso teve bastante influência ao falar do papel da Mesquita na agregação atual dos palestinos. O espaço de convivência agora é religioso, o que segundo ele impede animosidades em momentos que não são os do trabalho, pois ocorria muito de famílias deixarem de ir para a Associação porque estavam brigadas com alguma outra família.

Ismail acredita que esse é o benefício da Mesquita, pois agora não podem mais evitar o contato uns com os outros porque o encontro ali é com Deus e mais ninguém, e lá devem cumprimentar seus irmãos. Ranya também não alimenta a ideia de que o desuso do espaço de recreação foi ocasionado pelas contendas entre famílias. Mesmo diante de Sônia que também participava da conversa e não concordava com esta visão dos fatos, ela insistia dizendo que as pessoas foram perdendo o interesse porque o caseiro responsável pela manutenção foi deixando de cuidar do lugar, de modo que as mulheres passaram a não querer mais levar suas crianças que estavam contraindo doenças de pele ao brincarem na areia ou na grama. Ranya comenta com muita saudade dessa época, diz que até os "filhos de árabes" (os que não guardavam os costumes e nem a religião) frequentavam o lugar.

O processo tido como de "individualização" das famílias de migrantes carrega o pressuposto de que o deslocamento implica a superação de uma "ordem social originária" rumo a uma "nova ordem social". Segundo esta perspectiva, ao se desfazerem das lealdades de origem, os migrantes são tentados a desenvolver um processo de desprendimento e individuação dentro de contornos cosmopolitas. A situação se revela muitas vezes dramática e vivenciada como um dilema moral, pois as possibilidades de trânsito na nova estrutura social remetem a uma redefinição do sistema de relações com novas configurações de papéis sociais, nem sempre fáceis de serem negociadas.

Creio que, com base no quadro empírico exposto até aqui, seja difícil falar em termo de rupturas, abandonos ou escolhas. O processo de inserção de palestinos recém-chegados no 
circuito comercial parece suficientemente balizado por expectativas de lealdades de natureza diferente das pressupostas pelo ideal de selfmademan, pois apresenta a participação ativa de uma moralidade compartilhada por seus conterrâneos. As ações econômicas não são senão possibilidades negociadas dentro de critérios de reciprocidade entre parentes e do princípio redistributivo do dinheiro como responsabilidade transcendente, nas quais emergem obrigações, hierarquias e respeitabilidades.

É dentro deste contexto que o dinheiro ganha significação especial pois, não obstante seu caráter reconhecidamente impessoal, ele participa aqui de transações entre entidades morais que se lhe fazem uso para relações com efeitos de curto e longo prazo. O dinheiro é, portanto, "pessoalizado", ou seja, pode ser a representação de alguém ou de alguma coisa ou evento, representação de algo que lembra afeto, obrigação, responsabilidade, ou qualquer fato que lhe dê outro sentido que não o da simples mediação. Para entender as narrativas triunfalistas ou os casos de prestígio, convém perceber que o dinheiro é um forte elemento classificador da sociedade moderna, no seu potencial infinito para garantir coisas e valores que incorporam o desejo da maioria dos indivíduos.

Silva (2008) aprofunda esta discussão numa curiosa análise sobre as doações entre Estados-nações que atuam no campo da assistência ao desenvolvimento internacional (AID) e da ajuda humanitária, e tem como foco a economia da dádiva realizada como estratégia de poder pela comunidade de doadores em Timor Leste. Para a autora, as doações de dinheiro, equipamentos e pessoas nas situações de assistência e ajuda entre países tem grande força ou efeito moral, no sentido de gerar um penhor moral que coloca o Timor Leste em estado de subserviência a interesses estrangeiros.

A autora demonstra o seu argumento a partir de uma análise que perpassa os rituais de ajuda e prestações de conta nos quais os representantes dos Estados disputam diferentes projetos civilizatórios com vistas a alcançar efeitos de poder. Silva (2008) sublinha que isto se dá a através da personalização dos bens ofertados, que passam a ser identificados pela sua origem nacional. As próprias autoridades timorenses encarregadas de participar dos acordos também atendem às expectativas de reconhecimento insinuadas pelo espetáculo da oferta de bens, que também apresenta nítidos sinais de uma disputa pela maior quantia ou melhor serviço prestado.

Os recursos doados atuam no processo de construção das identidades dos Estados doadores, pois cada país privilegia os projetos aos quais querem associar a própria imagem. Para os agentes envolvidos, a doação também é interpretada como um meio para saldar dívidas históricas, haja vista que a maioria participou dos empreendimentos coloniais que teve 
influência negativa para história do Timor Leste: “do ponto de vista desses atores, a dádiva internacional é interpretada como um meio de se saldarem dívidas históricas, veículo através do qual certos países procuram recompor sua moral diante do mundo por ações ou omissões praticadas para com Timor Leste" (SILVA, 2008, p. 158)

A economia da dádiva implica, portanto, na transferência da personalidade daquele que doa, uma vez que as expectativas de retribuição e reconhecimento acompanham o objeto intercambiado, e devem ser cumpridas pelas devidas formas e no devido tempo. Dentro destas expectativas, têm-se as formas propriamente materiais de compensação, mas principalmente a do reconhecimento de que a ajuda foi indispensável, já que se configura no único meio para a "progressão de vida". Tais relações são essenciais segundo alguns interlocutores, que não veem outra forma de conquistar um espaço no comércio:

Ismail: O mercado brasileiro já tá vacinado, ele não permite mais aventureiro.
Antigamente o mercado absorvia aquela pessoa igual ao meu pai que chegou
mascateando. Ele saía com duas bolsas, vendendo de modo ambulante, e ele teve a
oportunidade de crescer. Hoje não, hoje você não tem mais essa condição. O
estrangeiro que tentar trabalhar no Brasil pensando que vão colocar duas malas no
braço e vai sair e vai crescer, realmente ele vai ser uma exceção da regra. Porque
hoje o mercado não absorve mais esse tipo de aventura. Então quem vem de lá já
vem de modo meio que dirigido. O seu comércio tá expandindo, eu preciso de
pessoas de confiança então eu começo a recrutar. Não é nem a iniciativa de quem
está lá vir, é de quem está aqui convocar. Não é nem um convite, ele convoca. Ele
liga pro irmão e pergunta 'o que você está fazendo aí?'. 'Ah, tô trabalhando e tô
ganhando x'. Então venha pra cá que você vai ganhar mais e você é da minha
confiança'. Entendeu?

O fato de o irmão já estabelecido em Manaus poder "convocar" e não "convidar" se dá, talvez, pela autoridade conquistada mediante a obtenção de mais recursos para prover as necessidades da família na Palestina, e nestes casos os repasses se estendem aos pais e irmãos homens, solteiros e casados. Não há uma regra em relação às características daquele que migra para trabalhar, a única verificada é a de que todos são homens. Tanto os mais velhos como os mais novos na hierarquia agnática ocupam posições confortáveis e viabilizam ou viabilizaram a conquista para irmãos, filhos, sobrinhos e em alguns casos para cunhados. Ocorre por exemplo, de pai e filho se igualarem na posição de auxiliados, como aconteceu com Jamal que foi convocado ao mesmo tempo que seu pai para trabalharem na rede de lojas do tio, irmão do pai.

Diante disto, sugiro que foi através das relações mediadas pelo dinheiro que a colônia conseguiu adquirir os contornos atuais, pois garantiu a presença da Palestina ainda que ausente em termos físicos, pela prática de "puxar" parentes. Sobre os contornos atuais identifico relações duráveis de bastante interesse para estes interlocutores, com efeitos de 
reprodução de longo prazo. Assumo que o dinheiro é purificado quando se transforma em dádiva, e se dá pela sua transação como "ajuda" e pela sua transferência em prol da Palestina, podendo assumir os contornos da prescrição corânica do tributo (zakat), que significa literalmente "pureza"

A zakat é uma contribuição obrigatória a ser cumprida pelos muçulmanos em benefício de toda a sociedade, podendo ser distribuída inclusive como bolsas concedidas a estudantes e pesquisadores muçulmanos. Alguns interlocutores apenas definiam a zakat como a obrigação anual que todo muçulmano tem de ajudar os pobres e necessitados, mas num pequeno livro presenteado a mim por Ranya e que circulava na Mesquita à época, intitulado "Islam em foco", a zakat é descrita como sendo dirigida preferencialmente aos muçulmanos que precisam de auxílio em diversas situações elencados no Livro sagrado.

A prática de "puxar" parentes não foi traduzida nos termos da zakat, e nem a "ajuda" que isto implica foi descrita nestes termos, pois, como explicitou Youssef, não se trata de um dinheiro "dado". No entanto, algumas narrativas carregam um senso de irmandade ao se falar em outros tipos de ajuda, como sugere a justificativa de Fauzi sobre o auxílio à família refugiada. A colônia organizou algumas doações anuais dirigidas à população carente de Manaus, na forma de brinquedos para crianças pobres, gêneros alimentícios e auxílio aos atingidos pelas enchentes. No ano passado, devido à intensificação dos ataques israelenses na Faixa de Gaza, tive a notícia de que a zakat se deu na forma de transferência de dinheiro para os atingidos pelo conflito.

Curiosamente, o livro "Islam em foco", de autoria de Hammudah Abdalati (2008), aponta que "se o que é devido aos pobres for bem administrado e distribuído aos legítimos beneficiários, a riqueza será pura e legítima. O capital limpo e os bens honestos são as primeiras condições para a prosperidade e transações corretas" (ABDALATI, 2008, p. 122). Quando adquire o sentido de zakat manifesta a separação dos regimes de troca, marcando um tipo de purificação que atua na manutenção de uma ordem de prescrições e normas moralmente aceitáveis para a organização social extensiva à comunidade religiosa. Apesar de não ser entendido como "ajuda", os empréstimos também marcam sistemas de transação diferentes e processos transformativos.

Por isso quando inquiridos sobre as ajudas genéricas, quando eu não especificava o doador e o receptor, alguns interlocutores reiteraram que não se espera retorno, como Jamal e Youssef. Este último disse que se trata de uma "caridade", e que quando dá nestas circunstâncias ele "entrega a Deus". Para este interlocutor, a "caridade" e as "ajudas" entre 
palestinos e sócios são bem diferentes. No primeiro caso não se espera o retorno na mesma forma da doação, em dinheiro por exemplo, e por isso a "ajuda" à família refugiada é um caso de "caridade", já que de nenhum destes interlocutores ouvi alguma expectativa de retorno financeiro, embora outros tipos de retornos não declarados possam ser esperados.

A relação entre estes palestinos com o chefe da família recém-chegada que também é palestino ficou em suspenso para mim. Esta família possivelmente passará a integrar a colônia, e por isso essa relação ficou meio obscura para mim, pois se de um lado os meus interlocutores insistiam na "caridade", por outro, o chefe da família refugiada recusava ajudas mais ostensivas, alegando que só receberia aquilo que pudesse pagar com a renda de seu próprio trabalho. Infelizmente não tive oportunidade para esclarecer estas implicações diretamente com ele, de modo que posso apenas cogitá-las tendo em vista os dados sobre as trocas entre os palestinos da colônia.

No segundo caso o retorno faz-se obrigatório, tanto em dinheiro como em reconhecimento, e explicita uma relação em que o receptor se vê diante de uma dívida moral. Como já foi discutido nesta dissertação, o dinheiro transacionado nestas circunstâncias é um “empréstimo", mas esta ajuda também requer transferências de saberes e outros tipos de apoio como moradia, alimentação e etc., de modo que a dívida total acaba sendo incomensurável e "eterna", como explicitou Nasser narrando o seu caso de dívida para com Farid. Neste sentido, a posição de doador revela um prestígio que se expressa pelo dom de poder ajudar, que é destacado em detrimento da expectativa de retorno nas narrativas de pessoas como Farid, por exemplo.

Além de ter "puxado" muitos dos interlocutores que eu represento na minha argumentação, Farid assume papel importante na consecução das atividades de interesse da colônia: ele não apenas possui o dom de ajudar novos empresários, mas de contribuir para a efetivação de interesses públicos do seu país. Prova disso são suas articulações narradas em prol da embaixada Palestina no Brasil. Quando o antigo embaixador da Palestina no Brasil renunciou ao cargo (pois não concordou com o acordo de Oslo e se negou a aplicar as novas diretrizes da ANP) as atividades da organização enfraqueceram, também devido aos efeitos da guerra do Iraque, um dos principais países a ajudar na manutenção da população palestina no território. Nesse contexto, a Autoridade Palestina não pôde mais custear as despesas com embaixadas, resolução tomada pelo próprio Yasser Arafat em um comunicado por escrito à Representação no Brasil. 
Diante disto, O Farid e outros palestinos de Manaus tiveram a iniciativa de reorganizar a embaixada custeando as despesas. Segundo Farid, à época muitos já eram bem-sucedidos e que atualmente, apesar de serem a segunda maior comunidade de palestinos do Brasil em quantidade, constituem a primeira no somatório das rendas. O combinado no início era de que cada sociedade se responsabilizasse pelas despesas de 1 mês do ano (se fossem doze colônias). Eles negociaram diretamente com as autoridades responsáveis na Palestina por esses assuntos e conseguiram fixar uma ajuda para cobrir as despesas mensais que eram de 14 mil dólares. A colônia de Manaus chegou a pagar mais que isso, mas a iniciativa não teve sucesso porque as outras sociedades não conseguiam arrecadar a mesma quantia.

Farid enfatiza que a sociedade de Manaus foi a única a promover, individualmente, viagens de políticos e jornalistas para a Palestina. Mas o interlocutor enfatiza que são distintos dos demais palestinos radicados no Brasil porque, pela influência do "caráter amazonense", aprenderam a ser mais amáveis, amigáveis, e por isso são tratados com cerimônia em Brasília, têm boas relações com o atual embaixador, e são recebidos pelo primeiro escalão das autoridades Palestinas naquele país; são tratados ali com muito respeito pois muito fizeram pela manutenção da embaixada.

Em muitos pontos da conversa, o Sr. Farid se referia sempre às organizações internacionais palestinas ou à embaixada como um lugar que providenciaria o que estivessem precisando "para resolver algum problema"; Perguntei-lhe que tipo de problema seria resolvido e ele respondeu dizendo que se tratava basicamente dos trâmites para o reconhecimento da cidadania palestina, como a emissão do passaporte por exemplo, e citou o caso da filha de Fauzi, que possui o passaporte brasileiro, mas que "por debaixo dos panos", já que o Brasil não admite a binacionaldade, também possui o palestino.

Como expus acima, a criação da Sociedade Árabe-Palestina de Manaus foi o primeiro ato coletivo para o cultivo de uma sensibilidade palestina no espaço público. Tal iniciativa foi movida pelas necessidades de mobilização conjunta para atender as mais diversas demandas do país de origem. Isto porque há um senso recorrente entre meus interlocutores de que nem as obrigações familiares cessam com a emigração. Importante notar que as próprias autoridades políticas e beneficentes da Palestina contam com esta disposição e se dirigem diretamente a alguns empresários palestinos de Manaus para solicitar as contribuições de que precisam. Youssef declara já ter doado desta forma, quando foi procurado por representantes de ONG's e pela própria prefeitura de Beni Naim, porque sabiam que ele possui recursos para tal. 
Estes mecanismos de vinculação com a Palestina são bastante significativos para as dinâmicas do país, uma vez que, segundo Omar, toda família palestina possui parentes fora que se distribuem em vários países, de modo que em cada família, pelo menos 2/3 dos integrantes encontram-se no exterior. Esta proporção também é medida de outras formas, como a que ouvi posteriormente do mesmo interlocutor, de que "para cada três palestinos dentro do território, existem quatro que estão fora". Esses dados reforçam os discursos que pretendem fundamentar ou justificar as transferências de ajuda para a Palestina, que são articuladas com a necessidade de resistência no território.

A "nação" é evocada e importa trabalhar em prol de sua manutenção. As transferências em dinheiro também são iniciativas individuais e é comum circular informações sobre como fazer. Sempre que há intensificação nos conflitos ou algum ataque mais violento os representantes organizam passeatas para chamar a atenção da população para pressionar por intervenções mais contundentes do Estado e para sensibilizar a população local para a versão palestina destes episódios.

A ideia de "nação palestina" é formulada, sobretudo, no confronto com as forças externas recorrentes no sentido de descaracterizá-los como nação. Nas contribuições apresentadas por Kanaaneh (2004) e Jean-Klein (2003), para a representação oficial palestina e seus agentes, o parentesco é investido de novas considerações sobre uma solidariedade, irmandade e companheirismo com apelo bastante significativo. As autoras concordam que há uma explícita politização dos processos domésticos cotidianos, como as visitas, as refeições e as celebrações de casamento durante a intifada palestina. Ambas consideram estes processos à luz do emergente estado-nação, e demonstram a produção de novos moral selves e de novas práticas de gênero e parentesco neste contexto.

Muitos exemplos relacionados a emergência de estados-nação e movimentos nacionalistas ajudam a perceber que a "nação" exerce um extraordinário apelo emocional sobre os cidadãos. No caso palestino, Kanaaneh (2004) demonstra que muitas práticas instituídas pela representação oficial palestina e seus agentes são apropriações das táticas israelenses de elaboração da nacionalidade. O caso israelense envolve discursos explícitos de biologização na ideologia da nacionalidade, de reprodução nacional ligada à reprodução biológica, iniciativas que acabam sendo reproduzidas pelos agentes públicos palestinos como reação à medida israelense. 
A utilização da linguagem do parentesco nesses casos não significa que a nação seria simplesmente o correspondente metafórico da família, pois o que se vê é de fato vivências que realizam estas disposições, e expressam de modo enfático o tipo de regulação da harmonia comunal. Como metáfora, esta imagem é evocada inconscientemente pelo poder estruturante de ações e experiência, em se transformando em realidade literal. Nas palavras de Carsten (2004),

[...] the power of the hackneyed metaphor of the nation as family rests partly with its very familiarity. As a 'metaphor we live by', it structures our experience of nationhood. But under extreme conditions, this metaphor can become a living actuality. And this slippage is a vital component of the force of kinship in the political realm (CARSTEN, 2004, p. 162).

Jane Carsten (2004) discorre de modo bastante conveniente sobre os processos de apropriação da linguagem do parentesco na produção de lealdades comunais e nacionais, pela transformação e criação de relações moldadas no idioma da natureza. Schneider (1977) já apontava para o fato de que os símbolos, o construído, constituintes do parentesco americano promoviam relações difusas ao mesmo tempo em que suportavam um tipo de solidariedade. As fronteiras, segundo o autor, entre os domínios do parentesco, da religião e da nacionalidade são turvas. 


\section{CAPÍTULO 3 - NA CASA}

As táticas de produção e reprodução social de parte da colônia palestina em Manaus têm nas práticas matrimoniais um mecanismo fundamental, que consiste na obediência a um preceito básico e explícito de casamento entre "árabes" em condições específicas, reconhecido como ideal para a constituição de uma família propriamente "árabe". Os mecanismos de sustentação destes valores, admitidos na escolha matrimonial, promovem efeitos de longa-duração, que se constroem nas expectativas de socialidade associadas a ideia de um lar muçulmano.

Os discursos revelam uma preocupação especial por parte dos homens em contrair matrimônio com mulher árabe, já que é geralmente aceito que à mulher cabe a educação dos filhos dentro do que consideram serem seus principais valores. Neste sentido, da mulher árabe se espera determinados comportamentos, definidos por um sistema de obrigações e responsabilidades no que diz respeito à conservação da honra. Quanto à escolha matrimonial por parte das mulheres da colônia, não há considerações a respeito da possibilidade de um lar muçulmano nas circunstâncias de um casamento com um homem brasileiro. As que assim procederam são apontadas como não tendo conseguido "salvar-se", uma vez que estão sob a autoridade do conjugue.

É importante frisar que as fronteiras entre "árabe" e "brasileiro" se tornavam frequentemente muito borradas, uma vez que estes indivíduos estão repensando ou dando sentido às suas práticas a partir também do repertório de representações com o qual convivem no Brasil, fato manifesto sempre que eu abordava o tema. Era comum que as pessoas argumentassem de forma a tentar me convencer, por exemplo, que a liberdade sexual, muito comum entre os jovens brasileiros, atenta contra a saúde além de ser moralmente degradante. Evocando as discussões sobre o sexo na forma dos tabus compartilhados por mentalidades conservadoras no Brasil, a retórica me parecia mais familiar ${ }^{13}$.

\footnotetext{
13 Na obra intitulada "Família, fofoca e honra: Etnografia das relações de gênero e violência em grupos populares", Claudia Fonseca faz uma conveniente reflexão acerca do "silêncio discursivo" no âmbito acadêmico sobre temáticas que privilegiem a compreensão de dinâmicas culturais populares. A autora sugere atribuir o fato ao atual clima de "euforia neoliberal" que tende a supervalorizar as implicações da modernidade, o que inviabiliza a identificação de práticas distintivas no interior de uma sociedade, localizando os grupos urbanos como "demasiadamente próximos de nós". Sem negar as indiscutíveis remodelações das redes de solidariedade e da vida associativa das classes populares no contexto da nova ordem global, Claudia Fonseca reitera que "para evitar que noções como 'cidadania' e 'sociedade plural' também se percam no palavrório dos chavões políticos, devemos recuar o suficiente para escrutar diferentes sistemas de simbolização no seio da sociedade moderna e reconhecer que, entre estes, o aspecto de classe não é de menor importância" (FONSECA, 2004, p. 228).
} 
Em torno do sexo, emergem muitos elementos fundamentais para a elaboração da ideia de "casamento árabe" um ciclo que se fecha quando o homem e a mulher são gestados dentro de condições que lhes propicia produzir e reproduzir conjuntamente uma mentalidade específica, criando uma família a partir da instituição do casamento. A decisão por esmiuçar os mecanismos de reprodução do que meus interlocutores chamam de "família árabe", é crucial para entender os meios pelos quais os homens responsáveis pela reprodução da empresa familiar conseguem mantê-la como tal, pois demonstro que os interesses relativos aos matrimônios geram ações que se conjugam com o espaço do mercado. Argumento que as ações comerciais dependem de uma certa configuração do espaço da casa.

Neste capítulo tento demonstrar que os discursos e as práticas no processo de produção da “família árabe" têm efeitos de produção da "colônia", na medida em que manifesta diacríticos de uma identidade social, que se entende como oposta à mentalidade ou às práticas que designam como "brasileiras". Além disso, como foi estabelecido ao longo desta dissertação, as relações entre os palestinos está sujeita a uma economia da dádiva, que explica os critérios de associação e dissensão nos negócios. Neste sentido, a criação da "família árabe" também representa um tipo de contrato entre palestinos que prevê a virtualidade do conflito na lógica desafio/resposta.

Segundo Bourdieu (1965), essa lógica está implícita na ideia de "honra" num caso etnográfico estudado pelo autor. Resgato este estudo para entender como as relações verificadas em campo contém as implicações do sentimento de honra, expressas nas aprovações e reprovações de ações e contratos, bem como em atitudes preventivas e restaurativas da afronta ou dano moral, que expressa como as partes envolvidas estão comprometidas com a moral de suas famílias, e que a família nova depende da reprodução desta moral. Nesta dinâmica, identifico alguns valores em jogo e desenvolvo a noção de "honra", pois marca muitas vezes os discursos de meus interlocutores em suas definições de casamento e família.

\subsection{Algumas considerações sobre honra}

Em uma interessante revisão das principais obras constituintes da Antropologia do Mediterrâneo (que inclui a Península Ibérica, Sul da Europa, os antigos Estados socialistas do Leste da Europa, países do Oriente Médio e do Norte da África) que tratam do tema da "honra" e da "patronagem", Ana Marques (1999) constata que tais conceitos têm funcionado como os valores culturais que forneceriam o nexo conformador de coletividades e de condutas individuais. Neste trabalho, a autora reúne as principais críticas ao que se 
convencionou chamar por esses termos, principalmente pelo consequente esvaziamento semântico resultado das indeterminações, ambiguidades e multiplicidades semânticas envolvidas na vida social. Para a autora,

a confusão entre construções analíticas e nativas congela, portanto, toda uma dimensão retórica. É como se perdêssemos de vista o caráter "dissêmico" dos símbolos, a oposição entre o que os atores sociais mostram de si para os outros e o que sabem de si mesmos — pólos que se alimentam mutuamente. Oposição que não é entre ideal e real, mas do uso de estereótipos de formas e com finalidades distintas (MARQUES, 1999, p. 138).

A crítica se afina à proposta de Bourdieu (1960), quando constrói reflexões mais céticas a respeito das formas estereotipadas que a cultura pode apresentar. $\mathrm{O}$ sentido da honra na sociedade Cabila, por exemplo, se expressa sobretudo a partir da lógica do jogo desafio/resposta enquanto um momento de troca, fundamentado na pressão da opinião pública. Neste caso, a ofensa que desafia a honra e requer uma reparação, é como o dom que requer uma retribuição. Portanto, assim como a troca, a lógica do desafio/resposta também é portadora da virtualidade do conflito, em que a gravidade do desafio bem como a modalidade de sua reparação são explicadas no contexto de uma teoria da reprodução:

\footnotetext{
Aquilo a que se chama o sentimento de honra não é mais que a disposição cultivada, o habitus, que permite a cada agente engendrar, a partir de um pequeno número de princípios implícitos, todos os comportamentos em conformidade com as regras da lógica do desafio e da resposta, e só esses comportamentos, graças a outras tantas invenções que o desenrolar-se estereotipado de um ritual de modo nenhum exigiria" [...] Isso quer dizer, em outras palavras, que um comportamento nunca é perfeitamente previsível. (BOURDIEU, 1965, p. 22)
}

Entre os Cabila, a honra pode ser representada pela parte suscetível de ser ultrajada, de modo que a manutenção da honorabilidade e pureza da linhagem representa mais deveres do que os privilégios em si. O autor apresenta duas dimensões do que corresponderia à suscetibilidade Cabila: o sagrado esquerdo e o sagrado direito, que manifestam a distinção marcada entre o feminino e o masculino, respectivamente. No bojo desta distinção, existem diferentes oposições proporcionais, como a oposição entre a sexualidade feminina, culpada e vergonhosa, e a virilidade masculina; a casa e seu quintal, lugar secreto e protegido, se opõe ao lugar das assembleias, à mesquita, ao mercado e aos campos.

Sobre as práticas matrimoniais do campesinato de Bearn, na França, Bourdieu afronta a teoria paradigmática de Lévi-Strauss, explícita na assunção de que práticas consideradas endogâmicas, como o casamento com a prima paralela, são a negação da aliança e, portanto, uma expressão da negação do casamento. Para tanto, a análise de 
Bourdieu propõe uma mudança do enfoque analítico que sai das estruturas elementares para as práticas matrimoniais entendidas dentro de um contexto de reprodução social (WOORTMANN, 2004).

A unidade do parentesco em Bearn, a maison, também corresponde à casa no sentido empregado por Lévi-Strauss, e tem um forte viés patrilinear e um padrão de herança caracterizado pela unigenitura. Mas as práticas matrimoniais em Bearn demonstram que a lógica de casamento entre primos paralelos responde a um princípio de preservação da casa e da honra. Neste sentido, para o autor o casamento visa reproduzir a casa, mobilizando estratégias com relação aos primogênitos e demais filhos e filhas. Dito isto, o arranjo matrimonial entre primos paralelos seria inconcebível na concepção clássica, uma vez que não viabilizaria a reprodução social que supostamente se realiza apenas por um comportamento exógeno.

O ponto problemático, e que o caso apresentado por Bourdieu ajuda a peceber, é que os pressupostos que definem "exogamia" e "endogamia" se definem por concepções de consaguinidade e afinidade muito restritas, um ponto discutido por autores como Schneider (1965). Este autor é crítico ao pressuposto de que as unidades fundamentais de parentesco são sempre as relações genealógicas; isso pressuporia a universalidade destas redes. A sua crítica versa, sobretudo, contra a suposição clássica de que a criação da descendência humana - por meio do intercurso sexual - constitui o processo biológico sobre o qual a cultura constrói relações sociais, como o matrimônio e a filiação.

Para Schneider, a reprodução humana nunca é apenas uma questão de concepção e nascimento. As pessoas são produzidas de outras formas, são produzidas socialmente. Neste sentido, a produção da "família camponesa em Bearn" seria um esforço de reprodução da "casa" através de outros mecanismos que não os processos biológicos, necessariamente. De modo a viabilizar alianças dentro de uma exigência de consubstancialidade, os padrões de consanguinidade e afinidade assumem contornos que confundem as definições clássicas dos estudos de parentesco.

Isto porque, como explica Bourdieu (s/d), a família não possui nenhum sentido em si senão o fato de constituir-se como um princípio cognitivo e afetivo de adesão a um grupo, possuindo as características de um campo, com seus mecanismos de coerção, conservação e transformação. Em função do lugar que as categorias familiares ocupam no mundo, ela pode prescrever um modo de existência que pode figurar como o principal dentro das estratégias de reprodução. Neste sentido, a ideia de "família" implica um sistema de apreensão e construção do mundo, com meios materiais e simbólicos específicos de sua conformação lógica e moral, produzidos e reproduzidos pelas pessoas e pelo Estado. 
É na interseção entre as diferentes escalas de processos de subjetivação que se encontram misturados os princípios de ficcionalização da família, de sua existência enquanto um artefato social "bem fundamentado" nas práticas e discursos individuais e coletivos. Inspirada nestes princípios, pretendo oferecer um quadro das práticas matrimoniais e das construções de gênero na colônia palestina de Manaus a partir dos discursos e movimentos acompanhados em campo. Neste exercício reconheço que as reflexões em torno da ideia de honra se fazem fundamentais, não como uma regra formal e rígida, mas como um valor que prescreve relações desejadas e contribuem para a reprodução de uma espécie de "casa", a instituição pelas quais se dividem nomes, linhagens e patrimônios.

\subsection{Um segundo caso exemplar}

Para alcançar as definições em torno da honra, recorro a um evento etnográfico que reúne alguns dos principais interlocutores desta pesquisa. $\mathrm{O}$ evento se deu nas circunstâncias de um encontro combinado entre eu e Graça, mas que contou também com a sua irmã Carmen e parte de suas famílias. Na oportunidade, as implicações da ideia de honra ficaram bem evidentes, embora eu reconheça que este tema foi acionado em outros momentos em campo. Mas o modo como esta ideia foi utilizada faz deste caso um caso exemplar das estratégias de construção de gênero, pronunciadas a partir do "casamento árabe", que foi o interesse utilizado por mim para propor o encontro.

Faz-se necessário lembrar que este diálogo ocupa posição parcial para o tema tratado, pois depende da posição ocupada pelos sujeitos que o elaboram. Contudo, sugiro que os sentidos explicitados aqui podem revelar dissenções internas quanto aos valores evocados na colônia como um todo. Isto se dá porque a posição do diálogo dos atores a partir dos quais minhas análises são construídas é subalterno, com pouco poder normativo. O grupo não é reconhecido para as questões públicas da colônia, e tampouco controla os principais fluxos engendrados em nome desta. Contudo, este grupo demonstra evidentes sinais de que as forças que geram autoridades e valores dominantes são negociadas e, de certa forma, independem das posições econômicas e políticas que os sujeitos ocupam.

Depois de algumas conversas com a dona Graça, criei coragem para introduzir os assuntos que eu julgava mais pertinentes à pesquisa, justamente os que me causavam desconforto em campo. Seja pela minha interferência ou pelo próprio modo como estes temas 
circulam no Brasil, o fato é que são polêmicos, pois evocam estereótipos e outros "escândalos" que costumam marcar "diferenças culturais" e sugerir reprovações. Obviamente, ela também percebia a gravidade dos efeitos possíveis de sua palavra registrada, e disso não se esquecia.

Por telefone, perguntei se ela não estava disposta a me conceder algumas horas para conversarmos sobre o "casamento árabe". Ela acedeu ao pedido, sempre generosa. Arrisco a dizer que ocasiões como a da minha visita requerem um almoço, pois novamente ela unia a conversa à refeição com sua família, quando se comprazia em me ver comer (e muito!) as suas receitas. Desta vez, o almoço seria na casa da irmã, também casada com um palestino.

Cheguei um pouco mais tarde do que o previsto para acompanhá-la na cozinha, mas a tempo de encontrar o movimento frenético das mulheres nos últimos preparativos do passeio que já beirava o início. Foi-me permitida a entrada na casa, já sem cerimônia. Passei pela garagem rumo à entrada pelo quintal, de onde se vê as raízes grossas das árvores e a sombra fria das folhagens deitando no espaço em transformação, invadindo o oco da piscina que agora contém pedaços do mobiliário enferrujado da antiga loja de confecções.

Dona Graça me saudava de longe. Andava pra lá e pra cá, reclamando estar toda suja. A camisa era respingada de temperos, os cabelos escorriam à altura dos ombros, lisos e escuros, sacudindo no rosto moreno e muito redondo que não lhe negava a origem. Os braços grossos agitavam à cada diligência dada aos netos e noras ainda vacilantes nestes assuntos. Oi Bárbara! Saudavam-me os seus. A makluba já estava pronta, o bolo de chocolate ainda teria que continuar assando, mas fomos assim mesmo, pois seu filho já aguardava impaciente no carro que nos levaria à casa da dona Carmem, onde almoçaríamos juntos.

O bairro de dona Carmem é bem próximo ao da dona Graça, e faz limite com o rio Negro, cujo ritmo plácido pode ser avistado dos pontos mais altos. As ruas estreitas e tortuosas são incrustradas de sobrados irregulares e contíguos, poucas praças e alguns campos de futebol. A casa fica no segundo andar, o primeiro, diz-se, é de um irmão delas. Este seria meu primeiro contato mais intenso com a anfitriã, que não havia dado margens para conversas como aquela em outras ocasiões.

Dona Carmem não havia sido avisada da minha presença, mas apesar do pequeno mal estar que isso causou, aquele encontro teve um efeito positivo, de modo que pudemos desenvolver uma relação muito profícua, das mais voluntárias em campo. O almoço foi servido e fartamente compartilhado pelas duas famílias, no ambiente simples mas muito acolhedor de sua residência, e foi seguido de uma conversa conjunta, proposta pela dona Graça, sobre o tema que havíamos combinado. Todos ouviam as suas colocações, as de dona 
Carmem e as de seu filho, emitindo suas opiniões, rusgas, risos e outras emoções. Dona Carmem, tendo vivido por 27 anos entre a Arábia Saudita, a Palestina e a Jordânia, sabe de muita coisa. A sua sogra, por exemplo, foi roubada!

- Não acredito, Carmem! Disso eu não sei não! - Falou dona Graça com invencível surpresa e animação.

- É sim, geralmente quando chegava o cara, que ele via uma moça lá, ele roubava ela. Mas na hora mesmo ele mandava pra casa de alguém importante, vamos dizer assim, como se fosse o sheer da aldeia, sabe? Então, ela ficava lá na casa desse sheer.

- Ahhh! Por isso que antigamente tinha a história do cavalo né? Que a moça era levada num cavalo né? Ai, conta que essa história é bonita! Olha Bárbara! Nem eu sabia disso! - E comemorou muito feliz a novidade.

- Mas eles se combinavam antes, perto da nascente de água.

Era o filho de Dona Carmem que interferia, o Ryan, rapaz de uns trinta anos, sempre combatia os efeitos fantásticos das palavras da mãe e da tia. Ele era lógico e contextual. A nascente de água, ou o poço, eram no mais das vezes frequentados pelas mulheres, que abasteciam os grandes jarros de cerâmica com o líquido para o consumo doméstico. Nenhum homem podia se aproximar nesses momentos. Mas foi ali que o encontro se deu. O casal prosseguia nos encontros mesmo sabendo do perigo que estavam correndo, pois se os pais da moça detectassem algum sinal que lhes ameaçasse a honra, o caso poderia ter um desfecho cruel. Mas dona Carmem continua:

- Mas essa história é dos beduínos antigos, porque cada região é uma cultura. Porque é assim, quando o homem sabe que a família da moça não ia aceitar esse pedido, ele roubava ela. A minha sogra, ela foi pedida, só que não deram, aí o meu sogro foi lá e roubou ela.

- Acontecia assim - Interveio Ryan - Pra não ficar feio pra família, pra não desonrar a família, eles acabavam aceitando. 
- Mas por isso que antes o homem levava ela imediatamente pra uma família poderosa, que nem o sheer, porque assim a família vai ficar sabendo que ela tá bem.

Sob a custódia de uma autoridade como o sheer, a nubente salvaguardava sua honra e, consequentemente, a honra da família, enquanto esperava o desenrolar dos acontecimentos. Esse caso revela uma situação delicada em que a honra da família é desafiada, porque o único expediente encontrado pelo noivo interessado em contrair um matrimônio proibido era o de tirar a moça da guarda dos pais, e levá-la para a casa de alguém cuja moral fosse respeitada. Assim, o noivo conseguia forçar o casamento, já que provara que já houvera tido contato com a moça. Embora tendo a garantia dos cuidados do sheer, a honra está ameaçada pela probabilidade de os noivos cometerem alguma ofensa irreversível, de modo que a sua família se via forçada a responder ao ultraje aceitando o enlace.

- Mas a minha sogra foi porque quis, ela não foi forçada não! - Protestou Dona Carmem - E ele devia amar muito ela!

- Mas hoje em dia - Continuou, Ryan - Eles vão em nome da família, quando sabem que os pais da moça são uma família de boa índole entendeu? Que não tem passado ruim, não tem essas coisas assim. Geralmente quem vai atrás pra procurar saber essas coisas é a mãe do homem ou uma tia, elas vão ver a menina primeiro, chegam lá e dizem que querem ver a filha. Se elas gostarem, aí marcam outro dia, quando o homem interessado vai junto. Chegando na casa da menina, ela vai servir o café pro rapaz, aí ele vê. Se ele gostar então eles podem conversar. Mas sem tocar, ele só pode tocar nela depois do casamento.

- Mas é melhor que seja entre primos. Vou te dizer porquê. Porque tem a segurança da família, porque a família sabe que ela vai casar com um rapaz que vai honrar ela, que vai cuidar dela, que não vai maltratar ela - Completou dona Carmem.

- É. Porque eles já sabem, já conhece a história dele. Mas aqui, ainda tem a questão dos negócios, de querer manter o patrimônio - Disse Ryan, se referindo aos palestinos de Beni Naim que moram em Manaus. 
O fato de os palestinos se referirem como "primos", não significa que escolheriam qualquer um dos "primos" de Manaus para as trocas matrimoniais. Assim, o grupo foi enfático em resposta à minha provocação: “De jeito nenhum!” Bradaram os três e outros tantos - "Mas eu já te disse, eles são tudo fallah, uma raça ruim, ignorante!", desabafou Ryan, provocando um riso geral. Entre estes interlocutores, são muitas as referências negativas aos provenientes de Beni Naim, mas tais aspectos são mais bem entendidos quando as pessoas que fazem estas observações estabelecem comparações, e os pontos destacados para demonstrar isso variam basicamente em dois aspectos. Ryan, por exemplo, quis se referir ao fato de que estes palestinos evitam relações mais íntimas com o restante da colônia, são egoístas e alimentam algum tipo de preconceito em relação às famílias mais simples. Ryan se refere sobretudo aos palestinos mais ricos que possuem comércio na Marechal.

A sua mãe, dona Carmem, quer se referir à liberdade excessiva de que a juventude de Beni Naim aparenta gozar em contraste com a juventude da vila de seu marido, que é a sua referência para a moralidade correta e o costume rígido. Segundo Carmem, isto se revela na liberdade de se locomover das moças, nos trajes que vestem quando estão entre mulheres, e na arrogância, ou "falta de educação" que a população local manifesta quando se confronta com turistas ou visitantes. Isto ocorre, por exemplo, quando alguma mulher chega com os cabelos descobertos, e são reprovadas ou agredidas verbalmente por algumas mulheres de Beni Naim.

Nasser é o esposo de Carmem, e decidiu morar num país árabe (Arábia Saudita, Palestina e Jordânia respectivamente), depois que começaram a nascer apenas filhas mulheres. Nasser disse que não podia criá-las no Brasil, e escolheu um lugar onde julgava poder gestálas dentro de uma subjetividade árabe e muçulmana. Apenas depois nasceram os filhos homens, e mais tarde, Nasser decidiu voltar com a família para o Brasil onde investiria o dinheiro conseguido nos trabalhos na Arábia Saudita. Todas as suas filhas são casadas com homens de Beni Naim, e atenderam as formalidades relatadas para o noivado e o casamento. O esposo da filha mais velha, um dos irmãos de Omar, não apareceu nenhuma vez mais na casa do sogro depois de esposá-la, segundo Ryan, sendo que o mesmo havia visitado os pais da noiva todos os dias durante o ano do noivado. Em geral, a escolha da noiva e do noivo é antecedida pela escolha e aprovação da família, de seus pais, tios, tias e irmãos, havendo um agenciamento especial por parte das mulheres, no sentido de procurar e avaliar os pretendentes. Foi nesse sentido que dona Graça introduziu o seu caso e o de sua irmã: 
- E quando eu me casei com o meu marido foi o maior trabalho. Porque eles não aceitavam mulher brasileira, queriam mandar buscar mulher de lá pra casar com ele. E a luta foi muito grande porque foi ele que lutou, porque quando ele me conheceu, acho que ele me amou de verdade porque pra lutar como ele lutou, pra ficar comigo, foi muito trabalho. Porque ninguém queria, eles queriam que ele casasse com uma mulher de lá. Mas hoje em dia todos eles gostam de mim, falam comigo. Mas isso aí é preciso a gente conquistar, foi dois anos.

O meu marido conhecia o Nasser. E ele ia muito pra minha casa. $\mathrm{O}$ meu marido era todo grosseiro, quando ele chegava em casa ele jogava as coisas pra cima de mim e eu ficava lesa lesa, ficava sorrindo, e o Nasser achou aquilo legal e me perguntou se eu não tinha uma irmã. Eu disse que eu tinha mas que ela ainda era muito nova, tinha só quatorze anos naquela época. Mas ele não quis saber, disse que queria casar com ela. Aí o meu pai quase que obrigou ela a casar.

- Mas pode casar com quatorze anos?? O pai pode obrigar a filha a casar??

Foi Halimah, sua neta de 12 anos, quem não disfarçou o espanto. A menina estava prestes a menstruar, e já estava sendo orientada a respeito do véu. Isto era o anúncio de que seguiria os passos da irmã, que há alguns anos havia ido a Palestina para conviver com a família do pai, e se preparar para o casamento que se deu alguns meses antes desta conversa. Desde então, Halimah nunca mais a vira, e não se continha de saudade e apreensão pela mudança que se daria em sua vida, num futuro bem próximo. "Só vou se a mamãe ficar comigo lá!” Foi o que respondeu quando perguntei se ela estava feliz com a viagem. Neste dia, a menina perambulava com o que parecia um grande lençol de algodão florido ajustado na cabeça, que caía até a cintura deixando o rosto à mostra. "Isso é pra eu ir me acostumando". Disse a menina meio envergonhada, antes de descer correndo pelas escadas, fugindo do revide de um tabefe que havia acertado no primo.

Segundo alguns interlocutores, a relação entre as famílias palestinas nas primeiras décadas em Manaus era muito mais intensa. As decisões de ir e vir eram tomadas em conjunto, bem como as deliberações sobre o destino do homem recém-chegado, com relação ao seu trabalho e constituição de família. Aliás, qualquer vinda era programada e controlada pelos homens, dentre os quais se destacava Farid, pelo seu tino para o comércio e bons conselhos referentes à vida familiar e coletiva. Mesmo não tendo casado com uma palestina, Farid e vários homens escolhiam filhas de sírios e libaneses com os quais laboravam no 
comércio, o que para eles era mais aceitável do que as filhas de casais brasileiros. Isto evidencia que o lar é um forte determinante da personalidade dos sujeitos, mas parte dessa personalidade pode ser reconhecida mesmo entre jovens sem relação com o repertório árabe ou muçulmano, que foi como Graça e Carmem apareceram aos olhos dos maridos.

- Cala a boca Halimah! Não fica perguntando não, não se meta não! - Reprovou a avó.

- Mas tem que perguntar - Respondeu a menina, sem jeito, enquanto dona Carmem procurou esclarecer o comportamento do marido:

- O meu marido, o nosso costume é rígido. O Beni Naim já é liberal, assim, em todos os sentidos, eles são fallah, que quer dizer "muito liberal".

- Tu acha liberal? - Perguntou dona Graça, cética.

- Na frente do meu marido é - Respondeu a irmã, arrancando risos de todos.

Mas dona Graça gostava de falar das coisas do céu, e um bom exemplo da conquista dos valores islâmicos é a sua própria vida. Os três anos que passou morando na Palestina lhe proporcionaram uma fé sem igual, e um dom de falar das lições do Profeta, do Livro Sagrado. Os anos na terra lhe conferiam a serenidade e a autoconfiança própria dos que veem a si e a Deus, antes de tudo. Com essa postura Graça conquistou o reconhecimento da colônia que a percebe como dedicada cumpridora da moral islâmica. Esposa e mãe resignada, as relações de Graça com os filhos demonstram muita paciência e tolerância para com as diferenças de gênero:

- Porque lá a gente vive com um tomate e um pedaço de pão, e o importante é que você viva diante de Deus. Fazendo as coisas boas. Ajudando as pessoas que precisam, entendeu? Uma coisa que eu senti, quando eu morava lá, eu não gostava de falar com brasileira. Porque brasileira lá era muito revoltada, elas não procuram a cultura, elas não procuram a religião, então elas são assim, sofridas, sofridas pela família do marido, pelo marido, então eu não gostava de falar com brasileira porque elas eram revoltadas. E eu não. Porque eu me dediquei à família do meu marido, à nossa religião, entendeu? Eu procurei a 
religião. Se lá, tu vai pra lá e age da maneira deles, ainda há diferença, mas eles aceitam. Mas eu fui aceita assim, porque eu era religiosa, muito religiosa, fui pra lá pra aprender a religião, pra procurar, buscar, que nem uma criança, lutando, pra mim conseguir chegar nisso, porque eu não sabia falar nada, completamente nada, e lá eu, por meu esforço eu lutei. E tem muitas pessoas que te dão muito valor, mas tem muitas que te desclassificam, mas eu sempre procurei andar na minha religião, e no costume árabe, no costume deles. Sempre tem uma barreira. Embora tu ande na religião, tu seja muçulmano, tu fale árabe, tu ande no costume árabe, mas tem uma barreira.

- Se alguém chegar comigo e me oferecer o estado brasileiro em troca de um palmo de terra na Jordânia, eu prefiro o palmo de terra na Jordânia. Porque eu prefiro dar educação pro meu filho lá. Por mais que a gente tenha a liberdade aqui, até em função de trabalho que é melhor aqui do que lá, mas eu prefiro morar lá do que aqui. Eu prefiro dar criação pro meu filho lá do que aqui - Declarou o sobrinho.

- Existe muita solidariedade lá. Eu morei num bairro excelente em Aman, na Jordânia. Recebi muita ajuda, não por parte dos parentes, mas eu fiz muita amizade lá. Se eu chegar lá todo mundo gosta de mim, todo mundo me conhece.

- Aqui com os Beni Naim daqui não existe não, cada um que se lasque. Deus por si e o diabo pelos outros! - Desabafou dona Carmem.

- A gente diz assim, mas porquê? O Deus de lá é um e o daqui é outro? Mas não, é só um Deus, mas o povo é diferente. Eles se tornam brasileiros assim, eles se tornam do dinheiro, do poder. Aí eles não têm aquela irmandade, aquele coração bom, de tu chegar, por exemplo, tu é muçulmana, se tu chegar com uma pessoa que ela precisa, aquele muçulmano tem obrigação de dar moradia pra ti, de te ajudar, te dar dinheiro, se ele tem ele tem que te ajudar. E aqui eles não têm isso. Mas eu casei muito nova, nós casamos muito novas, eu com dezoito e ela com quinze. Então a diferença é grande, depois que você vai se acostumando. Porque a gente vem de uma criação diferente, aí quando você chega com o homem lá, ele diz, quando ele briga contigo: “cadê, o que foi que tu trouxe da casa da tua mãe?" Eu não trouxe nada, isso aqui tudo é dele, é da família dele, dos irmãos, é dos pais, da família toda, e ele trazia muito irmão, trazia muito sobrinho, a casa todo tempo era cheia. 
O relato produziu um sentimento de pesar. Todos permaneceram pensativos pelo tom grave com que falara Dona Graça. Em mim, várias coisas reverberavam de suas palavras ao mesmo tempo que eu tentava perceber se eu compartilhava das mesmas impressões que os demais ouvintes. Dona Graça verbalizou algo que eu já havia notado, mas que falado daquele modo e com aquela franqueza causavam até tristeza e revolta. Em quais momentos eu verificaria aquela irmandade que adorna as falas que promovem a "colônia"? Entre quais famílias e para quais fins eu encontraria a solidariedade apregoada e a concorrência saudável? Por quê aquela família se sentia desprezada? Por vezes em campo eu me perguntava o porquê de a assistência entre as famílias ter tido fim, já que essa coesão é indiscutível na retrospectiva destes interlocutores.

Além disso, dona Graça era muito jovem quando começou a ter que suportar estas questões interferindo na vida familiar, e parecia não ter previsto o tipo de regime matrimonial ao qual estava aderindo. Certa vez, presenciei ela aconselhando Carmem que se queixava da inflexibilidade do marido, dizendo que se ela se divorciasse não ficaria com nada e, portanto, era mais sensato que suportasse tudo. Olhando por este lado, aquele testemunho podia ter um efeito encorajador para os casos em que "suportar" significa "não desistir". Mas foi ela quem quebrou o silêncio, tentando voltar para o contexto rígido de formação do cunhado, e perguntou denotando interesse em anunciar as histórias de lá:

- Agora conta aí a história da menina, que mataram ela.

- Ahh, ela tava cuidando dos carneiros, e um rapaz mexeu com ela, aí depois de um tempo mataram ela e mataram ele, porque o rapaz mexeu com a moça - Respondeu a irmã;

- Se foi o rapaz que mexeu com a moça porque mataram ela?? - Retrucou Halimah indignada.

- Porque lá é assim. Quando a pessoa perde a honra, matam. Essa história saiu no jornal, todo mundo sabe. Tem vários casos. Tem um que o rapaz mexeu com a moça, tirou a virgindade da menina, aí depois descobriram porque ela contou pra mãe dela, e então o próprio pai matou ela. Esses casos raros lá, se aqui acontece 40 ou 50 vezes, lá acontece a cada 5 ou 10 anos (em Aman, na Jordânia). 
- E o cara quando é assim, é condenado à morte em praça pública, pra todo mundo ver, pra ficar de exemplo. Isso se a polícia não pegar antes, mas a polícia nem se mete (a polícia da Jordânia), ela já sabe do costume árabe - Completou o filho.

- Mas vamos falar de coisa alegre, porque essa parte não é legal - Sugeriu Carmem.

- Então, continua a falar de como eles são diferentes - Dessa vez fui eu tentando recuperar a ideia, no que Carmem continuou:

- É que cada cultura é diferente. Em Ramallah, por exemplo, a gente é chique e muito pra frente, são mais sofisticados. Mas o árabe é assim, por exemplo, uma pessoa do interior, é inteligente, são estudados, tem diploma, só que eles não perdem o costume deles, não querem mudar.

- Mas fala aí que o pai vai pedir a moça, e que são três dias de festa - Interferiu Dona Graça fazendo a solicitação ao sobrinho que respondeu:

- Ahh, sim mas é muita coisa. Então, após servir o café, a noiva é quem serve o café, e se a família do homem gostar, vão marcar uma visita na casa da noiva, nesse encontro só vai a família do noivo. Geralmente vão as tias, que são mais enxeridas, a mãe e o pai, e eles marcam pra tomar café, aí já pedem a noiva oficialmente. E é um homem, o chefe da família do noivo, alguém que tem nome, que vai pedir a noiva. Nisso, eles põem uma xícara de café na frente do pai da noiva e uma na frente do representante do noivo, se o pai da noiva aceita tomar o café, ele diz sim para o noivado. Geralmente no ato do noivado acontece o casamento civil, celebrado pelo xeique, perante a lei, eles são casados, mas até a festa do casamento o homem não pode tocar na noiva. Nesse intervalo entre o noivado e o casamento, o noivo pode visitar a noiva todos os dias. A saída da noiva da casa dos pais é a parte mais celebrada, vai um comboio que acompanha a noiva até a nova casa, a casa do noivo, os homens cantando, cantando.

- Não, mas quando eu fui levar meu filho né, aí ele casou tudinho, fez a festa né... Começou Dona Graça, logo interrompida pela irmã:

- Ahh mas isso não existe mais hoje, mais entre os atrasados. 
- Existe sim. Aí tem uma casa do meu sobrinho, que deixou a casa dele com a mulher dele, e arrumaram todinha. Coloca assim um colchão no chão, entendeu? E forra bem direitinho, pra deixar a noiva e o noivo. Aí a mãe dela mandou ela tomar banho e se limpar e rezar, e depois veio o marido, mandou ele tomar banho...

- É porque se purifica - Completou a irmã.

- Então, mandou ele fazer duas rezas, a ablução, aí depois a gente saiu de lá e deixou (risos). Aí a gente disse "assim que fizer, tu apita que tu já fez, que tu já tirou!”. Aí nós ficamos na casa de cima, era frio, frio, frio, sabe? Ai tem um pano branco que a gente coloca que é pra quando sair o sangue da moça, pra ela mostrar pra mãe, pra família que ela era virgem. Aí todo mundo foi pra lá e foi aquela risada!

Nesse momento a conversa seguia descontraída. No lugar ainda havia duas mulheres brasileiras casadas, dentre elas a esposa de Ryan, e uma palestina com poucos anos de casada, nora de Dona Graça. Todos acompanhavam atentos, emitiam risos e sinais de desaprovação. A nora de Dona Graça estava toda encolhida num canto, com um sorriso tímido na face rubra de vergonha pelo caso que também era o seu. A descontração era geral, só Halimah que parecia estremecer com a imagem descrita pela avó. Com exceção das brasileiras que torciam o nariz, os demais viam pertinência no ritual do casamento árabe. Parecia que se tratava da união entre a inocência da mulher virgem com a virtuosidade do homem viril.

- Mas sim! - Atravessou Ryan - O que mais queres saber? Das quatro mulheres?

- Mas sim, pode casar com quatro mulheres sim - Respondeu a sua mãe antes que eu devolvesse a ironia. Mas foi Dona Graça que esclareceu, em tom professoral:

- Se o homem casa com uma esposa que não faz filho, que não traz felicidade pra ele, porque não tem prostituta pra ele procurar na rua lá. Então a mulher dele, tá vendo que ela tá doente e não traz bebê, ou traz só menina, e ele quer um homem, entendeu? Aí ela vai procurar uma mulher pra casar com ele. Ela, a esposa dele, procura uma mulher pra casar com ele. E se ele tiver muito dinheiro, ele precisa gastar, ele precisa expandir, aí vai casando até chegar a quarta vez, entendeu? Mas tem que ser tudo combinado com a mulher, 
com as mulheres dele. A maioria dos árabes que está no Brasil, eles têm outra mulher brasileira. Tem uma lá e outra aqui. E as mulheres árabes, teve uma que até desmaiou quando soube. Mas os homens árabes eles têm aquele costume de casar com uma esposa árabe, pra trazer alegria pra família.

- É mais pra criação dos filhos - Contestou o sobrinho.

- É pelos filhos, pra seguir a religião. Eu pelo menos, fiz questão de casar meus filhos com mulher árabe pra seguir o costume, porque se eu fosse deixar eles casarem tudo com mulher brasileira eles não iam ter o costume, a religião muçulmana que predomina. Os filhos já de pequeno eles já vão ensinando. Só que eles casam, eles têm família, mas eles vêm e deixam a família lá. E tu já pensou um homem sozinho no Brasil onde tem muitas mulheres? E ele precisa de mulher, aí ele pega e casa com uma mulher brasileira pra ele ficar bem, pra não ficar pecando diante de Deus. Porque quando tu tá com uma moça sem ser casado tu tá na prostituição, se a pessoa é casada com uma mulher e ele não tá casado diante de Deus ele tá no pecado, então esse é o pecado. É a coisa que eles têm na cabeça deles que eles têm que casar, pra eles terem uma mulher certa lá, e aqui uma mulher outra que ele vai andar, por causa que ele precisa né? Aí ele constrói uma família com essa mulher daqui, e essa mulher as vezes se torna muçulmana e as vezes não, as vezes ela continua na religião dos pais, da família dela, entendeu? Também o homem árabe ele não obriga não, tá? Cada uma pessoa segue a religião que quer, eu escolhi a religião muçulmana porque eu quis, pelo meu marido eu usava era shortinho curtinho que ele não tava nem aí.

Nesse momento Dona Graça contava sobre como se dá o uso do véu entre as mulheres. Para ela, os pais muçulmanos não devem obrigá-las a portar o véu, pois esta deve ser uma iniciativa própria e sincera, ainda que as coerções se deem implicitamente na convivência diária. É importante incluir aqui uma conversa que tive com Ranya a respeito do véu. Esta interlocutora conta que enquanto morava em Ramallah não foi habituada a usar o véu, e mesmo depois de casada não internalizou o hábito. Ranya conta que quando chegou em Manaus, há 15 anos atrás, a maioria das mulheres palestinas não usavam o véu porque alegavam que seus maridos sentiam vergonha de exibi-las vestidas com rigor, ou seja, com roupas que não marcassem as silhuetas do corpo e que escondiam os cabelos. 
Atualmente, Ranya condena tal comportamento pois acredita que a conversão sincera também depende do uso adequado das vestes, e que essa deve ser uma condição para a adequada relação entre si e Deus, que está acima daqueles constrangimentos. O uso do véu se configura como um aceite profundo da religião entre estes interlocutores, uma declaração pública e notória da identidade religiosa. Mas não somente, trata-se de uma "preservação", cuja origem se encontra na ocultação do corpo, receptáculo da honra, e que permite que a mulher transite em ambientes com a presença de estranhos. Como colocou Ryan:

- Essa questão de se preservar, isso é bem antes do Islã. Porque antes do Islã chegar, o povo que morava na Arábia Saudita, quando eles casavam e tinham uma filha mulher, eles enterravam viva, porque um dia ela ia trazer decepção pro pai. Aí as vezes a mãe fugia, porque é mãe né? Mas se o pai pegava, ele enterrava a menina viva. Aí chegou o islã e proibiu isso.

- Desceu a Sura no Alcorão Sagrado, que o pai não podia mais fazer isso com as crianças, enterrar as meninas vivas - Completou Graça.

Então ela contou sobre como o Profeta recebia as Suras, os capítulos do Alcorão, e demonstrou a sua maneira de apreender a pertinência do Livro Sagrado para regular os comportamentos as pessoas:

- Era o anjo Gabriel que vinha pra ele. E depois o Profeta se dirigia para os amigos dele que eram muitos. Eles decoravam tudo o que o Profeta falava, tinham tudo de cabeça, e depois eles escreveram as mensagens nas folhas e onde podia porque na época não tinha papel. E depois virou o Alcorão Sagrado, que nunca mudou. Diferente da Bíblia que já mudou muitas vezes, por causa dos reis que queriam comandar o palácio deles, e com alguma lei eles aumentavam na Bíblia. Por isso que eles falam que Jesus é o filho de Deus, sabe?

Dona Graça emendou na pregação enquanto tomávamos chá preto e comíamos bolo. Este diálogo pareceu-me o mais profícuo para demonstrar alguns dos elementos combinados nas dinâmicas diárias de gestação de uma subjetividade palestina. A família em questão não figura nas instâncias de representação e nem é responsável pelo controle dos fluxos coletivos entre Manaus e Palestina. No entanto, estas pessoas reivindicam uma 
“palestinidade", elas “são" palestinas, e não apenas "se sentem" palestinas no sentido das identificações políticas. Ainda que Graça e Carmem não se sintam reconhecidas como tais, elas se orgulham do mérito conquistado de ter possibilitado o cultivo das características exigidas pela colônia.

Alguns princípios emergem das situações descritas. Em primeiro lugar, o de que o ambiente da casa é um forte determinante da personalidade dos sujeitos. A formação de pessoas com as características exigidas começa com a educação no lar, onde as disposições são inculcadas nas mentes dos novos sujeitos. Estes interlocutores demonstram o quanto a mulher está associada à reprodução do costume, cabendo fortemente à ela a tarefa de performar a cultura no âmbito da casa, enquanto é apenas coadjuvante no espaço do mercado ou nas performances culturais públicas onde o papel do homem impera. Mas como será exemplificado na próxima seção, apesar dessa importância, a mulher "não é ouvida pelos homens" como expressa Ranya, de modo que pode ter sua influência anulada até pelos filhos homens e sua opinião desconsiderada no espaço público.

O ciclo da inculcação das disposições, do ponto de vista daquele que as sofre, pode ter término com o casamento árabe, especialmente entre primos paralelos patrilaterais, como se verá a seguir. Nestas situações alguns expedientes são mobilizados, como viagens regulares para a Palestina, para possibilitar o convívio das crianças com avós, tios, tias e primos que residem ali, ou para preparar moças para o casamento e viabilizar aos jovens homens as socializações anteriores à escolha matrimonial. Com o casamento, um novo papel é atribuído, novas responsabilidades são contraídas e um novo ciclo educativo se forma.

Dentro do processo educativo, temos considerações explícitas sobre a honra, que é relacionada às questões que envolvem relações entre homens e mulheres. O véu parece ser a metáfora mais emblemática para as relações de gênero, segundo a compreensão de que se trata do objeto que representa e preserva a mulher das afrontas que podem atingir seu grupo familiar. Estas afrontas possuem formas específicas de reparação, que se configuram numa retratação moral frente à comunidade de expectadores e avaliadores do ato. Apoiada em Bourdieu (1965) sugiro que este jogo de desafio/resposta está presente na lógica da troca na colônia, e que suscetibilidades e expectativas de reparação aparecem nas situações em que estas pessoas intercambiam pessoas e objetos. 


\subsection{Com quem interessa casar e o que interessa ser}

Nesta seção amplio a discussão em torno da "família árabe" para demonstrar quais os elementos mobilizados por estes sujeitos para dar concretude às diferenciações de gênero sinalizadas na seção anterior. Aqui são elaborados mais dados em torno da "palestinidade" evocada como valor, proferidos a partir das expetativas de socialidades gestadas no ambiente doméstico. Também descrevo como as visitas, os encontros e os almoços são momentos importantes na produção de sujeitos moralizados. As discussões aqui aprofundam as circunstâncias em que as construções de gênero têm implicações nos negócios, pois carregam outras trocas entre homens e mulheres que podem clarificar as condições para o casamento.

Para a consecução de um casamento ideal, a interferência dos pais na vida dos filhos e o casamento virgem para as mulheres são fundamentais. Dona Carmem foi declaradamente oposta ao casamento de Ryan, pois alimentava o interesse de que ele se casasse com uma mulher árabe e muçulmana da qual ele já era noivo. Mas o rapaz havia engravidado a atual esposa, o que tornou forçoso o enlace. Ranya, que como outras mulheres da colônia também compartilharam este acontecimento, conta que Carmem continuava insistindo no matrimônio com a moça estrangeira, pensando inclusive em trazê-la para o Brasil. Mas Ranya orientou para que abandonasse o plano, porque "a moça só ia sofrer, depois que descobrisse a traição do noivo!". Ranya concluiu que o melhor era permitir o casamento com a brasileira, porque “apesar disso, é uma menina boa".

Isso demonstra que consaguinidade, mas também a manifestação de seus atributos, são cruciais para a atribuição do valor "árabe". Entre as mulheres citadas aqui e com as quais estes assuntos eram mais verbalizados, outras brasileiras tiveram melhor aceitação por terem ascendência árabe mesmo não sendo muçulmanas, como é o caso de Fátima. Na minha convivência também pude notar que outras moças brasileiras convertidas ao Islã são menos reprovadas do que as filhas de palestinos que não cultivaram a religião.

A preferência pela manutenção desse tipo de linhagem remonta ao início da formação do grupo, quando a reprovação do casamento com mulheres brasileiras culminava em ofensas verbais, fato relatado com evidente mágoa por Dona Graça. No dia em que esta interlocutora me revelou seus primeiros contatos com os palestinos, quando ainda era muito jovem, estávamos na cozinha de sua casa, na primeira vez em que eu havia sido convidada para um almoço. Falávamos de trivialidades e a conversa seguia cômoda quando eu comentei sobre o meu noivado. Dona Graça expressou grande surpresa 
e contentamento, me felicitou, rendeu graças a Deus e começou a mergulhar nas lembranças de como conheceu o seu falecido esposo. O depoimento me causou comoção e perplexidade pelo tratamento hostil que aquela mulher recebera, principalmente porque eu conhecia os homens citados. Mas apesar de tudo, conclui Dona Graça com ar triunfal: "sou mais muçulmana que eles tudinho"!

Notei que a partir daí ganhei certo tipo de confiança para receber comentários de parte das dinâmicas domésticas e íntimas dessas mulheres, ainda que o jogo de valores sobre o casamento não me fizesse esquecer do lugar que eu ocupava entre elas. A minha condição ficou muito clara num episódio ocorrido na ocasião da quebra de jejum, num domingo do mês do Ramadã. No intuito de estreitar os laços entre as famílias, no mês sagrado e repleto de indicações rituais para os muçulmanos, ficou acertado que todo o domingo a colônia palestina quebraria o jejum coletivamente.

O banquete preparado pelas mulheres era servido no salão de recepção da própria mesquita, onde as famílias também se concentravam para as orações previstas para aquele momento: homens no salão principal, mulheres na sala reservada em cima e crianças correndo e brincando juntas por todo o ambiente. Do mesmo modo era nítida a divisão entre homens, mulheres e jovens no salão de recepção, havendo visível aglomeração por sexo e faixa etária ou por família (pai, mãe e filhos). No intervalo entre o banquete e a oração seguinte, estávamos eu, Ranya e Dona Carmem, quando a cunhada de Ranya chegou e fez um comentário sobre o véu que eu usava, elogiou-me e disse que assim eu conseguiria uma proposta de casamento em breve!

Fiquei aturdida com a colocação, principalmente porque em campo eram constantes os comentários sobre a infidelidade masculina, que me fizeram temer, às vezes excessivamente, o fato de ter meus interesses de pesquisa confundidos com outras coisas. O mínimo sinal de desconfiança sobre minhas intenções sempre me preocupava e me deixava em constante alerta quanto aos meus modos e palavras. Como resposta ao comentário inesperado, neguei veementemente essa possibilidade e declarei que eu já estava noiva. Dona Carmem aproveitou a deixa para dizer, elogiosamente, que eu estava noiva de um “árabe”. Mas Ranya não deixou que aquilo provocasse qualquer sinal de aprovação, e completou rápido: "ele só tem nome árabe, mas não é um”.

Segundo a classificação de Ranya e outros homens, os filhos nascidos de mãe brasileira também são considerados palestinos, os que são educados na "cultura" e na "religião". Há vários casos dos que não puderam ser "salvos", principalmente os nascidos de 
mãe brasileira e que não são muçulmanos. O casamento entre “árabes” é, portanto, fundamental para viabilizar a "salvação" da família num meio em que as práticas divergem bastante das consideradas aceitáveis. Os discursos sobre preferências matrimoniais representam, portanto, expectativas da socialidade que alimentam as práticas de reprodução social da colônia, porque, como exponho a seguir, garantem o sistema de obrigações necessário além de se conjugarem aos interesses econômicos.

As trocas matrimoniais têm, por exemplo, implicações em torno dos negócios. As filhas que se casam com primos paralelos patrilaterais tem mais chances de continuar dentro do nicho familiar/empresarial, na mesma "casa". Isto porque aquelas que se casam com primos cruzados matrilaterais estão sujeitas a obrigações com os pais e irmãos do esposo e, portanto, com outra "casa". Os casos de admissão de cunhados (esposos das irmãs ou irmãos das esposas) para uma mesma "casa" são viabilizados pelo histórico de relações amigáveis entre as duas partes, o que pode resultar em parcerias comerciais. $\mathrm{O}$ "problema" das uniões entre duas "casas" diferentes pode residir num fato narrado de que, pela tendência que as mulheres possuem em compartilhar aspectos de sua vida familiar umas com as outras, informações sigilosas acabavam passando no fluxo dessas amizades.

Uma convenção importante é em relação ao divórcio. A regra comunicada pelas mulheres é a de que não têm direito nenhum sobre o patrimônio do esposo ${ }^{14}$, mas a decisão de manter o casamento mesmo em condições adversas recebe algumas justificações. Em outra ocasião, aproveitei para perguntar-lhe se, diante da "traição" do marido, as mulheres não optavam por terminar o casamento. Ranya respondeu-me que não porque geralmente as palestinas são religiosas e honram a família, além de serem responsáveis pela criação dos filhos, e ressentem muito uma segunda escolha conjugal do marido, o que não é visto com bons olhos nem pelos próprios pais que não permitem que o primeiro matrimônio de suas filhas seja com homens já casados.

O sistema de trocas conformado pelo "casamento árabe" tem uma metáfora curiosa na ocasião do Ramadã, pois explicita trocas de responsabilidades. Este período é marcado por representações do sistema de deveres e direitos entre os membros de uma "casa". Uso o caso de Ranya como exemplo do que ela mesma expôs esperar nesse período. A mesma revela que o seu pai, os irmãos, os irmãos do pai, os filhos dos irmãos (apenas dos homens), o marido e o sogro, tem o que ela chama de "direitos" sobre ela. Estes homens também são os únicos aos

\footnotetext{
${ }^{14}$ Fátima, que já passou pela experiência do divórcio, conta que as jóias são os únicos bens que a mulher pode levar se o casamento terminar, regra que, segundo ela, funciona como o principal motivo para que não cogitem a decisão, mesmo que estejam insatisfeitas com a relação.
} 
quais ela pode apresentar-se sem o véu, pois são aqueles nos quais admite a consanguinidade e que são proibidos para o casamento (nesta lógica, o homem com quem casou conquistou a situação de consanguinidade, pois também pode vê-la sem o véu).

Nesta concepção, os homens têm certas obrigações para com as mulheres, como a de dar apoio, ajuda material, fazer visitas, ou qualquer coisa que a mulher estiver precisando. Para Ranya, o homem que respeita a sua obrigação "chega com o presente na mão", pois o presente e a visita significam uma demonstração de que Ranya tem um "valor", pois mostra ao que é visitado que ele está presente na vida de quem visita. A obrigação da mulher, por sua vez, é a de obedecer, respeitar o "nome da família", ser boa esposa, boa filha e receber bem as visitas, tarefa que se intensifica na ocasião do Ramadã, quando a quebra do jejum é feita entre famílias de uma mesma “casa", e cada uma oferece um jantar especial em um dia previamente combinado.

Apesar de Ranya manter obrigações com sua família de origem, por ter se casado com um primo cruzado matrilateral, no Ramadã ela não tem a oportunidade de receber seus pais, seus tios e seus irmãos para a quebra do jejum, uma vez que deve atender às responsabilidades junto à família do esposo. Na celebração do fim do Ramadã, o dia do Eid-ul-Fitr, deles também se espera uma oferta de presentes ou de dinheiro. Em contrapartida, a família de Ranya (ela, o esposo e os filhos) deve retribuir com outro jantar para aqueles de quem recebeu, mas a responsabilidade não recai diretamente sobre ela, e sim sobre o seu responsável imediato, o esposo. Nessa ocasião as mulheres costumam caprichar na recepção dos convidados, oferecendo-lhes a comida tradicional para a ocasião.

Ranya conta que no dia do Eid-ul-Fitr alguns homens dão o correspondente ao salário de um mês para as mulheres ou às vezes a quantia que conseguem juntar por meses, e para cada mulher se dá um valor diferente (para a mãe é comum se dar um valor mais alto por exemplo). Mas em Manaus, é difícil que estas relações se dêem tal como disse, primeiro porque a maior parte da "família" a qual se refere costuma estar na Palestina, segundo porque isto varia de acordo com a situação econômica dos envolvidos e com a presença/ausência dos mesmos. A condição migrante remodela as práticas de ajuda e assistência mútua, que se dá em diferentes tempos e por diferentes modos, como transferência em dinheiro, envio de objetos, comida e visitas.

As visitas ou o encontro entre os parentes nos termos que define Ranya, são uma constante no cotidiano destes indivíduos. A ocasião da chegada ou do retorno à Beni Naim é ocasião para muitas visitas formais, "principalmente ali”, disse Ranya, “onde as pessoas não mudam e continuam com o mesmo pensamento". O primeiro almoço que participei na casa de 
Dona Graça foi oferecido como boas-vindas para uma amiga sua, palestina, que havia retornado da terra. Neste sentido, Ranya esclarece o motivo para manter contato com a segunda esposa, que é brasileira, de um palestino residente em Manaus. Ranya diz que é censurada pelas demais mulheres por isso, e explica: "eu não posso deixar de falar com ela. Ela veio me visitar quando a minha filha nasceu, e também foi ver o meu filho no hospital".

Assim como o demonstram as práticas matrimoniais, outros processos domésticos como as visitas, as refeições e demais celebrações são momentos de produção de moral selves, tal como apontado por Jean-Klein (2003). Embora a afirmação da autora seja construída no cenário das tensões emergentes do estado-nação palestino, quando estes processos sofreram explícita politização durante a intifada palestina, tais eventos figuram como processos tradicionais importantes na constituição de sujeitos morais. Nos parâmetros de sua investigação, Jean-Klein identifica como estes elementos e demais definições em torno do parentesco funcionam como símbolo político poderoso, dando novos contornos às práticas consideradas "antigas", tratando-as como ideal de organização familiar.

Ainda que apelos políticos não tenham sido abordados pelos interlocutores apresentados aqui, distinções entre "moderno" e "antigo" são frequentemente utilizadas para exemplificar como os momentos de produção de moral selves se dão em Beni Naim. Os interlocutores que não nasceram nesta localidade, os brasileiros ou alguns palestinos nascidos em Manaus são quem mais fazem este tipo de observação. Uma neta do Sr. Cid dividiu comigo algumas impressões que teve no período que passou de férias com a família do avô na Palestina. A garota estranhou muito o fato de ter recebido visitas durante praticamente todos os dias que passou ali, e não eram apenas de parentes, mas de praticamente toda a cidade que vinha conhecê-la e reencontrar parte da família de Cid.

Fátima também contou sobre como foi confrontar a mentalidade que reconheceu como sendo "conservadora", na década de 1980 quando morou em Beni Naim com os filhos e o esposo. Disse que ficou chocada quando viu que as mulheres almoçavam na cozinha, e que comiam apenas "os ossos", enquanto que os homens faziam suas refeições em sala apropriada e em bandejas e pratos caprichosamente arrumados com as melhores carnes. Vendo isso ela não aguentou e partiu com os filhos para almoçar onde os homens estavam comendo, as mulheres foram atrás para lhe puxar mas ela continuou. Fátima conta que para a surpresa das mulheres, os homens a receberam muito bem, inclusive lhe deram um prato e deixaram que ela se servisse a si mesma e aos filhos primeiro. Agindo dessa forma, a interlocutora conta que "revolucionou" aquele lugar. 
Fátima também conta outro caso que também exemplifica o tipo de comportamento esperado para cada sexo. Aconteceu no mesmo período em Beni Naim, entre seus filhos e as demais crianças. Certo dia, ela percebeu que algumas meninas passavam com machucados na cabeça. Achando aquilo estranho, foi procurar saber e descobriu que era o seu próprio filho atirando pedras nas meninas que passavam por perto. Fátima repreendeu vigorosamente o menino com palavras e tapas, no que foi observada por outras mulheres que interferiram na ação da mãe. As mulheres foram lhe chamar a atenção dizendo que Fátima não deveria bater nele já que era um menino, este devia continuar em suas brincadeiras.

Ainda que a criação no lar esteja atualmente repleta de ações com a finalidade de internalizar construções de gênero, os casos que meus interlocutores acionavam como sendo indícios de "atraso" são referências às manifestações excessivas ou muito explícitas do princípio de conservação da honra e de valores anexos. Portanto, o modo como esses princípios são postos em prática, como a educação acontece ou como os eventos são marcados, constituem as práticas "modernas" ou "antigas". A maneira como se dão as "visitas", os rituais de casamento, as situações de morte por questões de "honra", e até a poligamia são vistos como sendo frutos de uma mentalidade "tradicional".

Sobre a opção de ir com os filhos pra Palestina sem a companhia do esposo, Ranya nega veementemente esta possibilidade. Além de temer uma segunda escolha conjugal do esposo, a mesma revela não ter condições de educá-los sozinha, pois "quando os meninos crescerem eles não vão mais me ouvir, porque eu sou mãe. Por isso que Deus fez o casal homem e mulher, não quer dizer que o homem deva trabalhar e a mulher ficar em casa”. Referências como esta de que "os homens não ouvem as mulheres” são bastante recorrentes, e apareciam espontaneamente sem que estivéssemos em diálogo formal, muitas vezes eu apenas presenciava situações nas quais meus interlocutores expressavam esse preceito.

Dentro do discurso nacionalista palestino analisado por Kanaaneh (2002), a maternidade definida pelas mesmas funções colocadas pelos interlocutores em Manaus sofre o acréscimo de uma carga política. Neste quadro, a maternidade assume posição política importante, mas a paternidade é considerada mais dominante e determinante da identidade, pois o casamento de mulheres palestinas com homens de outras nacionalidades configura traição ou perda para a nação, uma vez que seus filhos não serão palestinos, enquanto que o contrário, o casamento de homens com mulheres não palestinas, é visto como acréscimo à nação. Da mesma forma, inseminações artificiais de doadores de espermas não-árabes ou a adoção de crianças não-árabes, são lidos nos mesmos termos. 
Neste sentido, a preferência por filhos homens é predominante, pois possibilita a condição de expansão da família. Para a Kanaaneh (2002), os discursos produzidos pelo nacionalismo palestino vêm legitimar a dominância dos homens sobre as mulheres. Nesta lógica, os homens são importantes contribuições à nação por configurarem seus futuros defensores. Assim, é apenas produzindo meninos que as mulheres verdadeiramente se tornam mothers of the nation. Outra prática "tradicional" que recebe força neste contexto é o da organização clânica, como importante fator de vínculo com a terra, de sua conexão com o povo, provada a partir de uma prática de parentesco patrilinear.

Mas o que há de intrigante nessa informação é que ela permite pensar na transmissão ou redefinição das características deste tipo de socialidade em outros níveis de organização. Os laços materiais entre as pessoas, ou o que pode ser lido como parentesco a partir dos dados históricos sobre a organização clânica, são criados com a transferência da substância masculina, uma herança do aspecto da primazia de um parentesco biológico da organização clânica descrita. Neste sentido, pode-se fazer valer a compreensão clássica de que o parentesco, ou pelo menos a descendência, se produz com a procriação sexual, tal como explicados por Morgan (1870), Fortes (1970) e Lèvi-Strauss (1967).

A crítica do pós-guerra ao paradigma estrutural-funcionalista seguiu-se à crítica do parentesco como um domínio de relações específicas. Segundo Peirano (1997), a antropologia dos anos 40 e 50 revelou uma compreensão da realidade social através da ideia de distinção de sistemas (de parentesco, políticos, econômicos, religiosos, etc.), em consonância com as rubricas modernas que nem sempre se aplicam bem a outras sociedades. Neste movimento, o parentesco não pôde mais se construir simplesmente como um sistema provedor de direitos e deveres para uma reprodução ordenada da vida humana. Essa preocupação foi propulsionada principalmente com o desenvolvimento dos estudos feministas e sua agenda no sentido de entender o fundamento da desigualdade entre os sexos.

Portanto, as análises não rendem identificações do parentesco como, por exemplo, um aspecto do amplo sistema de desigualdades no qual o gênero constitui uma dimensão fundamental. A partir da análise da construção do gênero em sistemas sociais específicos, iniciou-se o questionamento dos principais pressupostos da teoria do parentesco, como a noção elaborada por Fortes (1970), de que este domínio se realiza a partir de uma dicotomia entre "doméstico" e "político/jural". 
Segundo Yanagisako e Collier (1987), isso deixa entrever que a mulher está associada primariamente à esfera doméstica, dedicada à sexualidade e ao cuidado com os filhos, enquanto que os homens estão associados à esfera pública de regras legais e autoridade legitimada. Diante disso, os estudos feministas questionaram a aparente naturalidade da relação mãe/filho e a suposta "autoridade" masculina em sistemas sociais particulares. Neste sentido, o que se considera "esfera doméstica" podia apenas ser entendida pela interação simultânea com outras esferas, ou ainda, que qualquer conceitualização sobre feminilidade só adquirem sentido dentro de um sistema de significados. E ainda, as ações e relações de parentesco ainda devem ser declinadas em termos de religião, nacionalidade, gênero, etnicidade, classe social e o conceito de pessoa, em uma articulação semelhante da que aponta Carsten (2004).

Mariza Peirano (1997) alerta para a recuperação da relativização formulada por Marcel Mauss, com a ideia de fato social total. Para este autor, tal ideia precisa funcionar como princípio basilar para os antropólogos, por possibilitar uma investigação da "totalidade da configuração social, aquilo que corresponde neles ao que conhecemos, e em nós ao que eles conhecem; é preciso o esforço de construir aqui e lá fatos comparáveis" (PEIRANO, 1997, p. 18). Isso tem implicações importantes quando as configurações que estudamos se consideram "modernos", pois teoricamente a construção de fatos comparáveis seria facilitada, ou até desnecessária. Por isso, Peirano (1997) alerta para a recuperação do sentido mais agudo de fato social total, que apregoa a abordagem holista para quaisquer situações, valores, ideias e socialidades, algo que exige antes de tudo a elaboração de uma antropologia da própria modernidade.

Nessa linha, as categorias são socialmente construídas a partir de símbolos e significados, estes são relativamente estáveis e codificam distribuições particulares de prestígio, poder e privilégio, se realizam na prática social e por isso não são estáticas nem atemporais e autoperpetuáveis. Os significados disponíveis são os meios pelos quais as pessoas monitoram e interpretam suas ações e as dos outros e, portanto, são difíceis de prever e traduzir em conceitos fixos. Dentro deste esforço de dissolução de sistemas autônomos, de categorias rígidas ou de fatos supostamente semelhantes, propus entender a produção e reprodução da colônia palestina de Manaus, colocando em suspenso a própria ideia de colônia e dos sistemas econômico e de parentesco como fontes separadas de conformação das práticas. 
Argumento que as relações que reconhecemos como de parentesco e aquelas que identificamos como econômicas são mais efeitos da combinação entre regimes de troca num contexto de reprodução social, do que da existência de esferas independentes e autorreguladas de significação. Sendo assim, identifico princípios transversais a todas estas práticas, demonstrados nas relações que produzem identidades sociais pelas distinções que provocam sobre o que é trocado, com quem, em quais circunstâncias e para quais fins. Com a apresentação das disposições engendradas na subjetivação das mulheres, pretendi propor que a colônia também existe como expressão da economia do parentesco e do comércio.

\subsection{Evidências da família bilocal}

Na seção que conclui esta dissertação, gostaria de enfatizar que é a condição de bilocalidade das famílias que possibilita a conformação das moralidades efetivadas no espaço do mercado e da casa. Reitero que por bilocalidade não quero me referir à dupla morada dos filhos relativas à família de origem da mãe e à do pai. Mas a dupla morada constituída espacialmente por uma filiação única, a patrilateral. Não se trata da bilateralidade do sistema de filiação, mas da possibilidade de a "casa" estar fisicamente e simbolicamente em dois contextos distintos: Manaus e Palestina. As "casas" a que me refiro são patrilocais ou virilocais, e por isso a família possui uma organização doméstica semelhante aqui e lá.

Dentro desta organização, os casos em que a mulher vai morar com as filhas na Palestina remete à sua transferência para junto dos pais do esposo que residem ali, ou mesmo para uma residência própria do esposo. As diversas práticas que têm como fím alimentar materialmente e simbolicamente os vínculos com a "casa", e que possibilita estes interlocutores pensar em sócios e cônjuges potenciais, articulam principalmente a família do esposo, ou seja, os núcleos familiares de seus tios paternos e irmãos. Assim, as visitas e as situações que conectam estes sujeitos são bem marcados. As recepções de parentes, amigos e mulheres palestinas para casar em Manaus, bem como os reflexos que os conflitos na Palestina apresentam entre estes interlocutores, fortalecem a presença da Palestina.

O mesmo se dá em sentido inverso, pois o próprio fato de se construírem casas luxuosas em Beni Naim é um marco da importância que o outro lado da vida em Manaus tem 
para a totalidade da vida da família e da colônia. É como se em uma via tivesse a transmissão de recursos materiais, e em outra a transmissão dos recursos simbólicos, ambas alimentando e elaborando mutuamente novos sentidos para a família palestina que se produz e reproduz bilocalmente. $\mathrm{O}$ fato de os palestinos encontrarem melhores oportunidades no comércio de confecções, e insistirem na manutenção de parte da família em Beni Naim, parece um teimoso princípio de que devem continuar aqui e lá.

A permanência em Manaus poderia oportunizar convivialidades novas e proporcionar iniciativas contratuais, como de fato aconteceu entre os primeiros imigrantes, quando eram mais comuns os casamentos com brasileiras e brasileiras descendentes de sírios e libaneses. A proximidade também acontecia mais facilmente nos negócios, pelo sistema de "ajuda" que se estendia a qualquer conterrâneo e propiciava um convívio mais estreito da colônia. Mas atualmente, estes casos são poucos, uma vez que as relações têm se mantido bilocalmente, com a produção de partes contratuais de um modo tradicional assegurada pelas possibilidades de reprodução da "casa" nos dois lugares.

Todos fazem questão de manter suas propriedades na Palestina, e por mais que estejam "passando fome", como disse certa vez uma interlocutora brasileira, eles não vendem suas casas ou suas terras. É pra eles um dever e uma obrigação "não esquecer da terra natal”, e seu cumprimento parece ser avaliado pelos demais. Neste contexto, encontra significação a resposta de Youssef, quando interrogado sobre o porquê da permanência de alguns dos seus irmãos em Beni Naim, que trabalham como pequenos comerciantes e agricultores: “eu já trouxe dois! E também não pode esvaziar a família lá né?!”

Nota-se, pois, que outra tendência possível seria a de fazer todos os parentes gozarem do sucesso econômico e das possibilidades de emprego em Manaus. Acontece que em Beni Naim estão as suas casas e as terras de família, terras herdadas e de dificílima aquisição, e os discursos que apelam para esta origem e a necessidade de sua manutenção são infindos. Ocorre muito frequentemente o que é descrito por Cid: "as pessoas trabalham lá fora e alimentam a família lá dentro"; "se sobrar dinheiro não aumenta o comércio, ou constrói uma casa melhor ou coloca o filho para casar".

A necessidade de "mandar buscar" uma mulher palestina para casar, mas também de enviar a esposa de volta à Palestina para educar seus filhos na "mentalidade palestina", encontra viabilidade em quase toda a história contada sobre a imigração palestina em Manaus, e depende dos espaços cultivados como "casas". Jamal representa um caso atual desta decisão. Ele tem três filhas, a mais velha é adolescente e "já estava se sentindo pressionada 
pelas colegas da escola por não fazer o que elas faziam”. Jamal imprime indignação na voz ao comentar o caso, pois para ele, é "lógico" que as mulheres devam casar virgem, e que "o primeiro homem a tocá-las tem que ser seus maridos!"

Jamal atribui aos meios de comunicação a culpa pelo comportamento sexual reprovável e muito difundido na sociedade brasileira, e a decisão de enviar as três filhas acompanhadas da esposa para Beni Naim foi a melhor alternativa para "salvá-las". O termo "salvar" foi utilizado por vários interlocutores para se referir a reprodução da subjetividade pela família, que também é o habitus esperado na colônia, referente aos processos de socialização dentro do que consideram aceitável. Os eventos nacionais para o encontro entre jovens palestinos é um exemplo disso. Nesses encontros ocorridos em 1979 e 1984, os homens agiam como pais e líderes preocupados com a preservação da "palestinidade". Os encontros se davam na forma de acampamentos cuja principal finalidade era a de promover a socialização entre jovens palestinos e viabilizar casamentos entre eles, já que a instituição familiar é crucial nesta reprodução.

Atualmente, como a maioria das famílias palestinas de Manaus possuem condições de bancar viagens para a Palestina objetivando estes fins; a organização de acampamentos foi abandonada, também em consonância com as mudanças das prioridades e sujeitos dos quais depende essa articulação. Por isso, o dado apresentado aqui destoa do padrão de deslocamento de famílias apresentado por Denise Jardim (2009) sobre o coletivo palestino residente no Chuí (RS). O provérbio árabe "as mulheres voam com seus maridos" encontra a síntese explicativa para o funcionamento da vida familiar que recebe as noras na unidade doméstica da parentela do noivo. Este princípio explica a multilocalidade das famílias e expõe as dificuldades práticas e afetivas de manter a parentela em deslocamentos.

Jardim (2009) não identifica circunstâncias de distanciamento entre os cônjuges como mecanismo de reprodução social, pois a continuidade do grupo responde pelas práticas de "voar com os maridos" como recorrência de uma "tradição". Segundo a autora, em estudos sobre parentesco e povos de "origem árabe" as definições sobre uma "família árabe" são muito imprecisas, mas a sua referência enquanto um "valor" foi bem evidente nos discursos dos sujeitos de sua pesquisa. A autora identifica que uma solidariedade geracional e de gênero cooperam para a manutenção da parentela no deslocamento, criando a "presença ausente" de muitos sujeitos na determinação nas vidas de outros. O provérbio, apesar de expressar o resultado estrutural das trocas matrimoniais (masculino), contribui para pensar as habilidades das mães e tias nas circulações de noivas. 
Apesar de ser um mecanismo que tem tido bons resultados na promoção de uma "família árabe", mulheres como Ranya não concordam com o retorno de esposas acompanhadas das filhas para a Palestina sem os maridos. Para ela, isto foi recorrente no passado. Os "novos", porém, aprenderam com essa experiência que não costumava dar certo, uma vez que era muito comum que os homens se casassem com brasileiras, algo muito ruim para suas esposas palestinas e que acabava prejudicando o primeiro casamento. Mas a decisão de voltar à Palestina é relativamente bem aceita segundo ela, principalmente porque as mulheres costumam ficar muito tempo dentro de casa.

Muitas palestinas em Manaus não podem sair devido aos compromissos domésticos, isso pode explicar a baixíssima frequência das mesmas nas orações de sexta-feira na Mesquita, para onde os homens costumam ir com mais frequência. Para Ranya, isso as impede de criar vínculos mais fortes com a cidade, diferente dos homens que "são mais livres" e por isso, têm melhor adaptação. Em campo, conheci uma das noras de Graça, com menos de 5 anos de residência em Manaus. Ela espera utilizar este recurso e o fato de ser mãe de duas meninas para voltar à Palestina. A sua família de origem e a do esposo não gozam de uma situação financeira muito confortável, de modo que em Manaus ela se responsabiliza sozinha pela educação das duas filhas e das tarefas domésticas, não possuí automóvel e não sai de casa sem a companhia de um familiar e das meninas.

Não é demais reforçar o dado de que a principal condição para voltar à Palestina por conta da criação da prole é a posse de filhas. Entre os casos antigos desta decisão destaco o das filhas de Farid (que não aderiram à religião e aos costumes, assim como a mãe delas, mesmo sendo filha de sírio); as sobrinhas de Farid, filhas de Fátima; e no mesmo período as filhas de Nasser com Carmem. Atualmente tomei notícias de outros casos, como o da esposa de Youssef, da esposa de um dos seus irmãos que trabalha consigo, e a esposa de Jamal. Estas últimas não foram acompanhadas de seus cônjuges.

Em todos estes casos, o motivo girava em torno principalmente da "preservação das filhas". Sugiro que, devendo por conta das características de instituição, a família também é permeável às influências externas decisivas para a sua constituição, reprodução e manutenção do conjunto das relações em que está inscrita. Mas o que se quer da família nestes casos é contra as pressões externas identificadas como sendo brasileiras. Tais pressões, como ideias veiculadas sobre o comportamento das pessoas e mesmo as relações entre os sexos que se percebem a olhos nus, atingem os membros da família de forma incontrolável. Em Beni Naim, as relações que se pretendem produzir e reproduzir na família podem ter eco em mais “casas", instituições ou pessoas que compõem o local. 
Ainda que se espere a mesma disposição para produção e reprodução da "casa" pelos filhos homens, sugiro que as "pressões brasileiras" podem marcar irreversivelmente os corpos femininos, como a perda da virgindade que é uma condição fundamental no “casamento árabe". Os rapazes palestinos não recebem a mesma orientação em questão de relacionamentos sexuais, muitos até namoram com jovens brasileiras, embora o casamento não seja apoiado nestas circunstâncias. Além disso, uma vez que os homens são preparados para assumir a atividade comercial, ou mesmo para exercer outra atividade profissional, é importante que permaneçam junto do pai e da parte masculina da família que possui esses compromissos. Não quero dizer que a educação é negada às filhas, pois não encontrei situação em campo que sugerisse isto. Mas há diferença entre o estímulo empregado para as carreiras de homens em mulheres, pois não percebi meninas sendo incentivadas a engajar na atividade comercial.

Dito isto, retenho que ambos, meninos e meninas, sofrem com as disposições que permitem a preservação da casa, e também a do comércio, nas configurações que julgam adequadas. Nos dois espaços, casa e mercado, se espera relações e comportamentos específicos para cada sexo. A infraestrutura produzida por ações individuais para atender necessidades de família, e por ações coletivas em nome da "colônia" ou da própria Palestina, oferecem os contornos da comunicação entre os dois espaços da casa ou de produção da palestinidade. Por infraestrutura, entendo os recursos difundidos na colônia como as mídias digitais, os canais de transferência de dinheiro, de câmbio, compra e venda de dólar, os destinos comuns para doações, as viajens de pessoas, a circulação de objetos encaminhados em nome do viajor ou em nome de outrem, para serem distribuídos na rede acessada pelo intercambista.

Nestes sentidos, sugiro que as práticas verificadas ou os dados construídos só têm sentido dentro desta perspectiva de bilocalidade. Como foi demonstrado, a consecução de negócios entre parentes e de produção da família existem dentro da consideração das relações mais amplas disponíveis, que pensam em quem está aqui e em quem está lá, e em como viabilizar as conexões necessárias. Os processos de "puxar" parentes, de "mandar buscar uma mulher pra casar", de "mandar dinheiro", "construir casa lá", casar o filho, "ajudar" ou "dar uma loja", são todas iniciativas que conectam campos sociais numa construção social única (Feldman-Bianco, 1995). São ações agenciadas dentro de uma perspectiva de preservação da "casa" e do "patrimônio" que não são vencidas pela existência de fronteiras geográficas, mas que articulam com os meios para superá-las. 
Isto porque, utilizando a proposta de Barnes (1969), os tipos das relações interpessoais são elementares para a configuração da família árabe e da colônia, e de certa forma, prescinde a distância física, ou não limita-se à ela. Se levarmos em conta que as relações são mais importantes que as novas possibilidades dos novos contextos da migração, percebemos que elas continuam gerando circuitos de saberes, bens e projetos e contêm o potencial gerador da colônia. Faço valer as implicações da transnacionalização de famílias verificada por FeldmanBianco (1995), pois as estruturas domésticas transnacionais acabam por marcar a insularidade desses imigrantes na vida social de Manaus. 


\section{CONSIDERAÇÕES FINAIS}

Grande parte da produção acadêmica sobre imigração árabe no Brasil tem reforçado um perfil de inserção urbana desta população. Nas conclusões deste trabalho também reforço a importância desta consideração para as implicações analíticas do meu estudo, pois consiste numa dimensão importante dos modos de existir destes indivíduos. A atividade de mascate no contexto da Zona Franca de Manaus favoreceu que estes sujeitos tivessem lucros suficientes para adquirir seus próprios estabelecimentos comerciais. Já que as mercadorias eram abundantes e a demanda por elas também, os mascates conseguiram posição privilegiada entre os novos fornecedores e os novos clientes. Isso proporcionou a emergência de compromissos políticos específicos, em torno dos quais os interesses eminentemente "palestinos" também eram concretizados. Através da base das relações interpessoais em Manaus, alguns interlocutores dirigem processos políticos em prol da colônia.

As impressões dos interlocutores sobre o trabalho como mascate possibilita correlacionar suas experiências com expectativas que não correspondem ao regime de mercado e aos estilos de vida predominantes em Manaus. Neste sentido, os seus discursos adquirem sentido no contexto da reprodução da colônia, pois se estruturam na reconstrução de um ato fundante e de uma "ancestralidade". O ato de se adaptar ao mercado de Manaus revela valores acerca do "trabalho" e da "família", compartilhados e avaliados pela colônia. Isto emerge no que chamei, inspirada em Keane Webb (1997), de narrativas triunfalistas, pois articulam um pensamento sobre o passado que tem em vista ideais para o presente e projetos para o futuro

Descrevo que a colimada "progressão de vida" é narrada com sinais de exaltação do trabalho árduo, pela conformação com prescrições comportamentais de caráter religioso, mas também como processo que chama para si parentes e responsabilidades de cunho doméstico. A "progressão" é resultado não apenas do acúmulo de capital, mas, sobretudo, do investimento em relações através das ajudas e das dinâmicas que produzem relações duráveis. Tais relações se definem por caracterizar sujeitos morais em diferentes tipos de troca, como as que ocorrem nos negócios pelos recursos transacionados, e na constituição da "família árabe" com o casamento, que atende expectativas sobre trocas de responsabilidades e obrigações permeadas por construções de gênero. 
Retenho que estes processos têm íntima relação com as dinâmicas de trabalho, pois dão direcionamento aos compartilhamentos com os locais, aos compromissos políticos e a outros interesses. Tento demonstrar como estes interesses são combinados com as táticas de reprodução no comércio, que chamo de "diáspórica" ou "cosmopolitanismo diaspórico". A reprodução no comércio depende da manutenção da característica "familiar" das empresas e que, portanto, depende do cultivo do aspecto "familiar" em outros espaços. Argumento que o cultivo das relações familiares se dão sobretudo com a manutenção das conexões com a Palestina.

Estas conexões são uma espécie de infraestrutura criada para viabilizar condições de "palestinidade", representadas pelas viagens, pelos circuitos de saberes, bens e projetos, com o interesse de cultivar subjetividades palestinas para ações esperadas no "mercado" e na "casa". Isto é evidente no tipo de relação de trabalho que se dá entre parentes, e no tipo de "família" que concebem como ideal. Os processos de subjetivação de mulheres e as situações que materializam elaborações de gênero, são muitas vezes pungentes, e demonstram o quanto a mulher está associada à reprodução do costume, sendo responsáveis por inculcar disposições no espaço privado enquanto que os homens são os protagonistas do espaço público.

Todas estas táticas estão permeadas por políticas de valor sobre o ideal esperado para os negócios e a família. Por isso busco sentido na noção de rede para tentar modelar estas relações e demonstrar que as condutas individuais dependem de negociações e da influência de parentes que vivem em dois contextos distintos. Ancorei-me na idéia de "bilocalidade" para expressar os tônus e as experiências entre a arena da conduta individual e dos processos restaurativos pela via das manutenções e preservações. Lançando desta organização da vida familiar, pretendi destacar que a configuração da colônia sempre dependeu de ativações mais ou menos intensas de recursos “palestinos”, e que eles são resguardados porque a família na palestina não é esvaziada.

Dentro disso passo a demonstrar a pertinência de se pensar em espaços onde se conjugam as ações domésticas e as ações comerciais: os espaços da "casa" e do "mercado". Proponho que a produção de sujeitos morais palestinos se dá pela subjetividade gestada no âmbito da casa, mas que é viabilizada pelos recursos angariados no âmbito da arena da conduta individualista do mercado, e que mesmo este espaço sofre com o influxo de ações domésticas, pois para que a empresa familiar possa se reproduzir, é preciso que se alimente das condições gestadas na casa em sua organização espacialmente bilocal. A subjetividade palestina também é gestada de modo público, através da Sociedade Árabe-Palestina de Manaus, que também promove processos transformativos, na medida em que incorpora os recursos capturados no âmbito do mercado. 
Por isso considero que a compreensão dos regimes de troca é tão necessária como quadro analítico, uma vez que fornecem subsídios para a compreensão de mecanismos elementares de produção de relações duráveis. No intuito de buscar outras relações geradas pelas identificações políticas, o recurso à economia da dádiva permitiu delinear afinidades eletivas com a noção de honra e valores contíguos à lógica desafio/resposta. Assumo que tais procedimentos também demarcam a insularidade destes imigrantes na vida social de Manaus, pois cria um lugar no qual apenas determinados sujeitos podem atuar.

A relação balizada pela economia da dádiva revela critérios de confiança, competição e expectativa de reciprocidade. Aos recursos transacionados nestas relações se atribui grande força ou efeito moral, de modo a criar assimetrias. Nestas dinâmicas identifico uma fonte de conflito estruturante das relações, pela medição de forças através do dinheiro, em que se sobressaem os valores citados. Prova da existência de valores conflitantes com a lógica da acumulação eficiente ou racional são as práticas de conversão do dinheiro em benefícios para a colônia e para a Palestina. Esses casos revelam uma concorrência pelo prestígio que as formas sociais da vida em colônia podem gerar. 


\section{REFERÊNCIAS}

ABDALATI, Hammudah. O Islam em foco. São Paulo: Federação das Associações Muçulmanas do Brasil, 2008.

ACIOLI, Sonia. Redes sociais e teoria social: revendo os fundamentos do conceito. Informação \& Informação, Londrina, v. 12, n. 1, esp. 2007.

APPADURAI, Arjun. 1986. "Introduction". In: The social life of things. Commodities in cultural perspective. Cambridge: Cambridge University Press. pp. 3-63.

BARNES, J. A. Redes sociais e processo político. In: FELDEMAN-BIANCO, Bela (Org.). Antropologia das Sociedades Contemporâneas - Métodos. São Paulo: Global, 1969.

BARRETO, Alessandra Siqueira; DUTRA, Rogéria Campos de A. Quando o campo se move: trajetórias e projetos entre redes locais e transnacionais. Antropolítica: Revista Contemporânea de Antropologia, n. 32, p. 65-85, 2012.

BENCHIMOL, Samuel. Manáos do Amazonas: Memória Empresarial. Vol. I. Manaus: Governo do Estado do Amazonas; Universidade do Amazonas; Associação Comercial do Amazonas, 1994;

BOISSEVAIN, J. Amigos de amigos: redes sociais, manipuladores e coalizões. In: FELDEMAN-BIANCO, Bela (Org.). Antropologia das Sociedades Contemporâneas Métodos. São Paulo: Global. 1974.

BOISSEVAIN J. The Place of Non-Groups in the Social Siences. Man 3, p. 542-556, Dic., 1968.

BOTT, E. Family and Social Network: roles, norms, and external relationships in ordinary urban families. London: Tavistok, 1971.

BOURDIEU, Pierre. Espíritu de família. In: NEUFELD, Grimberg; TISCORNIA Wallace (Comps.). Antropología social y política. Hegemonía y poder: el mundo en movimento. Buenos Aires: Eudeba.

O sentimento de honra na sociedade cabila. In: PERISTIANY, J. (org.). Honra e vergonha: valores das sociedades mediterrâneas. Lisboa: Fundação Calouste Gulbenkian: 1965. p. 159-195.

CABREIRA, Márcia Maria. Um estudo sobre a cultura brasileira: o caso da imigração Síria e Libanesa em São Paulo. Disponível em: <http://observatoriogeograficoamericalatina.org.mx/ egal9/Geografiasocioeconomica/Geografiacultural/07.pdf.>. Acesso em:

CARSTEN, Janet. After Kinship. New York: Cambridge University Press, 2004.

CARVALHO, Anabela Soriano. Empresários em Tempo de Guerra O caso de Moçambique, 1974-1994. Lusotopie, v. 15. n. 1, p. 103-118, 2008.

CARVALHO, Marcelo Bastos Seráfico de Assis. O empresário local e a Zona Franca de Manaus: reprodução social e globalização econômica. 2009. Tese (Doutorado) Universidade Federal do Rio Grande do Sul, Porto Alegre, 2009. 
CASTRO, C. M. A Liga da Juventude Islâmica e a construção de identidades muçulmanas no Brasil. 2007. Tese (Doutorado) - Universidade Federal de São Carlos, São Carlos, 2007.

COLLIER, Jane F.; YANAGISAKO, Sylvia J. Towards an unified analysis of gender and kinship. In: COLLIER, J. F.; YANAGISAKO, S. J. (Org.), Gender and Kinship; essays towards an unified analysis. Stanford: Stanford University Press, 1987.

DOUGLAS, Mary. 1958. Raphia cloth distribution in the Lele economy. Africa, v. 28, n. 2, p. 109-122.

EL KADI, Nágila Ibrahim. Migração, religião e identidade: imigrantes libaneses drusos no Brasil. In: CONGRESSO INTERNACIONAL DE HISTÓRIA DA UFG/JATAÍ, 3: História e Diversidade Cultural. 2012. Jataí. Anais ... Jataí: UFG, 2012. Realização Curso de HistóriaISSN 2178-1281.

ESPÍNOLA, C. V. O véu que (des)cobre: etnografia da comunidade árabe muçulmana em Florianópolis. 2005. Tese (Doutorado) - Universidade Federal de Santa Catarina, Florianópolis, 2005.

FELDMAN-BIANCO, Bela. A criação de uma nação (portuguesa) desterritorializada e a transnacionalização de famílias. Cadernos CERU, v. 6, n. 1, p. 89-104, 1995.

. A Família na diáspora e a diáspora na família. In: HOLANDA, Heloísa Buarque de; CAPELATO, Maria Helena Rolim. Relações de gênero e diversidades culturais nas Américas. São Paulo: EDUSP, p. 253-273, 1999.

FERREIRA, F. C. B. 2007. Entre arabescos, luas e tâmaras - Performances Islâmicas em São Paulo. Tese de Doutorado. Universidade de São Paulo.

FONSECA, Claudia. Família, fofoca e honra. Etnografia de relações de gênero e violência em grupos populares. Porto Alegre: Editora da UFRGS. 2004.

FORTES, Meyer. The significance of descent in Tale social structure. In: Time and Social Structure. London: University of London; New York: The Athlone Press/ Humanities Press.

FRYKMAN, Maja Povrzanovicå. Transnational perspective in ethnology: from 'ethnic' to 'diasporic' communities. In: FRYKMAN, Maja Povrzanovicå. Transnational Spaces: Disciplinary Perspectives. Malmö: University/IMER. 2004. p. 77-100. Disponível em: <www.bit.mah.se/muep. Acesso em:17 0ut 2014.

FORTES, M. 'Time and Social Structure: An Ashanti Case Study'. In: FORTES, M. (ed.). Social Structure: Studies. Oxford: University Press, 1949.

GLICK-SCHILLER, Nina. Diasporic Cosmopolitanism: Migrants, Sociabilities, and CityMaking. Disponível em: <https://www.academia.edu/4073876/Diasporic_Cosmopolitanism_ Migrants_Sociabilities_and_City-Making>. Acesso em: 21 out 2014.

GLUCKMAN, Max. Analysis of a social situation in modern Zululand. Bantu Studies. v. 14, n. 1, p. 1-30, 1940.

GODBOUT, Jacques T. Le don, la dette et l'identité. Paris: La Découverte, 2000. 
GOFFMAN, Ervin. Estigma: notas sobre a manipulação da identidade deteriorada. 4. ed. Rio de Janeiro: Guanabara, 1998.

GRAEBER, David. Debt - Updated and Expanded: The First 5,000 Years. Melville: House, 2014.

GRANOVETTER, M. S. La fuerza de los lazos débiles. Revisión de la teoría reticular. In: REQUENA SANTOS, F. Análisis de Redes Sociales. Orígenes, teorías y aplicaciones. Madrid: Centro de Investigaciones Sociales; Siglo XXI, 2003.

GREGORY, Chris. Gifts and Commodities. London: Academic Press, 1982.

Savage Money. The Anthropology and Politics of Commodity Exchange. Amsterdam: Harwood Academic, 1997.

GEERTZ, Clifford. The Bazaar Economy: Information and Search in Peasant Marketing. Papers and Proceedings of the Ninetieth Annual Meeting of the American Economic Association. The American Economic Review, v. 68, n. 2, p. 28-32, 1978.

GUYER, Jane. Introduction: The currency interface and its dynamics. In GUYER, Jane (Ed.). Money Matters. Instability, Values and Social Payments in the Modern History of West African Communities, Heinemann \& James Currey, 1995. p. 1-34.

GUYER, Jane. Wealth in People, Wealth in Things. Introduction. Journal of African History, v. 36, n.1, p. 83-90, 1995b.

HAMID, S. C. (Des) Integrando Refugiados: os processos do reassentamento de palestinos no Brasil. 2012. Tese (Doutorado) - Universidade de Brasília, Brasília, 2012.

HAMID, S. C. Entre a guerra e o gênero: memória e identidade de mulheres palestinas em Brasília. Tese (Doutorado) - Universidade de Brasília, Brasília, 2007.

HART, Keith. Heads or tails? Two sides of the coin. Man. New Series, v. 21, n. 4, p. 637656, 1986.

Money in the making of world society. In: Market and Society. The Great Transformation Today. Cambridge: Cambridge University Press: 2005a. p. 91-105. $16,2005 b$.

Money is always personal and impersonal. Anthropology Today, v. 23, n. 5, p. 12-

JARDIM, Denise Fagundes. As mulheres voam com seus maridos: a experiência da diáspora palestina e as relações de gênero. Horizontes Antropológicos, v. 15, n. 31, p. 189-217, 2009.

JARDIM, Denise Fagundes. Palestinos no extremo sul do Brasil: identidade étnica e os mecanismos sociais de produção da etnicidade - Chú́/RS. 2000. Tese de Doutorado. Universidade Federal do Rio de Janeiro/Museu Nacional, Rio de Janeiro, 2000.

JEAN-KLEIN, Iris. Into comitees, out of the house? American Ethnologist, v. 30, n. 4, p. 556-578, 2003. 
KANAANEH, R. A. Birthing the Nation: strategies of Palestinian women in Israel. California: University of California Press, 2002.

KEANE, Webb. From fetishism to sincerity: on agency, the speaking subject, and their historicity in the context of religious conversion. Comparative Studies in Society and History, v. 39, n. 4, p. 674-693, 1997.

LESSER, Jeff.. A negociação da identidade nacional: imigrantes, minorias e a luta pela etnicidade no Brasil. São Paulo: Unesp, 2001.

LÉVI-STRAUSS, Claude. Les structures élémentaires de la parenté. 2. ed. Paris: Mouton, 1967.

LINS, Wagner. A mão e a luva: judeus marroquinos em Israel e na Amazônia; similaridades e diferenças na construção de identidades étnicas. 2007. Tese (Doutorado) - Universidade de São Paulo, 2007.

MALINOWSKI, Bronislau. 1978. Introdução: tema, método e objetivo desta pesquisa. In: Os Argonautas do Pacífico Ocidental. São Paulo: Abril Cultural: 1978. P. 17-34. (Coleção Os Pensadores).

MARQUES, Ana Claudia D. R. 1999. Algumas faces de outros eus. Honra e patronagem na antropologia do Mediterrâneo. Mana, 5(1): 131-147.

MAUSS, Marcel. Ensaio sobre a dádiva. Forma e razão da troca nas sociedades arcaicas. In : MAUSS, Marcel. Sociologia e Antropologia. v. 2. São Paulo: Edusp, 1974.

MAYER, Phillip. Townsmen or Tribesmen? Oxford: Capetown, 1961.

MELLO, Pedro Paulo Thiago de. Mercadores de significados: O bazar como porta de entrada ao universo marroquino. Disponível em: <http://www.lemetro.ifcs.ufrj.br/ suq_de_sefrou_definitivo.pdf>. Acesso em: 02 out 2014.

MENDONÇA, Maurício Brilhante. O processo de decisão política e a Zona Franca de Manaus. Tese (Doutorado) - Fundação Getúlio Vargas, Rio de Janeiro, 2013.

MILGRAM, Stanley. The Small-World Problem. Psychology Today, v. 1, p. 62-67, Mayo, 1967.

MITCHELL, J. Clyde. Social Networks in Urban Situations. Manchester: Manchester University Press, 1969.

MONTENEGRO, S. Identidades muçulmanas no Brasil: entre o arabismo e a islamização. Lusotopie, p. 59-79, 2002.

MORGAN, Lewis Henry. Systems of consanguinity and affinity of the human family. Washington: Smithsonian Institution Press, 1870.

NUNES, Heliane Prudente. Historiografia da imigração árabe nos Estados Unidos e no Brasil: uma perspectiva comparativa. Textos de História, v. 4, n. 1, p. 149-180, 1996. 
OSMAN, Samira Adel. Problemáticas da imigração e do retorno na comunidade líbanobrasileira. Cadernos Ceru, v. 19, n. 1, p. 151-164, 2008.

PARRY, Jonathan; BLOCH, Marc. Introduction: Money and the morality of exchange. In: PARRY, Jonathan; BLOCH, Marc (Eds.). Money and the Morality of Exchange. New York: Cambridge University Press, 1989. viii. p. 91-32

PASTERNAK, B. Introduction to kinship and social organization. Englewood Cliffs, NJ: Prentice Hall, 1976.

PEIRANO, Mariza. Etnografia ou a teoria vivida. Revista Ponto Urbe, v. 2, n. 2, 2008. Antropologia política, ciência política e antropologia da política", in: Três Ensaios Breves. Série Antropologia, n. 231, p. 17-29. 1997. 15-26.

PETERS, R. Imigrantes palestinos, famílias árabes: um estudo antropológico sobre a recriação das tradições através das festas e rituais de casamento. 2006. Dissertação (Mestrado) Universidade Federal do Rio Grande do Sul, Porto Alegre, 2006.

PINHEIRO-MACHADO, Rosana. A ética confucionista e o espírito do capitalismo: narrativas sobre moral, harmonia e poupança na condenação do consumo conspícuo entre chineses ultramar. Horizontes antropológicos, v. 13. n. 28, p. 145-174, 2007.

PIZA, Douglas de Toledo. Um pouco da mundialização contada a partir da região da rua 25 de março: migrantes chineses e comércio. 2012. Tese (Doutorado) - Universidade de São Paulo, São Paulo, 2012.

POLANYI, Karl. The Self Regulating Market and the Fictitious Commodities: Land, Labour and Money. In George Dalton (Ed.). Primitive, Archaic and Modern Economies. Essays of Karl Polanyi. Boston: Beacon Press, 1968. p. 26-37.

PORTES, Alejandro; RUMBAUT, Ruben. Immigrant América-Aportraid. Califórnia: Berkeley, 1990. p. 1-56.

PORTUGAL, Sílvia. O que faz mover as redes sociais? Uma análise das normas e dos laços. Revista Crítica de Ciências Sociais, n. 79, p. 35-56. 2007.

PRATES, D. A. O fio de Ariadne: deslocamento, heterotopia e memória entre refugiados palestinos em Mogi das Cruzes, Brasil e Burj Al- Barajneh, Líbano. Dissertação (Mestrado) Universidade Federal Fluminense, Niterói, 2012.

RABINOW, P.; BIEHL, J. G. Antropologia da razão: ensaios de Paul Rabinow. Relume Dumará, 2002.

RABOSSI, Fernando. En la ruta de las confecciones. Revista latinoamericana deficiencias sociales, dossier la vida social de la economia, Crítica em Dessarrollo, 2008

RIBEIRO, Paula. Multiplicidade Étnica no Rio de Janeiro: um estudo sobre o 'Saara'. Revista Acervo, v. 10, n. 2, p. 199-212. 2011.

RIBEIRO, Gustavo Lins. El sistema mundial no-hegemónico y la globalización popular. Série Antropología, Brasília, v. 410, 2007. 
SASSEN, Saskia. The mobility of labor and capital. Nova York: Cambridge University Press, 1988.

SCHNEIDER, David M. Some muddles in the models, or, how the system really works." In: BANTON, M. (Ed.). The relevance of models for Social Anthropology. London: Tavistock, 1965. (A.S.A. Monograph I)..

SILVA, Kelly Cristiane da. A cooperação internacional como dádiva: algumas aproximações. Mana, v. 14, n. 1, p. 141-171, 2008.

Managing persons, things and rituals. Nation building as purification in TimorLeste. In: Co-Habitations and powers dynamics: land, exchange, governance. TimorLeste in contexto. International Conference. Lisboa: Museu do Oriente; Instituto de Ciências Sociais, 2015a.

The barlake war: marriage exchanges, colonial fantasies and the production of East Timorese people in the 1970s Dili. In: ROQUE, Ricardo; TRAUBE; Elizabeth (Ed.). Crossing histories and ethnographies. Ashagate, 2015b. (No prelo).

SILVA, Regina Coeli Machado e. Reordenação de identidade de imigrantes árabes em Foz do Iguaçu. Trab. Linguist. Apl., Campinas, v. 47, n. 2, Dec. 2008. Disponível em: <http:// www.scielo.br/scielo.php?script=sci_arttext\&pid=S0103-18132008000200006\&lng=en\& nrm=iso>. Acesso em: 13 Apr. 2015.

SOUZA, Márcio. A expressão amazonense. Do colonialismo ao neocolonialismo. São Paulo: Alfa e Ômega, 1978.

TROTTER, Robert T. Friends, relatives and relevant others: conducting ethnographic network studies. In: SCHENSUL, R. (org.). Mapping social networks, spatial data and hidden populations. Londres: Altamira, 1999.

WOLFE, Alvin. The Rise of Network Thinking in Anthropology. Social Networks, v. 1, p. 53-64, 1978.

WOORTMANN, Klaas. A etnologia (quase) esquecida de Bourdieu ou, o que fazer com heresias. Revista Brasileira de Ciências Sociais, v. 19, n. 56, 2004.

Com parente não se neguceia: o campesinato como ordem moral. Anuário

Antropológico, v. 87, p, 11-73, 1990. 